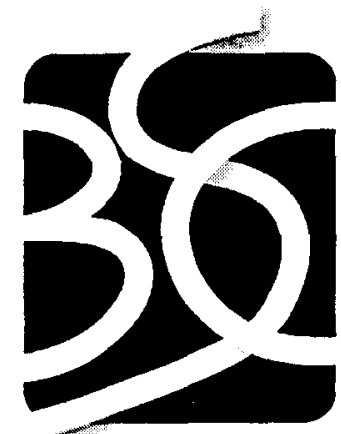

BECHTEL SAIC COMPANYLC
WBS: 1.2 .21

QA:N/A

Enclosure 1

September 17, 2001

MOL. 20020625.0071

\title{
Total System Performance Assessment - Analyses for Disposal of Commercial and DOE Waste Inventories at Yucca Mountain - Input to Final Environmental Impact Statement and Site Suitability Evaluation
}

Prepared for:

U.S. Department of Energy

Yucca Mountain Site CharacterizationOffice P.O. Box 30307

North Las Vegas, Nevada 89036-0307

Prepared by:

Bechtel SAIC Company, LLC

1180 Town Center Drive

Las Vegas, Nevada 89144

Under Contract Number

DE-AC08-01RW12101 
WBS: 1.2.21

QA:N/A

Total System Performance Assessment - Analyses for Disposal of Commercial and DOE Waste Inventories at Yucca Mountain - Input to Final Environmental Impact Statement and Site Suitability Evaluation

REV 00

September 17, 2001

Prepared for:

U.S. Department of Energy

Yucca Mountain Site Characterization Office

P.O. Box 30307

North Las Vegas, NV 89036-0307

Prepared by:

Bechtel SAIC Company, LLC

1180 Town Center Drive

Las Vegas, Nevada 89134

UNDER CONTRACT NUMBER

DE-AC08-01RW12101 


\section{CONTENTS}

1. PURPOSE 1

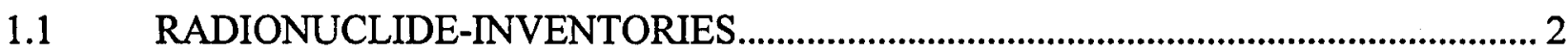

1.2 PERFORMANCE-ASSESSMENT CALCULATIONS …......................................... 3

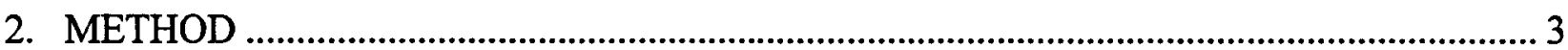

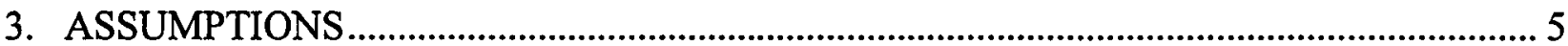

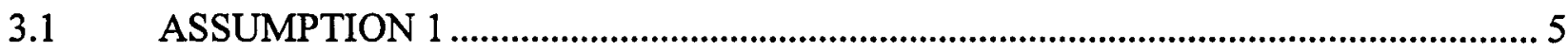

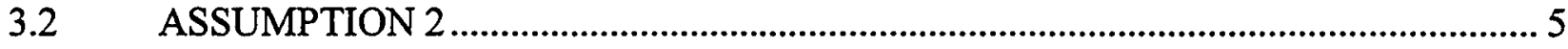

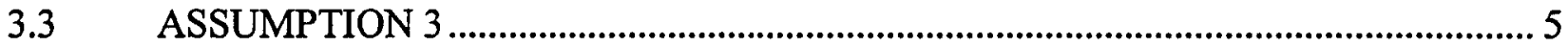

4. USE OF COMPUTER SOFTWARE

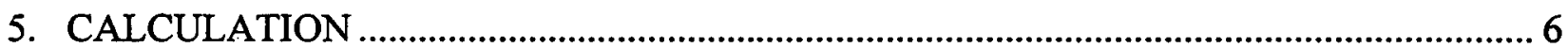

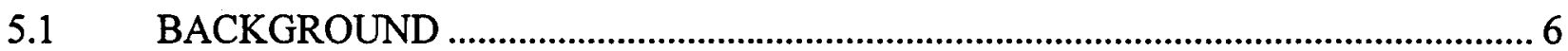

5.2 MODIFICATIONS TO THE TSPA-SR AND SSPA MODELS ................................. 6

5.2.1 Modifications to FEHM Particle Tracker Input and Output................................. 8

5.2.2 Estimation of the Thermal Profiles and Infiltration for the Lower Block ........... 8

5.2.3 The Saturated-Zone Breakthrough Curves ......................................................... 9

5.2.4 Modifications to the TSPA-SR Model and Early-Waste Package Failures....... 11

5.2.5 BDCFs for the 40 CFR Part 197 RMEI........................................................... 13

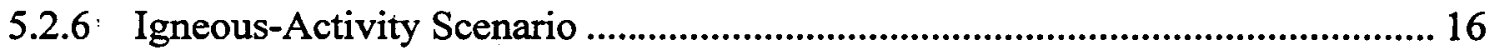

5.2.7 Human-Intrusion Scenario ..................................................................... 17

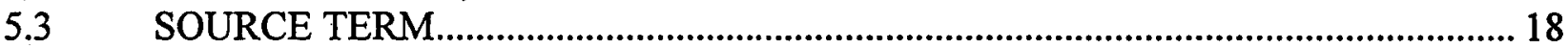

5.3.1 Radionuclide Inventories ..................................................................... 18

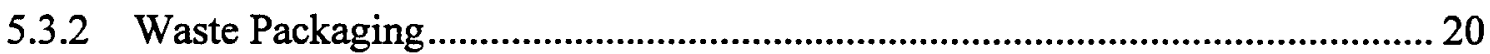

5.3.3 Waste Form Physical Properties ....................................................................... 20

5.3.4 Cladding Failure …......................................................................................... 20

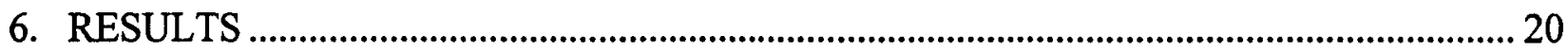

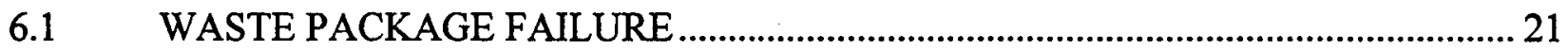

6.2 ANNUAL DOSE HISTORIES FOR THE 1,000,000- YEAR PERFORMANCE

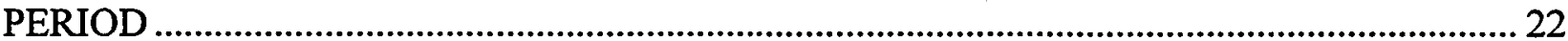

6.2.1 Annual Dose Due to the 70,000-MTHM Inventory ........................................ 22

6.2.2 Annual Dose Due for the Module 1 Expanded Inventory, High-Temperature

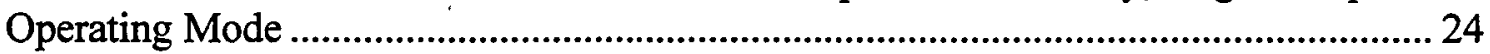

6.2.3 Annual Dose Due to the Module 2 Expanded Inventory, High-Temperature Operating Mode ......................................................................................................... 24 6.2.4 Comparison of Mean Annual Dose Due to the 70,000 MTHM Inventory, the Module 1 Expanded Inventory, and the Module 2 Expanded Inventory, HighTemperature Operating Mode.................................................................................... 24

6.3 ANNUAL DOSE FOR THE IGNEOUS-ACTIVITY SCENARIOS.............................. 24

6.3.1 Annual Dose Due to the High-Temperature Operating Mode............................. 25

6.3.2 Annual Dose Due to the Low-Temperature Operating Mode ........................... 25 
Analyses for Disposal of Commercial and DOE Waste Inventories at Yucca Mountain - Input to Final Environmental Impact Statement and Site Suitability Evaluation

\subsection{MEAN ANNUAL DOSE CALCULATED FOR THE HUMAN-INTRUSION}

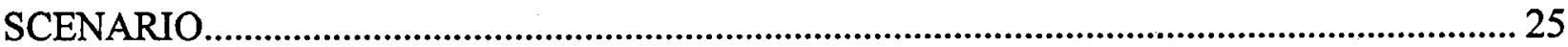

6.4.1 Annual Dose Due to Human Intrusion at 30,000 years after Repository Closure, High-Temperature Operating Mode ............................................................................. 25 6.4.2 Annual Dose Due to Human Intrusion at 100 years after Repository Closure, High-Temperature Operating Mode .................................................................................. 26

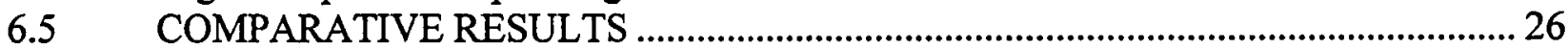

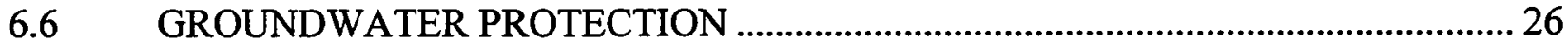

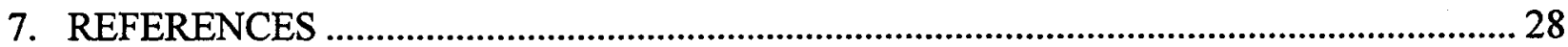

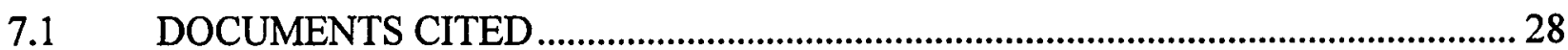

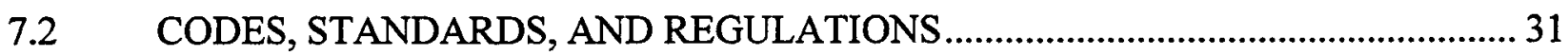



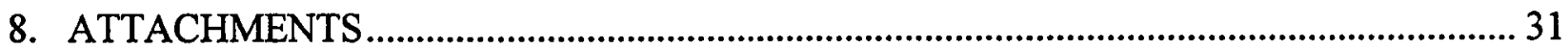


Analyses for Disposal of Commercial and DOE Waste Inventories at Yucca Mountain - Input to Final Environmental Impact Statement and Site Suitability Evaluation

\section{FIGURES}

$\underline{\text { Page }}$

5-1 Location of a Potential Yucca Mountain Repository.............................................................. 32

5-2 Approximate Configuration of a Potential Yucca Mountain Repository. ......................... 33

5-3 The Four Saturated-Zone Capture Regions in Relation to the Primary Repository Block for the 70,000-MTHM-Inventory Case ............................................................... 34

5-4 The Four Saturated-Zone Capture Regions in Relation to the Primary and Lower Repository Blocks for the Expanded-Inventory Case........................................................ 35

5-5 Outline of the Lower Block Showing the Locations of the 51 Particle-Tracking Nodes 36

5-6 Southernmost Boundary of the Controlled Area and the Accessible Environment........... 37

6-1 Waste-Package Failure Curves for the 70,000-MTHM Inventory and the $5^{\text {th }}$ and $95^{\text {th }}$ Percentiles, and the Mean and Median of these Simulations 38

6-2 Cladding-Failure Profile for the 70,000-MTHM-Inventory Case .................................... 39

6-3 Comparison Plot of the Mean Annual Dose versus Time for the TSPA-SR Case, the High Temperature Operating Mode and the LTOM for the 70,000-MTHM Inventory at the RMEI Location Downgradient from a Yucca Mountain Repository.

6-4 Total Mean Annual Dose and Mean Annual Dose for Radionuclides Contributing to Total Mean Annual Dose from the 300 Probabilistic Simulations for the HTOM for the 70,000-MTHM Inventory at the RMEI Location Downgradient from a Yucca Mountain Repository....

6-5 Annual Dose versus Time for 300 Probabilistic Simulations of the 70,000MTHM Inventory for the HTOM at the RMEI Location Downgradient from a Repository. The Figure Displays the Results for Each Simulation and the $5^{\text {th }}$ and $95^{\text {th }}$ Percentiles, and the Mean and Median of these Simulations.

6-6 Annual Dose versus Time for 300 Probabilistic Simulations of the 70,000MTHM Inventory for the LTOM at the RMEI Location Downgradient from a Repository. The Figure Displays the Results for Each Simulation and the $5^{\text {th }}$ and $95^{\text {th }}$ Percentiles, and the Mean and Median of these Simulations.

6-7 Annual Dose versus Time for 300 Probabilistic Simulations of the Module 1 Expanded Inventory for the HTOM at the RMEI Location Downgradient from a Repository. The Figure Displays the Results for Each Simulation and the $5^{\text {th }}$ and $95^{\text {th }}$ Percentiles, and the Mean and Median of these Simulations.

6-8 Annual Dose versus Time for 300 Probabilistic Simulations of the Module 2 Expanded Inventory for the HTOM at the RMEI Location Downgradient from a Repository. The Figure Displays the Results for Each Simulation and the $5^{\text {th }}$ and $95^{\text {th }}$ Percentiles, and the Mean and Median of these Simulations.

6-9 Comparison Plot of the Mean Annual Dose versus Time for HTOM for the 70,000-MTHM, Module 1 and Module 2 Inventories at the RMEI location Downgradient from a Repository. 
Analyses for Disposal of Commercial and DOE Waste Inventories at Yucca Mountain - Input to Final Environmental Impact Statement and Site Suitability Evaluation

\section{FIGURES}

6-10a Annual Dose versus Time for 500 of 5000 Probabilistic Simulations of the Igneous Activity Scenario, including both Intrusive and Eruptive Events, for the 70,000-MTHM Inventory for the HTOM at the RMEI Location Downgradient from a Repository. The Figure Displays the Results for Each Simulation and the $5^{\text {th }}$ and $95^{\text {th }}$ Percentiles, and the Mean and Median of these Simulations.

6-10b Mean Annual Dose versus Time for the Igneous Activity Scenario for the 70,000-MTHM Inventory for the HTOM at the RMEI Location Downgradient from a Repository. The Figure Displays the Mean Results for Both the Eruptive and Intrusive Events and the Sum of these Events as "Total Igneous Activity".

6-10c Mean Annual Dose versus Time for the Total Igneous Activity Scenario, which includes the Sum of the Igneous and Eruptive Events, for the TSPA-SR, HTOM, and the HTOM and LTOM for the 70,000-MTHM Inventory for this Letter Report at the RMEI Location Downgradient from a Repository.

6-11a Annual Dose versus Time for 500 of 5000 Probabilistic Simulations of the Igneous Activity Scenario, including both Intrusive and Eruptive Events, for the 70,000-MTHM Inventory for the LTOM at the RMEI Location Downgradient from a Repository. The Figure Displays the Results for Each Simulation and the $5^{\text {th }}$ and $95^{\text {th }}$ Percentiles, and the Mean and Median of these Simulations.

6-11b Mean Annual Dose versus Time for the Igneous Activity Scenario for the 70,000-MTHM Inventory for the LTOM at the RMEI Location Downgradient from a Repository. The Figure Displays the Mean Results for Both the Eruptive and Intrusive Events and the Sum of these Events as "Total Igneous Activity".

6-12 Annual Dose versus Time for the HTOM for the 30,000 year Human Intrusion Scenario for the 70,000-MTHM Inventory at the RMEI Location Downgradient from a Yucca Mountain Repository. The Figure Displays the Results of Each Simulation and the $5^{\text {th }}$ and $95^{\text {th }}$ Percentiles, and the Mean and Median of these Simulations

6-13 Annual Dose versus Time for 300 Probabilistic Simulations of the 100 year Human-Intrusion Scenario for the 70,000-MTHM Inventory for the HTOM at the RMEI Location Downgradient from a Repository. The Figure Displays the Results for Each Simulation and the $5^{\text {th }}$ and $95^{\text {th }}$ Percentiles, and the Mean and Median of these Simulations.

6-14 Comparison of the Mean Annual dose versus Time for the 70,000-MTHM Inventory (HTOM), the TSPA-SR Case and the SSPA Case (HTOM and LTOM) ........ 54

6-15 Comparison of the Annual Dose versus Time for the 70,000 MTHM Inventory (HTOM and LTOM) the Module 1 Inventory, (HTOM), the Module 2 Inventory, (HTOM), the Igneous-Activity Scenario, (HTOM and LTOM), the 30,000-yr and 100-yr Human-Intrusion Scenarios, (HTOM), and the TSPA-SR Case.

6-16 Comparison of the Annual Dose versus Time for the 70,000 MTHM Inventory, HTOM and LTOM, the Igneous-Activity Scenario, HTOM and LTOM, and the TSPA-SR Case, for the 100,000-year Performance Period. 


\section{FIGURES}

$\underline{\text { Page }}$

6-17 Mean Activity Concentrations of Gross Alpha Activity and Total Radium $\left({ }^{226} \mathrm{Ra}\right.$ plus ${ }^{228} \mathrm{Ra}$ ) for the 70,000 MTHM Inventory, HTOM. The Concentrations are Calculated for a Representative Volume of Groundwater of 3,000 acre-feet at the Accessible Environment, Which is the Same as the RMEI Location.

6-18 Mean Activity Concentrations of Gross Alpha Activity and Total Radium ${ }^{226} \mathrm{Ra}$ plus ${ }^{228} \mathrm{Ra}$ ) for the 70,000 MTHM Inventory, LTOM. The Concentrations are Calculated for a Representative Volume of Groundwater of 3,000 acre-feet at the Accessible Environment, Which is the Same as the RMEI Location.

6-19 Mean Dose to Critical Organs for ${ }^{99} \mathrm{Tc},{ }^{14} \mathrm{C}$, and ${ }^{129} \mathrm{I}$ for the $70,000 \mathrm{MTHM}$ Inventory, HTOM. The Concentrations are Calculated for a Representative Volume of Groundwater of 3,000 acre-feet at the Accessible Environment, Which is the Same as the RMEI Location.

6-20 Mean Dose to Critical Organs for ${ }^{99} \mathrm{Tc},{ }^{14} \mathrm{C}$, and ${ }^{129} \mathrm{I}$ for the $70,000 \mathrm{MTHM}$ Inventory, LTOM. The Concentrations are Calculated for a Representative Volume of Groundwater of 3,000 acre-feet at the Accessible Environment, Which is the Same as the RMEI Location. 
Analyses for Disposal of Commercial and DOE Waste Inventories at Yucca Mountain - Input to Final Environmental Impact Statement and Site Suitability Evaluation

\section{TABLES}

5-1 Comparison of the Average Values of the Dietary and Lifestyle Attributes for the Receptors.

5-2 Comparison of the BDCFs for the Receptors for the Groundwater Release and the Volcanic-Eruption Scenarios

5-3 Per-Package Radionuclide Inventories for the CSNF and Co-Disposal Waste Packages

5-4 Per-Package Radionuclide Inventories for the GTCC and SPAR Waste

6-1 Peak Dose and Year of Peak Dose by Scenario for Various Performance Periods:

(a) Peak Mean Annual Dose; (b) Peak $95^{\text {th }}$ Annual Dose.

6-2 Peak Mean Gross Alpha Activity by Scenario for Various Performance Periods............ 27

6-3 Peak Total Radium Concentration by Scenario for Various Performance Periods .......... 27

6-4 Maximum Dose to Critical Organs in 10,000 years for ${ }^{99} \mathrm{Tc},{ }^{14} \mathrm{C},{ }^{129} \mathrm{I}$, and Total of All Beta- and Photon-Emitting Radionuclides

II-1 Infiltration-rate bin Fractional Areas: 70,000-MTHM Inventory II-2

II-2a Infiltration-rate bin Fractional Areas: 70,000-MTHM Inventory, HTOM ..................... II-2

II-2b Infiltration-rate bin Fractional Areas: 70,000-MTHM Inventory, LTOM .................... II-2

II-3a Number of FEHM Nodes in Each Infiltration-rate bin: 70,000-MTHM Inventory ....... II-3

II-3b Adjusted Number of FEHM Nodes in Each Infiltration-rate bin: 70,000-MTHM Inventory ................................................................................................. II-3

II-4 Fraction of FEHM Nodes in Each Infiltration-rate bin: 70,000-MTHM Inventory ....... II-4

II-5 Number of FEHM Nodes in Each Infiltration-rate bin: Expanded Inventory ................ II-4

II-6 Fraction of FEHM Nodes in Each Infiltration-rate bin: Expanded Inventory ................. II-4

II-7a Proportional Fraction of the Repository Area in Each Infiltration-rate bin: Expanded Inventory, HTOM ................................................................................ II-5

11-7b Proportional Fraction of the Repository Area in Each Infiltration-rate bin: Expanded Inventory, LTOM................................................................................ II-5

II-8a Normalized Fraction of the Repository Area in Each Infiltration-rate bin: Expanded Inventory, HTOM ................................................................................. II-6

II-8b Normalized Fraction of the Repository Area in Each Infiltration-rate bin: Expanded Inventory, LTOM................................................................................. II-6

III-1 Volume of Inventory and Package Estimate.............................................................. III-2

III-2 GTCC Radionuclide Inventory ...................................................................... III-2

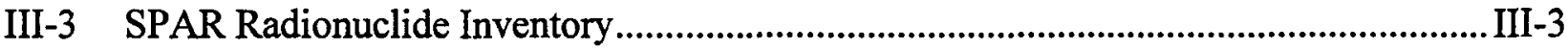

III-4 Naval SPAR Radionuclide Inventory ...............................................................III-4

III-5 Sum of GTCC and SPAR Radionuclide Inventories and Per-Package Inventory Estimate 
Analyses for Disposal of Commercial and DOE Waste Inventories at Yucca Mountain - Input to Final Environmental Impact Statement and Site Suitability Evaluation

\section{PURPOSE}

This Letter Report presents the results of calculations to assess long-term performance of commercial spent nuclear fuel (CSNF), U. S. Department of Energy (DOE) spent nuclear fuel (DSNF), high-level radioactive waste (HLW), and Greater Than Class C (GTCC) radioactive waste and DOE Special Performance Assessment Required (SPAR) radioactive waste at the potential Yucca Mountain repository in Nye County Nevada with respect to the 10,000-year performance period specified in 40 CFR Part 197.30 (66 FR 32074 [DIRS 155216], p. 32134) with regard to radiation-protection standards. The EPA Final Rule 40 CFR Part 197 has three separate standards, individual-protection, human-intrusion, and groundwater-protection standards, all with a compliance timeframe of 10,000 years. These calculations evaluate the dose to receptors for each of these standards. Further, this Letter Report includes the results of simulations to the 1,000,000-year performance period described in 40 CFR Part 197.35 (66 FR 32074 [DIRS 155216], p. 32135) which calls for the calculation of the peak dose to the Reasonably Maximally Exposed Individual (RMEI) that would occur after 10,000 years and within the period of geological stability. In accordance with TSPA-SR the "period of geologic stability" is from zero to $1,000,000$ years after repository closure. The calculations also present the $5^{\text {th }}$ and $95^{\text {th }}$ percentiles, and the mean and median of the set of probabilistic simulations used to evaluate various disposal scenarios.

These calculations have been conducted by the BSC Total System Performance Assessment Department in support of the Final Environmental Impact Statement (EIS) for a Geologic Repository for the Disposal of Spent Nuclear Fuel and High-Level Radioactive Waste at Yucca Mountain, Nye County, Nevada, and the Yucca Mountain Site Suitability Evaluation (SSE). The Nuclear Waste Policy Amendments Act of 1987 (NWPAA, Public Law 100-203 [DIRS 100016]) directs the DOE to evaluate the suitability of the Yucca Mountain site in southern Nevada as a potential site for development of a geologic repository for the disposal of spent nuclear fuel (SNF) and HLW. If the Secretary of Energy determines that the Yucca Mountain site is suitable, the Secretary may then recommend that the President approve the site for the development of a mined geologic repository.

The simulations conducted for this Letter Report calculate dose to the RMEI (as defined by 40 CFR Part 197.20 [DIRS 155216]) from the simulated release of radioactive materials from the potential Yucca Mountain repository to the accessible environment as specified in 40 CFR Part 197.21 (66 FR 32074 [DIRS 155216], p.32133). The RMEI is located in the accessible environment where the groundwater path of the highest concentration of the contaminant plume would cross the southernmost boundary of the controlled area of the potential repository (at a Latitude of $36^{\circ} 40^{\prime} 13.6661 "$ North). This location is approximately $18 \mathrm{~km}$ from within the potential repository footprint. The objective of this Letter Report is to update the results of the TSPA-SR and SSPA analyses and incorporate the requirements of 40 CFR Part 197 (66 FR 32074 [DIRS 155216]).

40 CFR Part 197.20 (66 FR 32074 [DIRS 155216], p. 32135) directed DOE to calculate the dose to the RMEI from releases from the undisturbed Yucca Mountain disposal system, and to include in the analysis, all potential pathways of radionuclide transport and exposure. Therefore, calculations in this Letter Report incorporate an igneous-activity scenario that includes a volcanic eruption. Under this scenario, the RMEI could receive part of the simulated total dose 
Analyses for Disposal of Commercial and DOE Waste Inventories at Yucca Mountain - Input to Final Environmental Impact Statement and Site Suitability Evaluation

from an air pathway contaminated during an eruptive event, as well as from the groundwater pathway.

The calculations included in this Letter Report were conducted following the Total System Performance Assessment for the Site Recommendation (TSPA-SR) (CRWMS M\&O 2000 [DIRS 153246], all) and the Supplemental Science and Performance Analyses (SSPA) (BSC 2001 [DIRS 154657], all). Process models included in the model configuration used in the calculations are generally consistent with the process models described in the TSPA-SR and implemented in the SSPA (CRWMS M\&O 2000 [DIRS 153246], all; BSC 2001 [DIRS 154657], all; BSC 2001 [DIRS 154659], Section 4.0, all); exceptions are described in Section 5 below.

The calculations include evaluation of annual dose histories for the 70,000-MTHM-inventory case used in TSPA-SR REV 00 ICN 01 and the SSPA, and two expanded-inventory cases, Module 1 and Module 2 (See Section 1.1 RADIONUCLIDE INVENTORIES immediately below) that ultimately include the total amount of commercial and DOE nuclear waste that could become available for disposal. The cases in these calculations utilized waste-package distributions consistent with the 70,000-MTHM-case thermal loading of approximately 56 MTHM per acre for the high-temperature operating mode (HTOM). In addition, the 70,000MTHM-case was evaluated under a thermal loading of approximately $45 \mathrm{MTHM} / \mathrm{acre}$, which is described as the low-temperature operating mode (LTOM).

This Letter Report was developed under Technical Work Plan TWP-MGR-MD-000016 REV 00 (BSC 2001 [DIRS 155906], all). This Technical Work Plan and the activity evaluation specified that this Letter Report was not to be developed per the YMP QA program and thus QARD requirements are not applicable.

\subsection{RADIONUCLIDE-INVENTORIES}

The performance-assessment calculations included in this Letter Report were performed for three separate radionuclide inventories that could be disposed at the potential Yucca Mountain repository. The 70,000-MTHM inventory is the limit for Yucca Mountain until a second repository becomes operational according to the Nuclear Waste Policy Amendments Act of 1987 (NWPAA, Public Law 100-203 [DIRS 100016]). The other two cases consider two radionuclide inventories that would require the expansion of the repository to include the complete inventory of commercial and DOE radioactive waste. The cases, as directed by DOE in the Technical Work Plan TWP-MGR-MD-000016 for this activity (BSC 2001 [DIRS 155906], all) are described as follows:

- 70,000-MTHM-Inventory Case: The 70,000-MTHM-Inventory Case is comprised of 63,000 MTHM of CSNF, 2,333 MTHM of DSNF, and 4,667 MTHM of HLW.

- Expanded-Inventory Case - Module 1: Module 1 includes the CSNF and DSNF waste included in the 70,000-MTHM case plus all remaining CSNF, DSNF, and HLW. The Module 1 inventory consists of approximately 105,000 MTHM of CSNF, 2,500 MTHM of DSNF, and 11,500 MTHM of HLW. 
Analyses for Disposal of Commercial and DOE Waste Inventories at Yucca Mountain - Input to Final Environmental Impact Statement and Site Suitability Evaluation

- Expanded-Inventory Case - Module 2: Module 2 includes all the CSNF, DSNF, and HLW in Module 1 plus approximately $2,100 \mathrm{~m}^{3}$ of GTCC waste and $4,000 \mathrm{~m}^{3} \mathrm{DOE}$ SPAR waste.

\subsection{PERFORMANCE-ASSESSMENT CALCULATIONS}

The set of calculations included in this Letter Report cover both the 10,000-and 1,000,000-year performance periods specified in 40 CFR Part 197.30 and 197.35 (66 32074 [DIRS 155216] p. 32134 and 32135) and the Technical Work Plan TWP-MGR-MD-000016 for this activity (BSC 2001 [DIRS 155906], all). The calculations comprise the following scenarios:

- 70,000-MTHM Inventory, HTOM

- 70,000-MTHM Inventory, LTOM

- Expanded-inventory Case, Module 1, HTOM

- Expanded-inventory Case, Module 2, HTOM

- Igneous-Activity Scenario including both the igneous-intrusion and volcanic-eruption scenarios, 70,000-MTHM Inventory, HTOM

- Igneous-Activity Scenario including both the igneous-intrusion and volcanic-eruption scenarios, 70,000-MTHM Inventory, LTOM

- Human-Intrusion Scenario, 70,000-MTHM Inventory, 30,000 years postclosure, HTOM

- Human-Intrusion Scenario, 70,000-MTHM Inventory, 100 years postclosure, HTOM

These performance-assessment calculations primarily address only the long-term impacts from radionuclides released from the potential repository. All these scenarios calculate dose due to the groundwater pathway to the location of the RMEI. The igneous-activity scenarios also include an atmospheric-transport pathway due to a volcanic-eruption.

\section{METHOD}

The calculations presented in this Letter Report were performed using the numerical code GoldSim, Version 7.17.200 (BSC 2001, GoldSim V7.17.200 10344-7.17.200-00. URN 0901 [DIRS 155182]). The GoldSim calculations were performed for the conceptual/process modeling of the potential Yucca Mountain repository described in TSPA-SR Rev 00, ICN 01 (CRWMS M\&O 2000 [DIRS 153246]) and expanded upon in the SSPA (BSC 2001, Volume 1, [DIRS 154657]; BSC 2001, Volume 2, [DIRS 154569]). The Technical Work Plan TWP-MGRMD-000016 REV 00 (BSC 2001 [DIRS not yet available]) indicates that a primary task of this Letter Report is to incorporate technical requirements of 40 CFR Part 197 (66 FR 32074 [DIRS 155216]) into the model configuration used to simulate repository performance and to present results that document any difference in dose as compared to TSPA-SR and SSPA. The results of these calculations are presented in Section 6. 
Analyses for Disposal of Commercial and DOE Waste Inventories at Yucca Mountain - Input to Final Environmental Impact Statement and Site Suitability Evaluation

The TSPA calculations for both the TSPA-SR, the SSPA, and the calculations described in this Letter Report were performed within a probabilistic framework combining the most likely ranges of behavior for the various component models, processes, and corresponding parameters included in the overall conceptual/process model describing the performance of the repository. GoldSim integrates the sub-system models using a Monte-Carlo simulation-based methodology to create multiple random combinations of the uncertain variables, and computes the probabilistic performance of the entire waste-disposal system in terms of mean annual dose to receptors. The GoldSim software calculates radionuclide release and radiological dose (the annual committed effective dose equivalent (CEDE) as defined in 40 CFR Part 197.2 [DIRS 155216], p. 32132) from individual radionuclides and the total annual dose due to all radionuclides released from the repository from failed waste packages. In this Letter Report the CEDE will be referred to as the annual dose. GoldSim calculates the total annual dose for 300 realizations of the model configuration using randomly selected values of distributed parameters for each realization. The calculation results are available in two main forms: (1) probability distributions for peak dose to the RMEI, and (2) time histories of annual dose to the RMEI.

The recently promulgated U.S. Environmental Protection Agency Final Rule 40 CFR Part 197 (66 FR 32074 [DIRS 155216]) stipulates that the performance assessment of the potential Yucca Mountain repository include an estimate of dose to the RMEI. The Rule further states that this assessment provide, for 10,000 years, the RMEI CEDE (40 CFR Parts 197.20 and 25 [DIRS 155216], $\mathrm{p}$ 32134). For the purposes of an EIS, the performance assessment must calculate the peak dose that would occur within the period of geologic stability (40 CFR Part 19735 (66 FR 32074 [DIRS 155216], p. 32135)). The peak dose is projected to be within 1,000,000 years.

The performance-assessment methodology used for the calculations presented in this Letter Report draws upon the extensive analyses carried out in support of the TSPA-SR (CRWMS M\&O 2000 [DIRS 153246], all) and in the SSPA Volume 1 and Volume 2 (BSC 2001 [DIRS 154657], all, and BSC 2001 [DIRS 154659], all). Only those model components and related parameters that were modified to account for the scenarios considered in addition to those used in the TSPA-SR or the SSPA are described in this Letter Report. In addition, the model configuration used for the calculations presented in this Letter Report was modified to conform to the recently promulgated U.S. Environmental Protection Agency Final Rule. The Final Rule provides the criteria to be used in determining the RMEI location (40 CFR Part 197.12 and Part 197.21 [DIRS 155216], p. 32133 and 32134), the other criteria of the RMEI (which were applied in the calculation of biosphere dose-conversion factors (BDCFs)), and the groundwater protection standard, including the representative volume to be used for the calculation of gross alpha activity, total radium activity, and whole-body dose (40 CFR Part 197.30 [DIRS 155216], Table 1, p. 32134). These model modifications are described below in Section 5.2.

This Letter Report considers inventories in addition to those described in the TSPA-SR and the SSPA for the 70,000 MTHM inventory. The calculations in this Letter Report include the 70,000 MTHM-inventory case under both the HTOM and LTOM, the expanded-inventory cases under the HTOM, and the following scenarios:

- The human-intrusion scenario (CRWMS M\&O 2000 [DIRS 153246], Section 4.4, p. 4-25 to 4-32) which considers an "intruder" drilling a land-surface borehole using a drilling apparatus (under the common techniques and practices that are currently employed in exploratory drilling for groundwater in the region around Yucca Mountain), drills directly 
Analyses for Disposal of Commercial and DOE Waste Inventories at Yucca Mountain - Input to Final Environmental Impact Statement and Site Suitability Evaluation

through an intact or a degraded waste package, and subsequently into the uppermost aquifer underlying Yucca Mountain. The "intrusion" then causes the subsequent compromise and release of the contaminated waste in the penetrated waste package. Two human-intrusion scenarios were simulated for a one-million-year performance period: one intrusion at 30,000 years and the other intrusion at 100 years after repository closure.

- The igneous-activity scenario, contains a volcanic-eruption, which includes exposure as a result of atmospheric-transport and deposition on the ground, and an igneous-intrusion groundwater-transport scenario (BSC 2001. [DIRS 154657], Section 14.2.1, p. 14-5). In the volcanic-eruption scenario (CRWMS M\&O 2000 [DIRS 153246], Section 3.10, p3-187 to 3216), a dike (or dikes) intersects one or more repository drifts and compromises all waste packages in the affected drifts. Then, an eruptive conduit of an associated volcano intersects waste packages in its path. Waste packages in the path of the conduit are sufficiently damaged that they provide no further protection, and the waste in the packages is entrained in the eruption and subject to atmospheric transport. In the igneous-intrusion groundwatertransport scenario, the analysis calculated releases caused by a dike (or dikes) intersecting emplacement drifts, causing varying degrees of waste-package damage.

\section{ASSUMPTIONS}

\subsection{ASSUMPTION 1}

The 70,000-MTHM-case model configuration for the calculations in this Letter Report is based on the SSPA model configuration (BSC 2001 [DIRS 154657], all), which differs from the TSPASR model (CRWMS M\&O 2000 [DIRS 153246], all). The model used for the calculations in Sections 6.0 below includes the modifications from the SSPA and TSPA-SR models as described below in Section 5. Other assumptions incorporated into the SSPA model are documented in the SSPA Volume 2 (BSC 2001 [DIRS 154659], Section 2, all). The key differences between the SSPA and the model configuration used in the calculations presented in this Letter Report are described in Section 5.2.

\subsection{ASSUMPTION 2}

The radionuclide inventories used in the calculations in Section 6.0 are those developed in the Inventory Abstraction (BSC 2001 [DIRS 154841], Table 36, p.38). The per-package inventories for the CSNF, and co-disposal waste packages are the same as those used in the TSPA-SR (CRWMS M\&O 2000 [153246], Section 3.5.1, p. 3-94 to 3-100) but the DSNF inventory does not include the U.S. Navy spent nuclear fuel. The Navy spent nuclear fuel is conservatively represented by commercial spent nuclear fuel (BSC 2001 [DIRS 152059], all; DOE 2001 [DIRS 153849], Section 4.2.6.3.9, p. 4-257). The per-package inventories used for the GTCC and SPAR calculations use the inventory presented in Attachment III of this Letter Report.

\subsection{ASSUMPTION 3}

This Letter Report provides calculations which incorporate information and requirements in the recently promulgated EPA Final Rule 40 CFR Part 197, into the existing modeling runs to document any difference in dose. This Letter Report will not produce either qualified or baseline 
Analyses for Disposal of Commercial and DOE Waste Inventories at Yucca Mountain - Input to Final Environmental Impact Statement and Site Suitability Evaluation

outputs. If needed for future baseline, the outputs will be developed in a technical product using qualified software and submitted to the Technical Data Management System

\section{USE OF COMPUTER SOFTWARE}

The calculations described in this Letter Report were performed using the numerical code GoldSim, Version 7.17.200. (BSC, 2001, GoldSim V7.17.200 10344-7.17.200-00. URN 0901 [DIRS 155182]). GoldSim was developed by Golder Associates as an update to the baseline software, RIP v.5.19.01 (Golder Associates 1998 [DIRS 151395], Computer Software Configuration Item (CSCI) 30055 V5.19.01). GoldSim is a Windows-based program that is computationally similar to RIP v.5.19.01 which was used for TSPA calculations for the Viability Assessment (DOE 1998, Volume 3 [DIRS 100550], p. 2-29). GoldSim is designed so that probabilistic simulations can be conducted and represented graphically. Although not currently qualified in accordance with AP-SI.1Q, Software Management, GoldSim Version 7.17.200 (STN: 10344-7.17.200-00 [DIRS 155182]) is used for this application and used within an acceptable specified range (See Assumption 3).

\section{CALCULATION}

\subsection{BACKGROUND}

The scope of the calculations presented in this Letter Report includes evaluation of long-term performance after the eventual closure of a Yucca Mountain Repository (Figure 5-1). In particular, these calculations focus on a Yucca Mountain repository for the disposal of 70,000 MTHM of nuclear material allowed by the amended NWPA. The calculations were performed in a manner consistent with the specifications of the EPA standard regarding a repository at Yucca Mountain found in 40 CFR Part 197 (66 FR 32074 [DIRS 155216], pp. 32132 - 32135) with respect to potential public-health impacts. The calculations also address the potential expansion of a repository to include additional mined areas needed for the expanded-inventory cases. The Module 2 inventory includes all of the Module 1 inventory plus the total projected inventory of GTCC commercial low-level radioactive waste and DOE SPAR low-level radioactive waste.

\subsection{MODIFICATIONS TO THE TSPA-SR AND SSPA MODELS}

This Letter Report builds on the TSPA-SR (CRWMS M\&O 2000 [DIRS 153246]) and SSPA (BSC 2001 [DIRS 154657]) modeling of the 70,000-MTHM-case repository configuration. Because the EIS will also evaluate the possible consequences of ultimately including the entire CSNF, DSNF, and HLW waste inventories, an expanded repository area was also considered.

The change from the TSPA-SR waste inventory and repository area to a calculation of the performance of an expanded repository includes addition of the Lower Block, shown on Figure $5-2$, in the calculations. The TSPA-SR and SSPA reports relied on a detailed analysis of only the Primary Block shown on Figure 5-2.

The GoldSim numerical code simulates transport of radionuclides from the repository, through the unsaturated zone (UZ), and through the saturated zone (SZ) to the accessible environment. The different process models included in the GoldSim code are fully described and documented 
Analyses for Disposal of Commercial and DOE Waste Inventories at Yucca Mountain - Input to Final Environmental Impact Statement and Site Suitability Evaluation

in the TSPA-SR (CRWMS M\&O 2001 [DIRS 153246], all). The UZ-transport release nodes and SZ-transport capture areas for the 70,000 MTHM inventory in the TSPA-SR and SSPA models were modified for the expanded-inventory cases to include the Lower Block emplacement area for the Module 1 and Module 2 inventories. (See Section 5.2.1 and Attachment II of this Letter Report.)

The GoldSim model configuration used for the SSPA was modified to conform to the recently published EPA Final Rule 40 CFR Part 197 (66 FR 32074 [DIRS 155216], p. 32132 to 32135 ). The model also assesses the performance of additional radionuclide inventories and performance scenarios. The following Sections 5.2.1 through 5.2.7 describe the modifications to the TSPASR and SSPA models. The model configuration for the calculations presented in the Letter Report differs from these earlier TSPA models in the following areas:

- The model used for the calculations in this Letter Report used BDCFs based on the RMEI defined in 40 CFR Part 197.21 (66 FR 32074 [DIRS 155216], p. 32134). The models used in the TSPA-SR and SSPA used different BDCFs based on the Average Member of the Critical Group (AMCG) in the proposed 10 CFR PART 63.115 9([DIRS 107770], p. 8645 to 8646).

- The length of the SZ simulated in the model configuration for the calculations in this Letter Report extends from within the repository footprint to the boundary between the controlled area and the accessible environment specified in 40 CFR Part 197.12 (66 FR 32074 [DIRS 155216], p. 32132 to 32133 ), namely, Latitude $36^{\circ} 40^{\prime} 13.6661^{\prime \prime}$ North, above the highest concentration of radionuclides in the plume of contamination. The RMEI is assumed to reside at this location in the accessible environment. The latitude at this location is the latitude at the southwestern corner of the Nevada Test Site.

- Groundwater protection was assessed using an annual representative volume of 3,000 acre$\mathrm{ft} / \mathrm{yr}$, of groundwater as specified at 40 CFR Part 197, to calculate the total alpha activity, the total radium concentration, and the whole-body dose. To calculate all other concentrations not included in the groundwater-protection standard, the water usage was assigned in the same probabilistic manner as used in the TSPA-SR (CRWMS M\&O 2000 [DIRS 153246] Section 3.9.2.4, p. 3-184) and the SSPA (BSC 2001 [DIRS 154567], Section 13.3.5, p. 13-41 to $13-44)$.

- The waste inventories used for the calculations in this Letter Report are presented in the Inventory Abstraction Analysis Model Report (AMR) (BSC 2001 [DIRS 154841], Table 36, p. 38). The difference between this inventory and that used in the TSPA-SR and SSPA reports is that, for the calculations in this Letter Report, the DSNF inventory does not include the U.S. Navy spent nuclear fuel. The Navy spent nuclear fuel is conservatively represented by commercial spent nuclear fuel (BSC 2001 [DIRS 152059], all; DOE 2001 [DIRS 153849], Section 4.2.6.3.9, p. 4-257).

- Waste-package corrosion for the calculations in this Letter Report is due to general corrosion independent of temperature as was true for TSPA-SR. The SSPA calculations included temperature-dependent waste-package corrosion. 
Analyses for Disposal of Commercial and DOE Waste Inventories at Yucca Mountain - Input to Final Environmental Impact Statement and Site Suitability Evaluation

- The process-level LTOM thermal-hydrologic results for this Letter Report were corrected from those presented in the SSPA to include radiation connections in the Nonisothermal Unsaturated-saturated Flow and Transport (NUFT) model (Nitao 1998 [DIRS 100474], all).

\subsubsection{Modifications to FEHM Particle Tracker Input and Output}

The UZ flow-and-transport modeling in the TSPA-SR, SSPA, and this Letter Report is conducted with the Finite Element Heat and Mass (FEHM) model (Zyvoloski et al. 1999 [DIRS 107889], all). The movement of fluid and radionuclides released from the waste packages is followed through the UZ by means of a particle-tracking algorithm in the TSPA-SR and SSPA process models (CRWMS M\&O 2000 [DIRS 153246], p.2-27) and (BSC 2001 [DIRS 154657], Section 11, all). The particle-tracking files used in the TSPA-SR were modified for the expanded-inventory case to allow the FEHM UZ input regions to correspond to the Lower Block area used for the simulations. The interface file in GoldSim was modified for this case by changing the FEHM nodes used for transport from the Primary Block as considered in the TSPA-SR, the SSPA, and the 70,000 MTHM inventory. The calculations presented in this Letter Report also include the Lower Block of a potential repository, which would also be used for input of mass from an expanded-repository area. The FEHM nodes were chosen to correspond to the Lower Block repository coordinates because of the changes to the regions from which mass is captured coming out of the FEHM model (CRWMS M\&O 2000 [DIRS 155393], Attachments II and III, all). Capture regions at the surface of the saturated zone accumulate water and mass released from the repository that has been transported through the UZ. The capture regions for the Primary Block are shown in Figure 5-3. These capture regions were modified to ensure all the mass was captured and to distribute the mass to the $\mathrm{SZ}$ capture regions including release from the Lower Block. Figure 5-4 shows the capture regions used for the expanded-inventory cases.

The repository nodes were extracted based on the information and representation of the repository configuration provided by the following documents and data as described in EIS Performance-Assessment Analyses for Disposal of Commercial and DOE Waste Inventories at Yucca Mountain (CRWMS M\&O 2000 [DIRS 155393], Attachment II, all): (1) CRWMS M\&O (2000 [DIRS 150941]), Figure 4-14), and (2) Emplacement Drift Coordinates - Expanded Waste Inventory Layout. The drifts in the Lower Block were first grouped into larger groups based on similar elevations. Then, the boundary coordinates of the larger groups were used to define rectangular regions. The Software Routine repocoordl.f (Version 1.0) (CRWMS M\&O 2000, [DIRS 155393], Attachment II, all) was used to extract FEHM nodes within the rectangular region. The extracted nodes were then plotted using SigmaPlot (Version 4.01, a commercial, graphics software) and nodes that fall beyond the defined drift region were removed from the repository node list. Use of Software Routine repocoordl. $f$ (Version 1.0) in the calculations in this Letter Report is documented in (CRWMS M\&O 2000 [DIRS 155393], Attachment II, all).

\subsubsection{Estimation of the Thermal Profiles and Infiltration for the Lower Block}

The TSPA-SR and SSPA models used to assess repository performance utilized thermohydrologic modeling to estimate infiltration from land surface to the repository horizon. Infiltration water is the principal cause of waste-package corrosion and the main agent for waste transport. The TSPA-SR and SSPA model conceptualizations for the Yucca Mountain repository consider waste forms in discrete areal regions of the repository as source terms for 
Analyses for Disposal of Commercial and DOE Waste Inventories at Yucca Mountain - Input to Final Environmental Impact Statement and Site Suitability Evaluation

flow and transport from the repository to the SZ. The GoldSim conceptualization for TSPA-SR considers the repository block, referred to as the "Primary Block", to be comprised of four source regions (Figure 5-3). The four regions are covered by the Yucca Mountain multiscale thermohydrologic model and its abstraction which was used to develop the thermodynamicenvironment time histories at different potential waste-package locations distributed throughout the Primary Block (CRWMS M\&O 2000 [DIRS 139610], Section 6.6, all and CRWMS M\&O 2001 [DIRS 154594], Section 6.3, all). These time-histories for the HTOM were used in both the TSPA-SR and the SSPA.

The expanded-inventory calculations for this Letter Report use two additional areas for disposal; up to an additional $\sim 218$ acres of the Primary Block (The design of the Primary Block includes area not used in the 70,000 MTHM-inventory scenario, HTOM, \{CRWMS M\&O 2000 [DIRS 150941], Figure 4-14\}); and up to a 408-acre "Lower Block", which lies to the east of the Primary Block (Figure 5-2). For the expanded inventory, source-region 2 was expanded to the east so that its areal extent would cover the Lower Block (Figure 5.4) (CRWMS M\&O 2000 [DIRS 155393], Section 5.2.2, p. 11-12).

The following methodology was used to develop thermal histories for waste packages emplaced in the Lower Block. The thermal response from the multi-scale thermohydrologic model (CRWMS M\&O 2000 [DIRS 149862] all) is correlated to the distance from the edge of the repository. Further, seepage into the drift is a function of the local infiltration flux. Therefore, the location and estimated infiltration flux were used to select analogous Primary-Block thermohydrologic responses for application to comparable locations in the Lower Block. Thus, the Primary Block thermohydrologic data was extended to the 51 Lower-Block elements shown on Figure 5-5. Details of the extension of this method to the 51 nodes is provided in CRWMS M\&O (2000 [DIRS 155393] Attachment II, p. II-2 to II-5) and the estimation of Lower-Block infiltration seepage is provided in CRWMS M\&O (2000 [DIRS 155393] Attachment III, p. III-2 to III-19). The glacial-transition climate infiltration rate for the 51 elements was estimated from the site-scale hydrologic model (Bodvarsson et. al. 1997 [DIRS 100103]). For each of the 51 Lower-Block elements, the GoldSim software code was configured with thermal-history data sets from the site multi-scale thermohydrologic model (CRWMS M\&O 2000 [DIRS 139610], Section 6.6, all, and its abstractions CRWMS M\&O 2001 [DIRS 154594], Section 6.3, all) based on similar infiltration and proximity to the edge of the repository as the analogous Primary-Block locations. Using these data, the infiltration categories, or bins, for the waste packages associated with the Expanded-Inventory case were established as described in EIS Performance-Assessment Analyses for Disposal of Commercial and DOE Waste Inventories at Yucca Mountain (CRWMS M\&O 2000 [DIRS 155393], p. IV-2 to IV-4). The use of thermal profiles in estimating infiltration to the repository blocks is described in detail in EIS Performance-Assessment Analyses for Disposal of Commercial and DOE Waste Inventories at Yucca Mountain (CRWMS M\&O 2000 [DIRS 155393], p. III-2 to III-19). Attachment II of this Letter Report describes the calculation of the fractional Lower-Block repository areas corresponding to the infiltration bins.

\subsubsection{The Saturated-Zone Breakthrough Curves}

Transport in the SZ beneath the repository is the main route for groundwater transport of contaminants leached from the repository. The radioactive contaminants move through the $\mathrm{SZ}$ to the accessible environment. The accessible environment is defined as any area outside of the controlled area (40 CFR Part 197.12; 66 FR 32074 [DIRS 155216], p. 32132). The EPA Final 
Analyses for Disposal of Commercial and DOE Waste Inventories at Yucca Mountain - Input to Final Environmental Impact Statement and Site Suitability Evaluation

Rule, 40 CFR Part 197.12 (66 FR 32074 [DIRS 155216], p. 32133), specifies the following elements of the controlled area:

(1) The surface area, identified by passive institutional controls, that encompasses no more than 300 square kilometers. It must not extend farther:

(a) south than $36^{\circ} 40^{\prime} 13.6661 "$ North Latitude, in the predominant direction of ground water flow; and

(b) than five kilometers from the repository footprint in any other direction; and

(2) The subsurface underlying the surface area.

The location where the RMEI resides, which is also where groundwater protection will be analyzed, is the point above the highest concentration of radionuclides in the simulated plume of SZ contamination where the plume crosses the southernmost boundary of the controlled area (at a Latitude of $36^{\circ} 40^{\prime} 13.6661^{\prime \prime}$ North) and reaches the accessible environment. For this analysis, DOE has selected the southern boundary of the controlled area and the location of the RMEI to be at the limit discussed above, which is approximately $18 \mathrm{~km}$ (11 miles) from within the potential repository, compared to the corresponding distance of approximately $20 \mathrm{~km}$ (12 miles) used in the SZ transport modeling for TSPA-SR and the SSPA, as shown in Figure 5-6. To evaluate long-term performance with respect to the standard set in the EPA Final Rule 40 CFR Part 197.12 (66FR32074 [DIRS 155216]), additional SZ breakthrough curves, which describe the time-related arrivals of radionuclides at the RMEI location, were calculated for all radionuclides used in the calculations in this Letter Report. The SZ breakthrough curves were used in the analyses to simulate radionuclide transport from the water table beneath the potential repository to the RMEI location. It should be noted that, depending on the subsurface layout of a repository, the distance to the RMEI location from any point in the subsurface layout could be more or less than $18 \mathrm{~km}$. For convenience and consistency with other documents, the RMEI location will be consistently discussed as being approximately $18 \mathrm{~km}$ from the potential repository.

To generate the SZ breakthrough curves used in the calculations in this Letter Report, 100 realizations of the SZ site-scale flow-and-transport model were performed as described in the SZ process model (CRWMS M\&O 2000 [DIRS 139440], Sections 6.2 and 6.3, all) to generate SZ breakthrough curves at the RMEI location. Other stochastic parameters for the SZ simulations use the same values as were used in the SZ breakthrough curves for the SSPA analysis (BSC 2001 [DIRS 154659], Section 3.2.10, all). The simulated radionuclide breakthrough curves at the RMEI location (approximately $18 \mathrm{~km}$ ) exhibited shorter transport times than those at $20 \mathrm{~km}$ as presented in SSPA analysis (BSC 2001 [DIRS 154657], Section 13.2.1.3, all) on a realizationby-realization basis. In particular, those radionuclides that may have significantly greater sorption in the alluvium than in the volcanic units (e.g., Np-237) exhibit shorter transport times to the RMEI location in this analysis relative to the 20-km location used in TSPA-SR, SSPA, and the draft EIS. This result is related to the fact that the RMEI location in this analysis results in a decrease in the length of transport through the alluvium relative to the transport path to the 20$\mathrm{km}$ location. 
Analyses for Disposal of Commercial and DOE Waste Inventories at Yucca Mountain - Input to Final Environmental Impact Statement and Site Suitability Evaluation

The approach used for simulations of groundwater flow and radionuclide transport in the SZ used in this Letter Report is the same as the approach used in TSPA-SR. The SZ site-scale flowand-transport model has been used to simulate the unit radionuclide mass-breakthrough curves for radionuclides of concern to the site recommendation (SR) at the RMEI location, approximately $18 \mathrm{~km}$ downgradient from the repository. In the model configuration for the calculations for this Letter Report, these SZ breakthrough curves are coupled with the other components of the system (mass flux and representative volume or water usage) using the convolution-integral method in the same manner as described and implemented in the GoldSim program for TSPA-SR and the SSPA (CRWMS M\&O 2000 [DIRS 153246], Section 2.2.2, all) and (BSC 2001 [DIRS 154657], Section 3.2.10, all). In addition, the simulation of radionuclide decay chains and the transport of daughter products in the SZ system is performed using a onedimensional model directly in the GoldSim numerical code.

In the SZ model, the capture regions that accumulate flow and mass at the base of the UZ become the source regions for the SZ model. The four radionuclide source regions (Figures 5-3 and 5-4) in the SZ that were defined for the 70,000-MTHM case of the TSPA-SR (CRWMS $\mathrm{M} \& O 2000$ [DIRS 153246], Section 3.8.2.2, all and Figure 3.8-14, p. F3-117) are used in the calculations in this Letter Report. For the expanded-repository case, radionuclide mass originating from the Lower Block of the repository is applied to source region number 2 in the $\mathrm{SZ}$ transport module. The Lower Block of the expanded repository extends farther to the east than the SZ source region number 2 for the TSPA-SR base case. However, applying the radionuclide mass from the Lower Block to this source region constitutes a conservative approximation of transport in the SZ. Lower permeability rocks of the upper volcanic confining unit exist at the water table in the area immediately to the east of SZ source region number 2, which would result in slower initial advective groundwater velocity for radionuclide transport in this area. Preliminary results of radionuclide-transport simulations with the SZ site-scale flowand-transport model confirm that radionuclide transport times in the $\mathrm{SZ}$ from the area below the expanded-repository Lower Block are longer than the transport times from SZ source region number 2 in the 70,000-MTHM case considered in this Letter Report.

\subsubsection{Modifications to the TSPA-SR Model and Early-Waste Package Failures}

\subsubsection{Modifications to the Waste Package Degradation Model}

The WAste Package DEGradation (WAPDEG) model (CRWMS M\&O 2000 [DIRS 151566]) is used to calculate drip-shield and waste-package degradation profiles with time in the GoldSim TSPA model configurations used for TSPA-SR, SSPA, and this Letter Report. Several input parameters to the WAPDEG model developed for TSPA-SR REV 00 ICN 01 (CRWMS M\&O 2000 [DIRS 151566]) were re-evaluated in SSPA Volume 1 (BSC 2001 [DIRS 154657], Section 7 , all). The re-evaluation led to the following changes to the TSPA-SR WAPDEG model and parameters used in the SSPA and the calculations in this Letter Report. These changes are described in detail in SSPA Volume 1 (BSC 2001 [DIRS 154657], Section 7, all) and are summarized here:

- All surface-breaking weld flaws and all weld flaws embedded in the outer $1 / 4$ of the closure weld thickness were considered capable of propagation in the radial direction in the WAPDEG Model developed for TSPA-SR REV 00 ICN 01 (CRWMS M\&O 2000 [DIRS 151566], Section 5.5, p. 39). In the SSPA and this analysis, the fraction of these weld flaws 
Analyses for Disposal of Commercial and DOE Waste Inventories at Yucca Mountain - Input to Final Environmental Impact Statement and Site Suitability Evaluation

capable of propagation in the radial direction is given by a \pm 3 standard deviation truncated lognormal distribution with a mean of 0.01 and bounded between 0.5 ( +3 standard deviations) and 0.0002 (-3 standard deviations) (BSC 2001 [DIRS 154657], Section 7.3.3.3.4, p. 7-41).

- The stress threshold for the initiation of stress-corrosion cracking was given by a uniform distribution between 20 and 30 percent of the Alloy 22 yield strength in the WAPDEG Model developed for TSPA-SR REV 00 ICN 01 (CRWMS M\&O 2000 [DIRS 151566], Section 4.1.9, p. 29). In the SSPA and this analysis, the stress threshold for the initiation of stress-corrosion cracking is given by a uniform distribution between 80 and 90 percent of the Alloy 22 yield strength (BSC 2001 [DIRS 154657], Section 7.3.3.3.3, p. 7-39).

- The uncertainty bounds of the residual-stress profile in the Alloy 22 waste package outer closure lid weld regions (induction annealed) were set to \pm 30 percent of the yield strength of Alloy 22 in the WAPDEG Model developed for TSPA-SR REV 00 ICN 01 (CRWMS M\&O 2000 [DIRS 151566], Section 6.5.1, p.79). In SSPA and this analysis, the uncertainty bounds of the residual stress profile in the Alloy 22 waste package outer closure lid weld regions were set to \pm 21.4 percent of the yield strength (BSC 2001 [DIRS 154657], Section 7.3.3.3.1, p. 7-74).

- The uncertainty bounds of the residual-stress profile in the Alloy 22 waste package inner closure lid weld regions (laser peened) were set to \pm 30 percent of the yield strength of Alloy 22 in the WAPDEG Model developed for TSPA-SR REV 00 ICN 01 (CRWMS M\&O 2000 [DIRS 151566], Section 6.5.1, p. 79). In SSPA and this analysis, the uncertainty bounds of the residual-stress profile in the Alloy 22 waste package inner closure lid weld regions are sampled from a cumulative distribution function (BSC 2001 [DIRS 154657], Section 7.3.3.3.2, p. 7-37 and Table.7.3.3-2, p. 7T-4).

- The variances of the general-corrosion-rate distributions for Alloy 22 and Titanium Grade 7 were considered to result from contributions of both uncertainty and variability in the WAPDEG Model developed for TSPA-SR REV 00 ICN 01 (CRWMS M\&O 2000 [DIRS 151566], Section 6.3.1, p. 55). In SSPA and this analysis, the total variance of the generalcorrosion-rate distributions is considered to be entirely due to uncertainty (BSC 2001 [DIRS 154657], Section 7.3.5.2, p. 7-54). Note that to ensure conservatism in the analysis, the temperature-dependent Alloy 22 general-corrosion model developed for the SSPA (BSC 2001 [DIRS 154657], Section 7.3.5.3.2, p. 7-56) was not used in the this analysis. The same Alloy 22 and Titanium Grade 7 general-corrosion-rate distributions used in the WAPDEG model developed for TSPA-SR REV 00 ICN 01 (CRWMS M\&O 2000 [DIRS 153246] Section 3.4.1, p. 3-80 to 3-87) and the SSPA (BSC 2001 [DIRS 154657], Section 7.3.5, p. 752 to 7.61) are also used in the calculations presented in this Letter Report. The calculated means of the general-corrosion-rate distribution used for the calculations in this Letter Report are $1.94 \times 10^{-4} \mathrm{~mm} / \mathrm{yr}$ for Titanium Grade 7 and $6.80 \times 10^{-5} \mathrm{~mm} / \mathrm{yr}$ for Alloy 22 . The data used to calculate the means are from complementary distribution functions presented in Analysis of Waste Package and Drip Shield Degradation (CRWMS M\&O 2000 [DIRS 151566], Section 4, p. 19 to 20. 
Analyses for Disposal of Commercial and DOE Waste Inventories at Yucca Mountain - Input to Final Environmental Impact Statement and Site Suitability Evaluation

\subsubsection{Early Waste-Package Failure}

The potential waste-package early-failure mechanisms were re-evaluated in the SSPA, particularly improper heat treatment of waste packages (BSC 2001 [DIRS 154657], Section 7.3.6, p.7-62). These results are incorporated in the calculations in this Letter Report. The results of the analysis show that the probability of having one waste package in the potential repository improperly heat-treated is about 20.2 percent, and the probability of having two waste packages affected is about 2.6 percent. The probability of having three waste packages with improper heat treatment is about 0.2 percent.

In evaluating the potential consequences of early failures by improper heat treatment for the SSPA and this analysis, early waste-package failure occurs upon initiation of corrosive processes and is due to failure of the outer and inner closure lids of the waste-package outer barrier and the failure of the closure lid of the stainless-steel structural waste-package inner shell. Details of the use of this model in performance-assessment analyses are discussed in SSPA Volume 2 (BSC 2001 [DIRS 154659], Section 3.2.5.4, p. 3-21). The following elements were employed in that evaluation:

- Those waste packages affected by early waste-package failure fail immediately by general corrosion as patches (BSC 2001 [DIRS 154659], Section 3.2.5.4, p. 3-21).

- The area on the waste package affected by improper heat treatment is equal to the area of closure-weld patches because improper heat treatment is most likely to occur during the induction annealing of the outer-closure-lid welds of the waste-package outer barrier.

- The materials of the entire affected area are lost upon failure of the waste packages because the affected area will be subject to stress-corrosion cracking and highly enhanced localized and general corrosion.

- The weld region of the inner closure lid of the outer barrier and the closure lid of the stainlesssteel structural inner shell fail at the same time when the outer closure-lid weld region fails.

The above assumptions are conservative because only the weld region of the outer lid of the outer barrier would be affected by potential improper heat treatment during the stress-mitigation heat treatment (i.e. induction annealing), and the inner lid of the outer barrier is not likely to be affected. In a more realistic scenario, the breached weld patches of the affected waste package would remain with the waste package until the weakened areas are affected by a major mechanical impact or corroded away by general corrosion.

\subsubsection{BDCFs for the 40 CFR Part 197 RMEI}

BDCFs are used to estimate the radiation dose incurred by a receptor when a unit activity concentration of a radionuclide reaches the accessible environment. The BDCFs for the RMEI were developed using the environmental and agricultural parameters characteristic of the Amargosa Valley region, and the dietary and lifestyle characteristics of the receptor consistent with those specified in 40 CFR Part 197.21 (66 FR 32074 [DIRS 155216], p. 32134). The lifestyle characteristics of the RMEI were representative of a rural residential population. The dietary characteristics of the RMEI were based on a food-consumption survey (DOE 1997 [DIRS 
Analyses for Disposal of Commercial and DOE Waste Inventories at Yucca Mountain - Input to Final Environmental Impact Statement and Site Suitability Evaluation

100332]) for the population of the town of Amargosa Valley. Consistent with the Final Rule at 40 CFR Part 197.21 ([DIRS 155216, p. 32134), the dietary characteristics of the RMEI were represented by the mean values of locally produced food for the Amargosa Valley residents. The dietary and lifestyle attributes of the RMEI are listed in Table 5-1. The dietary attributes of the RMEI shown in Table 5-1 were developed using the set of recently re-evaluated and updated values of consumption rates of locally produced food as found in Calculation: Consumption Rates of Locally Produced Food in Nye and Lincoln Counties (BSC 2001, [DIRS not yet available], all). This set of consumption rates is different from the set used in the TSPA-SR (CRWMS M\&O 2000 [DIRS 153246], Section 3.9, all) and the SSPA (BSC 2001 [DIRS 154657], Section 13, all) analyses. The changes include the update of the contingent average daily intake of food, the adjustments in the grouping of the food categories, and the adjustments in the selection of the individuals whose consumption rates were used to develop the receptors. If the same food-consumption data set, the same food grouping, and the individual selection criteria were used to construct the dietary characteristics of the AMCG under proposed NRC regulations (proposed 10 CFR PART 63.115(b), 64 FR 8640 [DIRS 107770], p 8645 to 8646), the consumption rates would be different from the values used in TSPA-SR. These modified attributes for the AMCG are also listed, for comparison, in Table 5-1.

Table 5-1 Comparison of the Average Values of the Dietary and Lifestyle Attributes for the Receptors

\begin{tabular}{|l|c|c|}
\hline \multirow{2}{*}{ Parameter } & \multicolumn{2}{c|}{ Mean Value of an Attribute for Annual Exposure } \\
\cline { 2 - 3 } & $\begin{array}{c}\text { Reasonably Maximally } \\
\text { Exposed Individual }\end{array}$ & $\begin{array}{c}\text { Average Member of the } \\
\text { Critical Group }\end{array}$ \\
\hline Leafy vegetables consumption rate, $\mathrm{kg} / \mathrm{yr}$ & 3.9 & 7.0 \\
\hline Other vegetables consumption rate, $\mathrm{kg} / \mathrm{yr}$ & 4.8 & 8.5 \\
\hline Fruit consumption rate, $\mathrm{kg} / \mathrm{yr}$ & 12.4 & 23.1 \\
\hline Grain consumption rate, $\mathrm{kg} / \mathrm{yr}$ & 0.3 & 0.6 \\
\hline Meat consumption rate, $\mathrm{kg} / \mathrm{yr}$ & 2.6 & 3.3 \\
\hline Poultry consumption rate, $\mathrm{kg} / \mathrm{yr}$ & 0.4 & 0.6 \\
\hline Milk consumption rate, $\mathrm{L} / \mathrm{yr}$ & 4.8 & 4.2 \\
\hline Eggs consumption rate, $\mathrm{kg} / \mathrm{yr}$ & 5.6 & 8.9 \\
\hline Fish consumption rate, $\mathrm{kg} / \mathrm{yr}$ & 0.3 & 0.5 \\
\hline Water consumption rate, $\mathrm{L} / \mathrm{yr}$ & 730 & 791.2 \\
\hline Inadvertent soil ingestion, $\mathrm{mg} / \mathrm{d}$ & 50 & 50 \\
\hline Inhalation exposure time, $\mathrm{hr}$ & 5073.5 & 6073.5 \\
\hline Soil exposure time, $\mathrm{hr}$ & 2387 & 3387 \\
\hline
\end{tabular}

The BDCFs for the two receptors, the RMEI, and the AMCG, characterized by the set of attributes listed in Table 5-1, are compared in Table 5-2. The comparison includes the BDCF values for the groundwater-release and the volcanic-eruption-exposure scenarios. Both the BDCFs for the RMEI and the BDCFs for the AMCG were developed using the same set of 
Analyses for Disposal of Commercial and DOE Waste Inventories at Yucca Mountain - Input to Final Environmental Impact Statement and Site Suitability Evaluation

environmental and agricultural parameters. Lifestyle characteristics of the AMCG were consistent with those of a farmer who works a considerable number of hours per year (full time or more) outdoors in the contaminated area and recreates a considerable number of hours per year outdoors in the contaminated area. The members of the critical group were assumed to consume domestically produced food and water and have gardens.

Table 5-2 Comparison of the BDCFs for the Receptors for the Groundwater Release and the VolcanicEruption Scenarios

\begin{tabular}{|c|c|c|c|c|c|c|}
\hline \multirow{2}{*}{ Radionuclide } & \multicolumn{3}{|c|}{ Groundwater release BDCFs, rem per $\mathrm{pCi} / \mathrm{L}$} & \multicolumn{3}{|c|}{$\begin{array}{c}\text { Volcanic-exposure-release BDCFs }{ }^{\text {a }} \\
\text { rem per } \mathrm{pCi} / \mathrm{m}^{2}\end{array}$} \\
\hline & RMEI & AMCG $^{\mathrm{D}}$ & $\begin{array}{l}\text { RMEI/AMCG } \\
\text { Ratio }\end{array}$ & RMEI & AMCG & $\begin{array}{l}\text { RMEI/AMCG } \\
\text { Ratio }\end{array}$ \\
\hline $\mathrm{C}-14$ & $2.9 \mathrm{E}-05$ & $5.8 \mathrm{E}-05$ & 0.50 & NA & NA & NA \\
\hline Se-79 & $1.2 \mathrm{E}-05$ & $1.5 \mathrm{E}-05$ & 0.77 & $3.8 \mathrm{E}-11$ & $5.5 \mathrm{E}-11$ & 0.69 \\
\hline Sr-90 & $2.0 \mathrm{E}-04$ & $2.6 \mathrm{E}-04$ & 0.75 & $4.2 \mathrm{E}-09$ & 7.1E-09 & 0.60 \\
\hline Tc-99 & $2.8 \mathrm{E}-06$ & $3.2 \mathrm{E}-06$ & 0.85 & NA & NA & NA \\
\hline $1-129$ & $2.5 \mathrm{E}-04$ & $3.0 E-04$ & 0.85 & $\overline{N A}$ & NA & NA \\
\hline Cs-137 & $3.4 \mathrm{E}-04$ & $4.8 \mathrm{E}-04$ & 0.71 & $1.2 \mathrm{E}-09$ & $1.8 \mathrm{E}-09$ & 0.68 \\
\hline $\mathrm{Pb}-210$ & $5.1 \mathrm{E}-03$ & $6.4 \mathrm{E}-03$ & 0.79 & $1.4 \mathrm{E}-08$ & $1.7 \mathrm{E}-08$ & 0.80 \\
\hline Ra-226 & $5.0 \mathrm{E}-03$ & $7.0 \mathrm{E}-03$ & 0.72 & $4.2 \mathrm{E}-09$ & $5.2 \mathrm{E}-09$ & 0.81 \\
\hline Ac-227 & $1.3 \mathrm{E}-02$ & $1.5 \mathrm{E}-02$ & 0.85 & $1.9 \mathrm{E}-06$ & 2.3E-06 & 0.84 \\
\hline Th-229 & $6.1 \mathrm{E}-03$ & $7.4 \mathrm{E}-03$ & 0.82 & $6.0 \mathrm{E}-07$ & 7.2E-07 & 0.84 \\
\hline Th-230 & $1.2 \mathrm{E}-03$ & $1.6 \mathrm{E}-03$ & 0.78 & $9.1 E-08$ & $1.1 \mathrm{E}-07$ & 0.84 \\
\hline $\mathrm{Pa}-231$ & $1.6 \mathrm{E}-02$ & $1.9 \mathrm{E}-02$ & 0.84 & $3.8 \mathrm{E}-07$ & $4.5 \mathrm{E}-07$ & 0.84 \\
\hline $\mathrm{U}-232$ & $1.8 \mathrm{E}-03$ & $2.3 \mathrm{E}-03$ & 0.80 & $1.9 \mathrm{E}-07$ & $2.3 E-07$ & 0.84 \\
\hline $\mathrm{U}-233$ & $2.8 \mathrm{E}-04$ & 3.4E-04 & 0.84 & $3.8 E-08$ & $4.6 \mathrm{E}-08$ & 0.84 \\
\hline $\mathrm{U}-234$ & $2.7 E-04$ & $3.3 \mathrm{E}-04$ & 0.84 & $3.8 \mathrm{E}-08$ & $4.5 E-08$ & 0.84 \\
\hline U-236 & $2.6 \mathrm{E}-04$ & $3.1 \mathrm{E}-04$ & 0.84 & $\mathrm{NA}$ & NA & NA \\
\hline $\mathrm{U}-238$ & $2.6 \mathrm{E}-04$ & $3.1 E-04$ & 0.83 & NA & NA & NA \\
\hline Np-237 & $4.5 \mathrm{E}-03$ & $5.4 \mathrm{E}-03$ & 0.84 & $1.9 \mathrm{E}-07$ & $2.3 \mathrm{E}-07$ & 0.83 \\
\hline Pu-238 & $2.9 \mathrm{E}-03$ & $3.4 \mathrm{E}-03$ & 0.85 & $1.1 \mathrm{E}-07$ & $1.4 \mathrm{E}-07$ & 0.84 \\
\hline Pu239 & $3.5 \mathrm{E}-03$ & $4.1 E-03$ & 0.85 & $1.3 \mathrm{E}-07$ & $1.5 \mathrm{E}-07$ & 0.84 \\
\hline Pu-240 & $3.5 \mathrm{E}-03$ & $4.1 \mathrm{E}-03$ & 0.85 & $1.3 \mathrm{E}-07$ & $1.5 \mathrm{E}-07$ & 0.84 \\
\hline Pu-242 & $3.2 \mathrm{E}-03$ & $3.8 \mathrm{E}-03$ & 0.85 & $1.2 \mathrm{E}-07$ & 1.4E-07 & 0.84 \\
\hline$A m-241$ & $3.5 \mathrm{E}-03$ & $4.8 \mathrm{E}-03$ & 0.72 & 1.3E-07 & $1.5 \mathrm{E}-07$ & 0.84 \\
\hline Am-243 & $4.0 \mathrm{E}-03$ & $4.8 \mathrm{E}-03$ & 0.83 & $1.3 \mathrm{E}-07$ & $1.5 \mathrm{E}-07$ & 0.84 \\
\hline $\begin{array}{l}\text { NOTES: } \\
\text { BDCFs for th } \\
\text { AMCG - No }\end{array}$ & 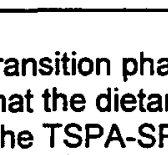 & ny & 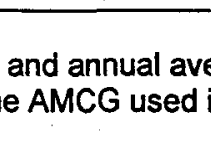 & & 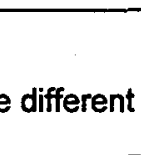 & hose of the \\
\hline
\end{tabular}

The comparison presented in Table 5-2 indicates that the BDCFs for the AMCG, calculated using the updated consumption rates of locally produced food and water, are up to a factor of 2 more conservative than the BDCFs for the RMEI for both exposure scenarios. In most cases the $\mathrm{BDCF}$ for the AMCG are greater than the BDCFs for the RMEI by only a factor of 1.2 to 1.3. Similar conclusions remain valid for the BDCFs used in the TSPA-SR because both the BDCFs for the AMCG developed using the preliminary and the modified food-consumption data sets are comparable. 
Analyses for Disposal of Commercial and DOE Waste Inventories at Yucca Mountain - Input to Final Environmental Impact Statement and Site Suitability Evaluation

The dietary and lifestyle characteristics of the AMCG are more conservative than those of the RMEI because the critical group represents the fraction of the Amargosa Valley population expected to experience higher-than-average potential exposures. Considering the ratios of the BDCFs for the RMEI and the AMCG presented in Table 5-2, a performance analysis using either of these receptors yields very similar results.

\subsubsection{Igneous-Activity Scenario}

The model and parameter changes from TSPA-SR to the model configuration used in the analysis for this Letter Report for the igneous-activity scenario are described in detail in SSPA Volume 1 (BSC 2001 [DIRS 154657], Sections 13 and 14, all) and are summarized here.

Several input parameters to the TSPA models used to calculate consequences of igneous disruption were changed subsequent to the TSPA-SR and have been included in this analysis (BSC 2001 [DIRS 154657], Section 14.3.3.7, all). Consistent with new information regarding the probability of an eruption at the location of the potential repository given an igneous intrusive event (BSC 2001 [DIRS 154657], Section 14.3, all), the conditional probability of an eruption at the potential repository was revised from 0.36 (CRWMS M\&O 2000 [DIRS 153246], Table 3.10-4, p. 198) to 0.77 (BSC 2001 [DIRS 154657], Section 14.3.3.1, p. 14-13). According to Characterize Framework for Igneous Activity at Yucca Mountain, Nevada. (CRWMS M\&O 2000 [DIRS 151551], Section 6.5.3.2, all, and Table 12a, p. 130), the approach for the calculation of the conditional number of eruptive centers occurring within the repository footprint was modified by: (1) using empirical distributions for the average spacing between eruptive centers rather than the expected values for these distributions; and (2) incorporating uncertainty in the effect of the repository opening on the conditional probability of the occurrence of an eruptive center within the potential repository footprint. This modified approach resulted in the new conditional probability of 0.77 for one eruptive center to occur involving the Primary Block of the HTOM repository footprint during or coincident with an igneous-activity event. This conditional probability has also been assumed for the LTOM analyses whose results are presented below in Section 6 .

Changes also were made in the probability distribution for an intrusive event, consistent with revisions in the potential repository footprint (i.e. changes related to the HTOM) since inputs were compiled for TSPA-SR. Revised distributions were provided for the number of waste packages affected by igneous-intrusion and volcanic-eruption scenarios, consistent with the revised event-probability information for the Primary Block of the HTOM. This adjusted event probability has also been assumed for the results of the LTOM analyses presented in Section 6. Changes have been made in the input data used to determine the wind speed during an eruption (BSC 2001 [DIRS 154657], Section 3.3.1.2.1, all). Additional changes in inputs to the TSPA-SR igneous-consequence model are listed in SSPA Volume 1 (BSC 2001 [DIRS 154657], Section 14.3.3.7, p. 14-24, and Tables 14.3.3.7-1 and 14.3.3.7-2, p. 14T-5 to 14T-6). Other model inputs and assumptions, including the assumption that wind direction is fixed toward the location of the receptor at all times, are the same as those used in the TSPA-SR (CRWMS M\&O 2000 [DIRS 153246] Section 3.10, all). 
Analyses for Disposal of Commercial and DOE Waste Inventories at Yucca Mountain - Input to Final Environmental Impact Statement and Site Suitability Evaluation

\subsubsection{Human-Intrusion Scenario}

The human-intrusion scenario for the calculations in this Letter Report was developed from that in the TSPA-SR (CRWMS M\&O 2000 [DIRS 153246], Section 4.4, all). The model changes implemented for the human-intrusion calculations in this Letter Report are described as follows.

Errata in the TSPA-SR human-intrusion model associated with "boosting" the inventory of certain radionuclides to account for first-generation daughter product transport through the 3-D SZ model (CRWMS M\&O 2000 [DIRS 148384], Section 6.3.4.1, p. 233) were corrected.

In the TSPA-SR human-intrusion model (CRWMS M\&O 2000 [DIRS 148384], Section 6.3.9.3, p. 513), for the purpose of determining thermohydrologic conditions, in-package chemistry, and in-drift chemistry, the failed waste package was placed in a specified dripping environment for a given infiltration condition. For the calculations in this Letter Report, the failed waste package for each realization of the human-intrusion scenario is randomly placed in one of several dripping environments depending on the infiltration condition.

Colloidal-facilitated transport of $\mathrm{Am}, \mathrm{Pu}, \mathrm{Th}$, and $\mathrm{Pa}$ in an exploratory borehole through the $\mathrm{UZ}$ has been included in the human-intrusion scenario in this Letter Report. Np-237, the daughter of irreversibly sorbed Am-241, is included as an irreversibly sorbed colloidal species. Colloidalfacilitated transport is implemented by adjusting the sorption coefficients of the aforementioned nuclides according to the relationship (CRWMS M\&O 2000 [DIRS 139440], p. 26):

where,

$$
K_{d}^{\text {adj }}=\frac{K_{d}^{\text {orig }}}{\left(1+K_{c}\right)}
$$

$$
\begin{aligned}
& K_{d}^{\text {orig }}=\text { sorption coefficient without colloidal-facilitated transport } \\
& K_{d}^{a d j}=\text { sorption coefficient with colloidal-facilitated transport } \\
& K_{c}=\text { colloid partition coefficient }
\end{aligned}
$$

The human-intrusion scenario included in this Letter Report was simulated for a 1,000,000-year duration (as opposed to the 100,000-year duration in the TSPA-SR). To be consistent with the SSPA 1,000,000-year calculations, two additional nuclides, ${ }^{228} \mathrm{Ra}$ and ${ }^{232} \mathrm{Th}$, are included in the inventory (BSC 2001 [DIRS 154657], Section 13.2.1.10, p. 13-9 to 13-10). The 30,000-year human-intrusion scenario is the same scenario analyzed in the SSPA (BSC 2001,Volume 1 [DIRS 154657], Appendix A, all). The information presented in this appendix addresses the issue of when a human intrusion could occur based upon the earliest time that current technology and practices could lead to a waste-package penetration without the driller noticing the wastepackage penetration. The time is effectively the time to general-corrosion failure of a waste package, approximately 30,000 years. The 100 -year human-intrusion scenario was developed based on NRC guidance provided at proposed 10 CFR Part 63.113d ([DIRS 107770], p. 8651 to 8652).

The assessment of the human-intrusion scenario did not combine the results of the humanintrusion scenario with the results of the disruptive igneous-activity scenario. However, 
Analyses for Disposal of Commercial and DOE Waste Inventories at Yucca Mountain - Input to Final Environmental Impact Statement and Site Suitability Evaluation

combined results can be approximated by adding the results of the human-intrusion calculations to the results of the igneous-activity scenario. Whether or not the intrusion occurred at 100 years or at 30,000 years, based on the results presented in sections 6.3 and 6.4 below, the highest mean annual dose to the RMEI that would result from a human intrusion would be more than an orderof-magnitude less, or one tenth, than the dose from a disruptive igneous event.

\subsection{SOURCE TERM}

The source term for the calculation of the annual dose histories associated with disposal of CSNF, DSNF, and HLW waste under all scenarios in this Letter Report includes the several waste forms that are contained in the waste packages. The descriptions of the types of waste, the packaging, the physical properties, and the dissolution models of the waste forms are presented in the TSPA-SR Rev 00 ICN 01(CRWMS M\& O 2000 [DIRS 153246], Sections 3.5.3 and 3.5.4, all).

\subsubsection{Radionuclide Inventories}

The calculations included in this Letter Report are based on radionuclide inventories which conform to the Nuclear Waste Policy Amendments Act of 1987 (NWPAA, Public Law 100-203 [DIRS 100016]) to include the total projected commercial and DOE waste. The materials comprising the 70,000-MTHM-case radionuclide inventory are described and tabulated in Inventory Abstraction (BSC 2001 [DIRS 154841], Table 36, p. 38). The tabulated per-package inventory used in these calculations is shown on Table 5-3. The cases analyzed, as directed by DOE, are described in Section 1. The radionuclide inventory used for Module 2 (i.e. GTCC and SPAR waste) is described and tabulated in DOE (1999 [DIRS 105155] Volume II, Appendix A, p. A-56 to A-61) and that per-package inventory is shown on Table 5-4. The details of obtaining the per-package inventory for GTCC and SPAR are described in Attachment III of this Letter Report.

Table 5-3 Per-Package Radionuclide Inventories for the CSNF and Co-Disposal Waste Packages

\begin{tabular}{|c|c|c|c|}
\hline \multirow[t]{2}{*}{ Isotope } & \multirow{2}{*}{$\begin{array}{l}\text { CSNF Waste Packages } \\
\text { (grams/waste package) }\end{array}$} & \multicolumn{2}{|c|}{$\begin{array}{l}\text { Co-Disposal Waste Packages } \\
\text { (grams/waste package) }\end{array}$} \\
\hline & & From DSNF & From HLW Glass \\
\hline${ }^{227} \mathrm{AC}$ & $3.09 \mathrm{E}-06$ & $1.13 \mathrm{E}-04$ & $4.67 \mathrm{E}-04$ \\
\hline${ }^{241} \mathrm{Am}$ & $1.09 E+4$ & $1.17 E+02$ & $6.57 E+01$ \\
\hline${ }^{243} \mathrm{Am}$ & $1.29 E+03$ & $1.49 \mathrm{E}+00$ & 3.99E-01 \\
\hline${ }^{14} \mathrm{C}$ & $1.37 E+00$ & $4.69 \mathrm{E}-02$ & $6.43 \mathrm{E}-03$ \\
\hline${ }^{137} \mathrm{Cs}$ & $5.34 E+03$ & $1.12 \mathrm{E}+02$ & $4.51 E+02$ \\
\hline 129 & $1.80 \mathrm{E}+03$ & $2.51 E+01$ & $4.80 \mathrm{E}+01$ \\
\hline${ }^{237} \mathrm{~Np}$ & $4.74 E+03$ & $4.79 E+01$ & $7.23 E+01$ \\
\hline 231 $\mathrm{Pa}$ & 9.87E-03 & $3.25 \mathrm{E}-01$ & 7.96E-01 \\
\hline${ }^{210} \mathrm{~Pb}$ & $0.00 E+00$ & 1.40E-08 & $1.14 \mathrm{E}-07$ \\
\hline${ }^{238} \mathrm{Pu}$ & $1.51 E+03$ & $6.33 \mathrm{E}+00$ & $9.33 \mathrm{E}+01$ \\
\hline${ }^{239} \mathrm{Pu}$ & $4.38 \mathrm{E}+04$ & $2.30 \mathrm{E}+03$ & $3.89 E+03$ \\
\hline${ }^{240} \mathrm{Pu}$ & $2.09 E+04$ & $4.89 \mathrm{E}+02$ & $3.81 E+02$ \\
\hline${ }^{242} \mathrm{Pu}$ & $5.41 E+03$ & $1.11 \mathrm{E}+01$ & $7.77 \mathrm{E}+00$ \\
\hline${ }^{226} \mathrm{Ra}$ & $0.00 \mathrm{E}+00$ & 1.87E-06 & 1.67E-05 \\
\hline${ }^{228} \mathrm{Ra}$ & $0.00 E+00$ & $6.98 E-06$ & $3.19 E-06$ \\
\hline${ }^{90} \mathrm{Sr}$ & $2.24 E+03$ & $5.54 \mathrm{E}+01$ & $2.88 E+02$ \\
\hline
\end{tabular}


Analyses for Disposal of Commercial and DOE Waste Inventories at Yucca Mountain - Input to Final Environmental Impact Statement and Site Suitability Evaluation

Table 5-3 Per-Package Radionuclide Inventories for the CSNF and Co-Disposal Waste Packages (cont.)

\begin{tabular}{|c|c|c|c|}
\hline \multirow[t]{2}{*}{ Isotope } & \multirow{2}{*}{$\begin{array}{l}\text { CSNF Waste Packages } \\
\text { (grams/waste package) }\end{array}$} & \multicolumn{2}{|c|}{$\begin{array}{l}\text { Co-Disposal Waste Packages } \\
\text { (grams/waste package) }\end{array}$} \\
\hline & & From DSNF & From HLW Glass \\
\hline${ }^{99} \mathrm{Tc}$ & $7.68 \mathrm{E}+03$ & $1.15 E+02$ & $7.29 \mathrm{E}+02$ \\
\hline $2291 n$ & $0.00 E+00$ & $2.66 \mathrm{E}-02$ & $4.08 \mathrm{E}-03$ \\
\hline $230 \mathrm{~m}$ & $1.84 \mathrm{E}-01$ & 1.06E-02 & 7.82E-03 \\
\hline${ }^{232} \mathrm{Th}$ & $0.00 E+00$ & $1.49 E+04$ & $7.31 E+03$ \\
\hline${ }^{232} \mathrm{U}$ & $1.01 \mathrm{E}-02$ & $1.47 E-01$ & $8.23 E-04$ \\
\hline${ }^{233} \mathrm{U}$ & $7.00 E-02$ & $2.14 \mathrm{E}+02$ & $1.11 E+01$ \\
\hline${ }^{234} \mathrm{U}$ & $1.83 E+03$ & $5.72 E+01$ & $4.72 E+01$ \\
\hline${ }^{235} \mathrm{U}$ & $6.28 E+04$ & $8.31 E+03$ & $1.70 \mathrm{E}+03$ \\
\hline${ }^{236} \mathrm{U}$ & $3.92 E+04$ & $8.53 E+02$ & $3.98 \mathrm{E}+01$ \\
\hline${ }^{238} \mathrm{U}$ & $7.92 E+06$ & $5.09 E+05$ & $2.61 \mathrm{E}+05$ \\
\hline
\end{tabular}

DTN: SN0003T0810599.010 [DIRS 151021]

Table 5-4 Per-Package Radionuclide Inventories for the GTCC and SPAR Waste

\begin{tabular}{|l|l|}
\hline \multicolumn{1}{|c|}{ Isotope } & \multicolumn{1}{c|}{$\begin{array}{c}\text { GTCC and SPAR } \\
\text { (grams/Waste Package) }\end{array}$} \\
\hline${ }^{27} \mathrm{Ac}$ & $0.00 \mathrm{E}+00$ \\
\hline${ }^{241} \mathrm{Am}$ & $4.00 \mathrm{E}+01$ \\
\hline${ }^{243} \mathrm{Am}$ & $1.51 \mathrm{E}-03$ \\
\hline${ }^{14} \mathrm{C}$ & $2.89 \mathrm{E}+01$ \\
\hline${ }^{137} \mathrm{Cs}$ & $7.71 \mathrm{E}+02$ \\
\hline${ }^{129} \mathrm{I}$ & $7.05 \mathrm{E}-04$ \\
\hline${ }^{237} \mathrm{~Np}$ & $0.00 \mathrm{E}+00$ \\
\hline${ }^{231} \mathrm{~Pa}$ & $0.00 \mathrm{E}+00$ \\
\hline${ }^{210} \mathrm{~Pb}$ & $0.00 \mathrm{E}+00$ \\
\hline${ }^{238} \mathrm{Pu}$ & $1.56 \mathrm{E}+00$ \\
\hline${ }^{239} \mathrm{Pu}$ & $2.86 \mathrm{E}+03$ \\
\hline${ }^{240} \mathrm{Pu}$ & $1.23 \mathrm{E}-02$ \\
\hline${ }^{241} \mathrm{Pu}$ & $2.07 \mathrm{E}-02$ \\
\hline${ }^{242} \mathrm{Pu}$ & $6.14 \mathrm{E}-03$ \\
\hline${ }^{226} \mathrm{Ra}$ & $5.04 \mathrm{E}-02$ \\
\hline${ }^{90} \mathrm{Sr}$ & $8.20 \mathrm{E}-01$ \\
\hline${ }^{99} \mathrm{Tc}$ & $5.68 \mathrm{E}+02$ \\
\hline${ }^{229} \mathrm{Th}$ & $0.00 \mathrm{E}+00$ \\
\hline${ }^{230} \mathrm{Th}$ & $0.00 \mathrm{E}+00$ \\
\hline${ }^{232} \mathrm{U}$ & $2.87 \mathrm{E}-06$ \\
\hline${ }^{233} \mathrm{U}$ & $4.19 \mathrm{E}-03$ \\
\hline${ }^{234} \mathrm{U}$ & $0.00 \mathrm{E}+00$ \\
\hline${ }^{235} \mathrm{U}$ & $0.00 \mathrm{E}+00$ \\
\hline${ }^{236} \mathrm{U}$ & $0.00 \mathrm{E}+00$ \\
\hline${ }^{238} \mathrm{U}$ & $5.63 \mathrm{E}+05$ \\
\hline${ }^{5}$ & \\
\hline
\end{tabular}

See Attachment IIl of this Letter Report for

development of the data included in this table. 
Analyses for Disposal of Commercial and DOE Waste Inventories at Yucca Mountain - Input to Final Environmental Impact Statement and Site Suitability Evaluation

\subsubsection{Waste Packaging}

The waste packages simulated in this Letter Report include CSNF packages and DSNF-HLW codisposal packages as described in the Update to the EIS Engineering File for the Waste Package in Support of the Final EIS (CRWMS M\&O 2000 [DIRS 150558], Section 4.3, all).

\subsubsection{Waste Form Physical Properties}

The physical properties of the various waste forms for the CSNF, DSNF, and HLW to be placed in the proposed Yucca Mountain repository are described in detail in the TSPA-SR (CRWMS 2000 [DIRS 153246], Section 3.5). The waste-form modeling consists of the in-package chemistry model, dissolution models for each waste form type (CSNF, DSNF, HLW), concentration limits for each radionuclide (representing the effect of the formation of secondary phases), and the formation and sorption of colloids (BSC 2001 [DIRS 154657], Sections 3 and 4, all).

\subsubsection{Cladding Failure}

The model and parameter changes from TSPA-SR to the model configuration used in this analysis for the cladding degradation are described in detail in SSPA Volume 1 (BSC 2001 [DIRS 154657], Section 9.3.3, p. 9-18 to 9-23) and are summarized here. The SSPA model was a modification of the cladding model developed in the TSPA-SR (CRWMS M\&O 2000 [DIRS 148384], Section 3.5.4, p. 3-111 to 3-118).

The cladding-degradation component of the SSPA model used in the calculation presented in this Letter Report consists of six components. These components are represented by mathematical distributions covering the expected range of values of the parameters used in the calculation. The degradation components incorporated in the cladding model are:

1. The number of rods initially perforated in a CSNF waste package from reactor operation, shipping, or during dry storage,

2. The fraction of cladding perforated because of creep rupture and stress-corrosion cracking,

3. Cladding failure from localized corrosion,

4. Failure from mechanical damage, namely due to seismic events (Rock-overburden failures have been added for sensitivity calculations since the TSPA-SR model was developed.),

5. The CSNF degradation rate (intrinsic dissolution), and

6. The unzipping of the cladding, which represents the exposure of the surface area of the CSNF matrix inside the cladding and its availability for degradation.

\section{RESULTS}

The GoldSim simulations in support of this Letter Report estimate the dose to the RMEI for both the 70,000-MTHM-case inventory and expanded-inventory cases (119,000 MTHM plus GTCC and SPAR waste), and for igneous-activity and human-intrusion scenarios. The downgradient 
RMEI location, has been specified by DOE as the farthest southern point at the boundary of the controlled area and the accessible environment, as defined in 40 CFR Part 197.12 (66 FR 32074 [DIRS 155216], p. 32133). This is the location where radiological results, i.e. RMEI dose and groundwater protection, are calculated. According to 40 CFR Part 197.21 and Part 197.31 (66 FR 32074 [DIRS 155216], p. 32134 to 32135), compliance should be evaluated at the point above the highest concentration of radionuclides in the simulated plume of contamination where the plume crosses the southernmost boundary of the controlled area, at a Latitude of $36^{\circ} 40^{\prime} 13.6661^{\prime \prime}$ North, and enters the accessible environment approximately $18 \mathrm{~km}$ downgradient from the repository. This location corresponds to where the RMEI, who lives in an average farming community, would consume and use groundwater withdrawn from wells. In accordance with 40 CFR Part 197.35 ([DIRS 155216], p. 32135), the annual dose was calculated for the period of geologic stability which is $1,000,000$ years. These calculations indicate that GoldSim simulations extending from repository closure to $1,000,000$ years after repository closure include both the 10,000 and 1,000,000 year performance periods specified in 40 CFR Part 197.20 and 197.35 (66 FR 32074 [DIRS 155216], p 32134 and 32135). The calculations included in this Letter Report also show the peak dose for all scenarios. The location is also the location where a representative volume of groundwater would be withdrawn and whose radiation cannot exceed the limits of 40 CFR Part 197.30 Table 1 ([DIRS 155216] p. 32134). This Letter Report also evaluates groundwater protection at that location.

The data from the multiple realizations can be summarized by showing time versus annual dose (i.e. annual dose histories) for the $5^{\text {th }}$ and $95^{\text {th }}$ percentile of the output, along with the mean and median of the output. In the same manner as described for TSPA-SR (CRWMS M\&O 2000 [DIRS 153246], Section 2.2.4.6, p. 2-39 to 2-40), these statistical measures are calculated for all 300 realizations of the probabilistic simulations at each time step of the dose histories. The plot of the mean represents the average of all 300 data points at each time step. For each point on the plot of the median dose, 50 per cent of the data have a value greater than the plotted point and 50 per cent have a value less that the plotted point. Likewise, for the $95^{\text {th }}$ and $5^{\text {th }}$ percentiles, the plotted data points are such that 5 percent of data are greater (or less) than the plotted point and 95 per cent of the data points are less (or greater) than the plotted points, for each point, or time step, plotted. The statistical measures are superimposed, in contrasting colors, on plots that show all 300 realizations, also known as "horsetail plots".

The data files containing all the graphical and tabular results for the calculations presented in this report have been submitted to the Records Processing Center along with a list of the files and instructions on retrieving these data. (Saulnier, G. 2001. "Delivery of Input and Output Files used in the Analyses for Disposal of Commercial and DOE Waste Inventories at Yucca Mountain - Input to Final Environmental Impact Statement and Site Suitability Evaluation." MOL.20010917.0192 [155948], all).

\subsection{WASTE PACKAGE FAILURE}

Figure 6-1 shows the waste-package failure curves for the 70,000-MTHM case for the 1,000,000-year performance period for the HTOM. The figure indicates that the first wastepackage failures occur at less than 10,000 years after repository closure. These early wastepackage failures are due to improper heat treatment, manufacturing defects, and materials failures (Section 5.4.2). The figure shows that only from 1 to 3 waste packages incur early 
Analyses for Disposal of Commercial and DOE Waste Inventories at Yucca Mountain - Input to Final Environmental Impact Statement and Site Suitability Evaluation

failure. Because waste-package failure is the first step in releasing radionuclides for groundwater flow and transport, the figure demonstrates that, for the 70,000-inventory case, the early dose to receptors before 10,000 years postclosure is orders of magnitude less than the peak dose that occurs a few hundred-thousand years after repository closure as shown in results presented in Section 6.2 below.

Figure 6-2 shows cladding perforated during the post-closure period and includes the averaged impact of seismic events. The cladding failure results presented in Figure 6-2 are essentially the same as developed in the SSPA (BSC 2001 [DIRS 154659], p.9-19 to 9-23).

\subsection{ANNUAL DOSE HISTORIES FOR THE 1,000,000- YEAR PERFORMANCE PERIOD}

This Letter Report presents graphical representations of annual dose histories for the inventories and scenarios described in Section 1. The performance period for the calculations in this Letter Report was generally $1,000,000$ years after repository closure except in the case of the igneousactivity scenarios. The annual dose histories for the igneous-activity scenarios were calculated for 100,000 years postclosure. In addition to the following graphical presentations, Table 6-1 shows the values of a) the peak mean annual dose (and the time of the peak dose) for all scenarios that occurs in the 10,000-year, 100,000-year, and 1,000,000-year postclosure performance periods, in accordance with 40 CFR Part 197.20, 197.25, and 1978.35 (66 FR 32074 [DIRS 155216], p. 32134 to 32135 ), and b) the peak $95^{\text {th }}$ percentile dose for the same performance periods and scenarios.

\subsubsection{Annual Dose Due to the 70,000-MTHM Inventory}

\subsubsection{Annual Dose Calculated for the High-Temperature Operating Mode}

Figure 6-3 shows the mean annual dose results of the 300 probabilistic simulations for the HTOM (approximately $56 \mathrm{MTHM}$ /acre) for the 70,000-MTHM inventory at the RMEI location $(\sim 18 \mathrm{~km}$ downgradient from the repository) for $1,000,000$ years after repository closure. Figure 6-3 also shows the results of the TSPA-SR nominal-case results for comparison (CRWMS M\&O 2000 [DIRS 153246], Figure 4.1-19a, p. F4-19). Figure 6-4 displays the relative contribution of selected radionuclides that contribute most to the total mean annual dose due to all radionuclides. Figure 6-5 displays the results of the 300 probabilistic simulations of the 70,000-MTHM inventory, HTOM, at the RMEI location $(\sim 18 \mathrm{~km})$ downgradient from the repository for $1,000,000$ years after repository closure. This figure displays the results for each realization and the $5^{\text {th }}$ and $95^{\text {th }}$ percentiles, and the mean and median of these simulations. 
Analyses for Disposal of Commercial and DOE Waste Inventories at Yucca Mountain - Input to Final Environmental Impact Statement and Site Suitability Evaluation

Table 6-1 Peak Dose and Year of Peak Dose by Scenario for Various Performance Periods: (a) Peak Mean Annual Dose; (b) Peak $95^{\text {th }}$ Annual Dose

a) Peak Mean Annual Dose

\begin{tabular}{|c|c|c|c|c|c|c|c|}
\hline \multicolumn{8}{|c|}{ hean Annual Dose (mrem/yr) } \\
\hline \multirow{2}{*}{ Case } & \multirow{2}{*}{ Model File } & \multicolumn{2}{|c|}{ 10,000 yr Peak } & \multicolumn{2}{|c|}{ T00,000 yr peak } & \multicolumn{2}{|c|}{$1,000,000$ yr Peak } \\
\hline & & Value & Year & Value & Year & Value & Year \\
\hline 70,000 МТНIM, НTOM & SE01_006nm6 & T.7E-05 & 4875 & T.2E-01 & 99,500 & 152.5 & 476,000 \\
\hline 70,000 MTHM, LTOM & SE01_007nm6 & 1.1E-05 & 3437.5 & 8.5E-02 & 99,500 & 122.2 & 476,000 \\
\hline Module 1, HTOM & SE01_010nm6 & 2.7E-05 & 4937.5 & 1.6E-01 & 100,000 & 237.9 & 476,000 \\
\hline Module 2, HTOM & SE01_011nm6 & 6.8E-04 & 3687.5 & 6.8E-04 & 3687.5 & 3.3E-01 & 208,000 \\
\hline Igneous Activity, HTOM & SE01_001im5 & 1.0E-01 & 312.5 & 1.0E-01 & 312.5 & & \\
\hline Igneous Activity, LTOM & SE01_002im5 & 1.0E-01 & 312.5 & $1.0 \mathrm{E}-01$ & 312.5 & & \\
\hline Igneous Activity, HTOM (Intrusive Only) & SE01_001im5 & 4.3E-04 & 10000 & 2.1E-02 & 48,000 & & \\
\hline Igneous Activity, LTOM (Intrusive Only) & SE01_002im5 & 5.0E-04 & 10000 & 2.8E-02 & 48,000 & & \\
\hline Igneous Activity, HTOM (Eruptive Only) & SE01_001im5 & 1.0E-01 & 312.5 & 1.0E-01 & 312.5 & & \\
\hline Igneous Activity, LTOM (Eruptive Only) & SE01_002im5 & 1.0E-01 & 312.5 & 1.0E-01 & 312.5 & & \\
\hline Human Intrusion 30k-yr Event, HTOM & SE01_001hm6 & & & 1.7E-03 & 30562.5 & 2.3E-03 & 108,000 \\
\hline Human Intrusion 100-yr Event, HTOM & SE01_002hm6 & 4.8E-03 & 875 & 4.8E-03 & 875 & 4.8E-03 & 875 \\
\hline
\end{tabular}

b) Peak 95th Percentile Dose

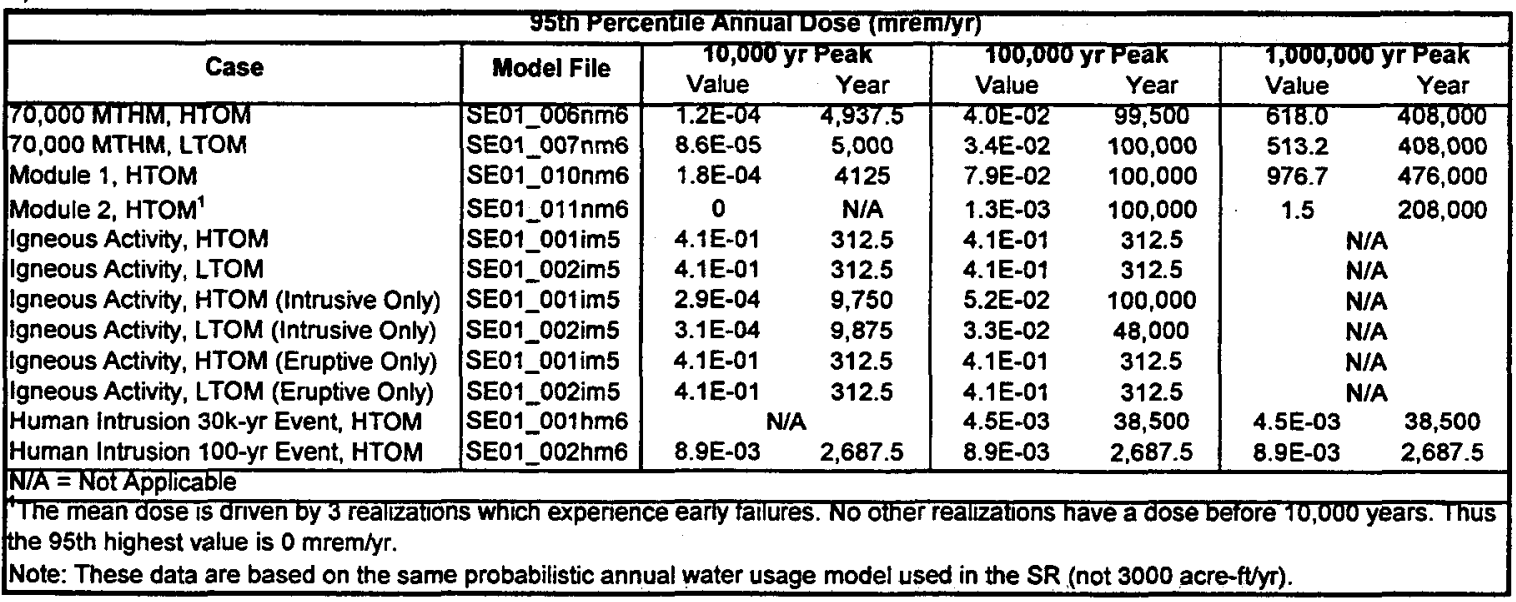

\subsubsection{Annual Dose Calculated for the Low-Temperature Operating Mode}

Figure 6-3 displays representations of the mean annual dose results of the 300 probabilistic simulations for the LTOM (approximately $45 \mathrm{MTHM}$ /acre) for the 70,000 MTHM inventory at the RMEI location ( $18 \mathrm{~km}$ downgradient from the repository) for 1,000,000 years after repository closure. Because Figure 6-3 shows little difference between the annual dose histories calculated for the HTOM and the LTOM, the remaining scenarios, other than the igneousactivity scenario, were only simulated for the HTOM.

Figure 6-6 displays the results of the 300 probabilistic simulations of the $70,000-\mathrm{MTHM}$ case, LTOM, at the RMEI location $(\sim 18 \mathrm{~km})$ downgradient from the repository for $1,000,000$ years after repository closure. This figure displays the results for each realization and the $5^{\text {th }}$ and $95^{\text {th }}$ percentiles, and the mean and median of these simulations. 
Analyses for Disposal of Commercial and DOE Waste Inventories at Yucca Mountain - Input to Final Environmental Impact Statement and Site Suitability Evaluation

\subsubsection{Annual Dose Due for the Module 1 Expanded Inventory, High-Temperature Operating Mode}

Figures 6-7 displays the annual dose histories for the 300 probabilistic simulations of the expanded-inventory Module 1, HTOM, case (119,000 MTHM) at the RMEI location ( 18 km) downgradient from the repository for $1,000,000$ years after repository closure. This figure displays the results for each realization and the $5^{\text {th }}$ and $95^{\text {th }}$ percentiles, and the mean and median of these simulations.

\subsubsection{Annual Dose Due to the Module 2 Expanded Inventory, High-Temperature Operating Mode}

A GoldSim simulation was also performed for a case that included only the GTCC and SPAR components of the Module 2 inventory. The case did not include the other components of the Module 2 inventory i.e., the 119,000 MTHM of the Module 1 inventory. The GoldSim simulation for only the Module 2 GTCC and SPAR inventory, HTOM, was performed as a separate probabilistic case at the RMEI location $(\sim 18 \mathrm{~km})$ downgradient from the repository. Figure 6-8 displays the annual dose histories for the 300 probabilistic simulations of the radioactive components of GTCC and SPAR components of the Module 2 inventory. The effects of non-radioactive components of this waste are not included in the analysis. This figure displays the results for each realization and the $5^{\text {th }}$ and $95^{\text {th }}$ percentiles, and the mean and median of these simulations.

6.2.4 Comparison of Mean Annual Dose Due to the 70,000 MTHM Inventory, the Module 1 Expanded Inventory, and the Module 2 Expanded Inventory, High-Temperature Operating Mode

Figure 6-9 is a comparison plot of the mean annual dose versus time for the 70,000 MTHM inventory, HTOM, and the expanded-inventory cases for the Module 1 and Module 2 inventories, HTOM, at the RMEI location downgradient from a repository. These results show that during the first 10,000 years, the mean annual dose due to the GTCC and SPAR components of the Module 2 inventory is greater than that calculated for the 70,000 MTHM and Module 1 inventories, but is essentially zero. After 10,000 years, the dose due to the GTCC and SPAR components of the Module 2 inventory is about two orders of magnitude less than that calculated for the 70,000 MTHM and Module 1 inventories. These results indicate that the addition of the GTCC and SPAR waste to the Module 1 inventory would not materially increase the mean annual dose. As a result of this comparison, separate probabilistic simulations were deemed to be unnecessary for Module 2, either as separate simulations of the GTCC and SPAR components of the Module 2 inventory or combined with the Module 1 inventory, i.e. as the complete Module 2 inventory.

\subsection{ANNUAL DOSE FOR THE IGNEOUS-ACTIVITY SCENARIOS}

The performance of a Yucca Mountain repository was evaluated for a combined igneous-activity scenario that included both an igneous event and a volcanic eruption. Probability-weighted simulations of the combined igneous-activity scenario were performed for the HTOM and LTOM for the 70,000 MTHM inventory. However, probability-weighted annual dose histories were not calculated for the igneous-activity scenario for the expanded-inventory cases. 
Analyses for Disposal of Commercial and DOE Waste Inventories at Yucca Mountain - Input to Final Environmental Impact Statement and Site Suitability Evaluation

\subsubsection{Annual Dose Due to the High-Temperature Operating Mode}

Figure 6-10a displays representations of the probability-weighted annual dose histories for 500 of the 5,000 probabilistic simulations for the igneous-activity scenario, HTOM (approximately $56 \mathrm{MTHM} /$ acre) for the 70,000 MTHM inventory at the RMEI location ( $18 \mathrm{~km}$ downgradient from the repository) for 100,000 years after repository closure. Figure $6-10 \mathrm{a}$ displays the $5^{\text {th }}$ and $95^{\text {th }}$ percentiles, and the mean and median of all 5,000 probability-weighted igneous-activity simulations. The results presented in Figure 6-10a represent the combined effect of both the igneous-intrusion and eruptive events.

Figure 6-10b displays the probability-weighted mean annual dose versus time for the igneousactivity scenario for the 70,000-MTHM inventory for the HTOM at the RMEI location downgradient from a repository. The figure also displays the mean results for both the eruptive and intrusive events. Figure 6-10c displays the probability-weighted mean annual dose versus time for the igneous-activity scenarios, which represent the sum of the igneous and eruptive events, for the TSPA-SR nominal case (CRWMS M\&O 2000 [DIRS 153246], Figure 4.1-19a, p. F4-19), and the 70,000-MTHM inventory for the HTOM and LTOM at the RMEI location downgradient from a repository.

\subsubsection{Annual Dose Due to the Low-Temperature Operating Mode}

Figure 6-11a displays representations of the probability-weighted annual dose histories for 500 of the 5,000 probabilistic simulations for the igneous-activity scenario, LTOM (approximately $45 \mathrm{MTHM} / \mathrm{acre})$ for the 70,000 MTHM inventory at the RMEI location ( $18 \mathrm{~km}$ downgradient from the repository) for 100,000 years after repository closure. Figure $6-11$ a displays the $5^{\text {th }}$ and $95^{\text {th }}$ percentiles, and the mean and median of all 5,000 probability-weighted igneous-activity simulations. The results presented in Figure 6-11a represent the combined effect of both the igneous-intrusion and eruptive events.

Figure 6-11b displays the probability-weighted mean annual dose versus time for the igneousactivity scenario for the 70,000-MTHM inventory for the LTOM at the RMEI location downgradient from a repository. The figure also displays the mean results for both the eruptive and intrusive events.

\subsection{MEAN ANNUAL DOSE CALCULATED FOR THE HUMAN-INTRUSION SCENARIO}

The performance of a Yucca Mountain repository was evaluated for the human-intrusion scenario for intrusions at two different postclosure times as described in Section 5.2.7 above. The human-intrusion scenario was simulated for the HTOM for the 70,000 MTHM inventory. Annual dose histories were not calculated for the human-intrusion scenario for the expandedinventory scenarios.

\subsubsection{Annual Dose Due to Human Intrusion at 30,000 years after Repository Closure, High-Temperature Operating Mode}

Figure 6-12 displays representations of the annual dose results of the 300 probabilistic simulations for the human-intrusion scenario, 30,000 years after repository closure, with a 
Analyses for Disposal of Commercial and DOE Waste Inventories at Yucca Mountain - Input to Final Environmental Impact Statement and Site Suitability Evaluation

70,000-MTHM inventory for the HTOM at the RMEI location downgradient from the repository. Figure 6-12 displays the results for each simulation and the $5^{\text {th }}$ and $95^{\text {th }}$ percentiles, and the mean and median of these simulations.

\subsubsection{Annual Dose Due to Human Intrusion at 100 years after Repository Closure, High- Temperature Operating Mode}

Figure 6-13 displays representations of the annual dose histories of the 300 probabilistic simulations for the human-intrusion scenario, 100 years after repository closure, with a 70,000MTHM inventory for the HTOM at the RMEI location downgradient from the repository. The figure displays the results for each simulation and the $5^{\text {th }}, 95^{\text {th }}$, mean and median of these simulations.

\subsection{COMPARATIVE RESULTS}

Figure 6-14 displays four mean annual dose histories; the 70,000-MTHM inventory, HTOM, calculated for this Letter Report; the TSPA-SR (CRWMS M\&O 2000 [DIRS 153246], Figure 4.1-19a, p. F4-19), and the SSPA, both LTOM, and HTOM (BSC 2001 [DIRS 154659], Figure 4.1-1, p. 4F-1).

Figure 6-15 displays the mean annual dose histories for all the calculation scenarios described in this Letter Report and the TSPA-SR case (CRWMS M\&O 2000 [DIRS 153246], Figure 4.1-19a, p. F4-19).

Figure 6-16 displays a comparison of the annual dose versus time for the 70,000 MTHM inventory, (HTOM and LTOM), the igneous-activity scenario (HTOM and LTOM), and the TSPA-SR case for the 100,000-year performance period (CRWMS M\&O 2000 [DIRS 153246], Figure 4.1-5, p. F4-5).

\subsection{GROUNDWATER PROTECTION}

An analysis of groundwater protection was conducted in accordance with the EPA Final Rule 40 CFR Parts 197.30 and 197.31 (66 FR 32074 [DIRS 15216], p. 32134 to 32135). The rule is based on meeting three groundwater radionuclide-concentration levels. The first is the maximum concentration of ${ }^{226} \mathrm{Ra}$ and ${ }^{228} \mathrm{Ra}$ in a representative volume of 3,000 acre-ft of groundwater in a release from the potential repository. The second groundwater-concentration level is for the gross alpha activity (excluding radon and uranium) in the representative volume of groundwater. Both of these calculations apply to releases from both natural sources and the potential repository at the same location as the RMEI. The third groundwater-protection calculation is the dose to the whole body or any organ of a human receptor for beta- and photonemitting radionuclides released from the potential repository. For this calculation, the receptor would consume two (2) liters per day from the representative volume of groundwater. This groundwater is that which would be withdrawn annually from an aquifer containing less than $10,000 \mathrm{mg} / \mathrm{L}$ of total dissolved solids, and centered on the highest concentration in the plume of contamination at the same location as the RMEI. The results of the calculations for this Letter Report produced data consistent with the EPA Final Rule and are presented graphically and in tabular form. 
Analyses for Disposal of Commercial and DOE Waste Inventories at Yucca Mountain - Input to Final Environmental Impact Statement and Site Suitability Evaluation

Table 6-4 Maximum Dose to Critical Organs in 10,000 years for ${ }^{99} \mathrm{Tc},{ }^{14} \mathrm{C}$, ${ }^{129} \mathrm{I}$, and Total of All Betaand Photon-Emitting Radionuclides

\begin{tabular}{|c|c|c|c|c|c|}
\hline \multicolumn{5}{|c|}{ Maximum Dose to Critical organs In 10,000 years (mrem/yr) } & \multirow[b]{2}{*}{ Total } \\
\hline Case & TModelfile & TC-99 & $C=14$ & T-129 & \\
\hline 70,000MTHAM, НTOM & SE01_006nm6 & $7.2 \mathrm{E}-05$ & 2.4E-07 & 9.1E-06 & $2.2 \mathrm{E}-05$ \\
\hline 70,000 MTHM, LTOM & SEOT_007nm6 & 7.0E-06 & $7.8 \mathrm{E}-07$ & 7.5E-06 & 7.5E-05 \\
\hline Human Intrusion 30k-yr Event, HTOM & SE01_001 $1 \mathrm{~nm} 6$ & N/A & N/A & $-N / A$ & N/A \\
\hline Human Intrusion 100-yr Event, HTOM & SE01_002hm6 & $2.4 E-03$ & 8.4E-05 & $2.5 E-03$ & $5.0 E-03$ \\
\hline N/A = Not Applicable & & & & & \\
\hline
\end{tabular}

\section{REFERENCES}

\subsection{DOCUMENTS CITED}

100103 Bodvarsson, G.S.; Bandurraga, T.M.; and Wu, Y.S., eds. 1997. The Site-Scale Unsaturated Zone Model of Yucca Mountain, Nevada, for the Viability Assessment. LBNL-40376. Berkeley, California: Lawrence Berkeley National Laboratory. ACC: MOL.19971014.0232

100449 Golder Associates 1998. Repository Integration Program RIP Integrated Probabilistic Simulator for Environmental Systems Theory Manual and User's Guide. Redmond, Washington: Golder Associates. TIC: 238560

100474 Nitao, J.J. 1998. Reference Manual for the NUFT Flow and Transport Code, Version 2.0. UCRL-MA-130651. Livermore, California: Lawrence Livermore National Laboratory. TIC: 238072

100550 DOE (U.S. Department of Energy) 1998. Total System Performance Assessment. Volume 3 of Viability Assessment of a Repository at Yucca Mountain. DOE/RW-0508. Washington, D.C.: U.S. Department of Energy, Office of Civilian Radioactive Waste Management. ACC: MOL.19981007.0030

105155 DOE (U.S. Department of Energy) 1999. Draft Environmental Impact Statement for a Geologic Repository for the Disposal of Spent Nuclear Fuel and High-Level Radioactive Waste at Yucca Mountain, Nye County, Nevada. DOE/EIS-0250D. Summary, Volumes I and II. Washington, D.C.: U.S. Department of Energy, Office of Civilian Radioactive Waste Management. ACC: MOL.19990816.0240

107889 Zyvoloski, G.A.; Robinson, B.A.; Dash, Z.V.; and Trease, L.L. 1999. Users Manual for the FEHM Application. STN: 10031-UM-2.00-00. Los Alamos, New Mexico: Los Alamos National Laboratory. ACC: MOL.19990810.0038 
Analyses for Disposal of Commercial and DOE Waste Inventories at Yucca Mountain - Input to Final Environmental Impact Statement and Site Suitability Evaluation

139440 CRWMS M\&O 2000. Input and Results of the Base Case Saturated Zone Flow and Transport Model for TSPA. ANL-NBS-HS-000030 REV 00. Las Vegas, Nevada: CRWMS M\&O. ACC: MOL.20000526.0330

139610 CRWMS M\&O 2000. Multiscale Thermohydrologic Model. ANL-EBS-MD-000049 REV 00. Las Vegas, Nevada: CRWMS M\&O. ACC: MOL.20000609.0267

142877 LL000113904242.089. TSPA-SR Lower Calculations. Submittal date: 01/28/2000.

142884 LL000114004242.090. TSPA-SR Mean Calculations. Submittal date: 01/28/2000.

142886 LL000114104242.091. TSPA-SR Primary Calculations. Submittal date: 01/28/2000.

143556 Golder Associates 2000. User's Guide, GoldSim, Graphical Simulation Environment. Version 6.02. Draft \#3. Redmond, Washington: Golder Associates. TIC: 247324

148384 CRWMS M\&O 2000. Total System Performance Assessment (TSPA) Model for Site Recommendation. MDL-WIS-PA-000002 REV 00. Las Vegas, Nevada: CRWMS M\&O. ACC: MOL.20001226.0003

149540 DOE (U.S. Department of Energy) 2000. Quality Assurance Requirements and Description. DOE/RW-0333P, Rev. 10. Washington, D.C.: U.S. Department of Energy, Office of Civilian Radioactive Waste Management. ACC: MOL.20000427.0422

150558 CRWMS M\&O 2000. Update to the EIS Engineering File for the Waste Package in Support of the Final EIS. TDR-EBS-MD-000010 REV 00 ICN 01. Las Vegas, Nevada: CRWMS M\&O. ACC: MOL.20000317.0446

150941 CRWMS M\&O 2000. FEIS Update to Engineering File - Subsurface Repository. TDR-EBS-MD-000007 REV 00 ICN 01. Las Vegas, Nevada: CRWMS M\&O. ACC: MOL.20000612.0058

151021 SN0003T0810599.010. Revised Average Radionuclide Activities for Commercial Spent Nuclear Fuel (CSNF) and Co-Disposal Waste Packages for Total System Performance Assessment-Site Recommendation (TSPA-SR) and Final Environmental Impact Statement (TSPA-FEIS). Submittal date: 03/15/2000.

151395 Golder Associates 1999. Software Code: RIP. 5.19.01. 30055 V5.19.01.

151551 CRWMS M\&O 2000. Characterize Framework for Igneous Activity at Yucca Mountain, Nevada. ANL-MGR-GS-000001 REV 00 ICN 01. Las Vegas, Nevada: CRWMS M\&O. ACC: MOL.20001221.0001.

151566 CRWMS M\&O 2000. WAPDEG Analysis of Waste Package and Drip Shield Degradation. ANL-EBS-PA-000001 REV 00 ICN 01. Las Vegas, Nevada: CRWMS M\&O. ACC: MOL.20001208.0063. 
Analyses for Disposal of Commercial and DOE Waste Inventories at Yucca Mountain - Input to Final Environmental Impact Statement and Site Suitability Evaluation

152059 BSC (Bechtel SAIC Company) 2001. Performance Assessment of U. S. Department of Energy Spent Fuels in Support of Site Recommendation. CAL-WIS-PA-000002 REV 00. Las Vegas, Nevada: Bechtel SAIC Company. ACC: MOL.20010627.0026.

153246 CRWMS M\&O 2000. Total System Performance Assessment for the Site Recommendation. TDR-WIS-PA-000001 REV 00 ICN 01. Las Vegas, Nevada: CRWMS M\&O. ACC: MOL.20001220.0045

153849 DOE (U.S. Department of Energy) 2001. Yucca Mountain Science and Engineering Report. DOE/RW-0539. [Washington, D.C.]: U.S. Department of Energy, Office of Civilian Radioactive Waste Management. ACC: MOL.20010524.0272.

154554 BSC (Bechtel SAIC Company) 2001. Lower-Temperature Subsurface Layout and Ventilation Concepts. ANL-WER-MD-000002 REV 00. Las Vegas, Nevada: Bechtel SAIC Company. ACC: MOL.20010718.0225

154594 CRWMS M\&O 2001. Abstraction of NFE Drift Thermodynamic Environment and Percolation Flux. ANL-EBS-HS-000003 REV 00 ICN 02. Las Vegas, Nevada: CRWMS M\&O. ACC: MOL.20010221.0160

154657 BSC (Bechtel SAIC Company) 2001. FY01 Supplemental Science and Performance Analyses, Volume 1: Scientific Bases and Analyses. TDR-MGR-MD-000007 REV 00. Las Vegas, Nevada: Bechtel SAIC Company. ACC: MOL.20010712.0062

154659 BSC (Bechtel SAIC Company) 2001. FY01 Supplemental Science and Performance Analyses, Volume 2: Performance Analyses. TDR-MGR-PA-000001 REV 00. Las Vegas, Nevada: Bechtel SAIC Company. ACC: MOL.20010724.0110

154841 BSC (Bechtel SAIC Company) 2001. Inventory Abstraction. ANL-WIS-MD-000006 REV 00 ICN 02. Las Vegas, Nevada: Bechtel SAIC Company. ACC: MOL.20010416.0088

155182 BSC (Bechtel SAIC Company) 2001. Software Code: GoldSim. V7.17.200. 103447.17.200-00. URN-0901

155393 CRWMS M\&O 2000. EIS Performance-Assessment Analyses for Disposal of Commercial and DOE Waste Inventories at Yucca Mountain. CAL-CRW-PA-000002 REV 00. Las Vegas, Nevada: CRWMS M\&O. ACC: MOL.20000801.0002

155906 BSC 2001. Technical Work Plan For Additional Performance Analyses to Support Site Suitability Evaluation and Final Environmental Impact Statement With Respect To 40 CFR 197. DI Number: TWP-MGR-MD-000016 Rev 00

155948 Saulnier, G. 2001. "Delivery of Input and Output Files used in the Analyses for Disposal of Commercial and DOE Waste Inventories at Yucca Mountain - Input to Final Environmental Impact Statement and Site Suitability Evaluation." Memorandum from 
Analyses for Disposal of Commercial and DOE Waste Inventories at Yucca Mountain - Input to Final Environmental Impact Statement and Site Suitability Evaluation

G. Saulnier (Duke Austin) to Jerry McNeish (Duke Las Vegas), September 17, 2001, EIS 9/17/01, PROJ.09/01.015, with enclosures. ACC: MOL.20010917.0192.

In Process BSC 2001, Calculation: Consumption Rates of Locally Produced Food in Nye and Lincoln Counties CAL-MGR-MD-000005, REVISION 00

\subsection{CODES, STANDARDS, AND REGULATIONS}

100016 Nuclear Waste Policy Amendments Act of 1987. Public Law No. 100-203. 101 Stat. 1330. Readily available.

10168064 FR 8640. Disposal of High-Level Radioactive Wastes in a Proposed Geologic Repository at Yucca Mountain, Nevada. Proposed rule 10 CFR Part 63. Readily available

105989 Energy Policy Act of 1992. 42 U.S.C. 13201 et seq. Readily available.

107770 NRC (U.S. Nuclear Regulatory Commission) 1998. "Proposed Rule: 10 CFR Part 63---'Disposal of High-Level Radioactive Wastes in a Proposed Geologic Repository at Yucca Mountain, Nevada'." SECY-98-225. [Washington, D.C.: U.S. Nuclear Regulatory Commission]. Accessed October 30, 1999. TIC: 240520.

155216 66 FR 32074. 40 CFR Part 197, Public Health and Environmental Radiation Protection Standards for Yucca Mountain, NV; Final Rule. Readily available.

\subsection{PROCEDURES}

AP-SI.1Q, Rev. 3, ICN 01, ECN 01. Software Management. Washington, D.C.: U.S. Department of Energy, Office of Civilian Radioactive Waste Management. ACC:MOL.20010705.0239.

\section{ATTACHMENTS}

Attachments

I

II

III
Title

Acronyms and Abbreviations

Extracting Repository Release Nodes

GTCC and SPAR Inventory 
Analyses for Disposal of Commercial and DOE Waste Inventories at Yucca Mountain - Input to Final Environmental Impact Statement and Site Suitability Evaluation

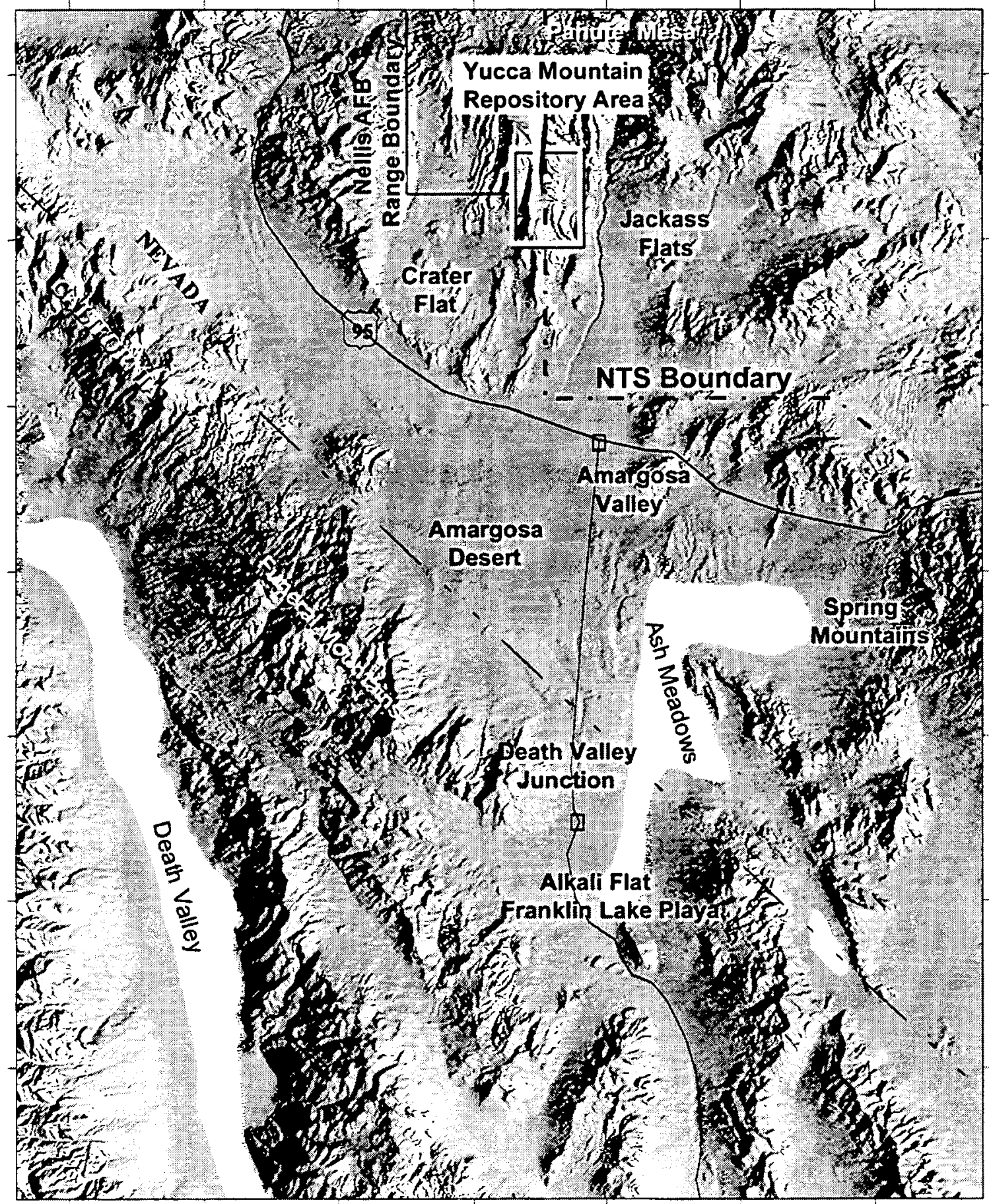

$1 \quad 10 \quad 20$ Kilometers

Figure 5-1 Location of a Potential Yucca Mountain Repository 
Analyses for Disposal of Commercial and DOE Waste Inventories at Yucca Mountain - Input to Final Environmental Impact Statement and Site Suitability Evaluation

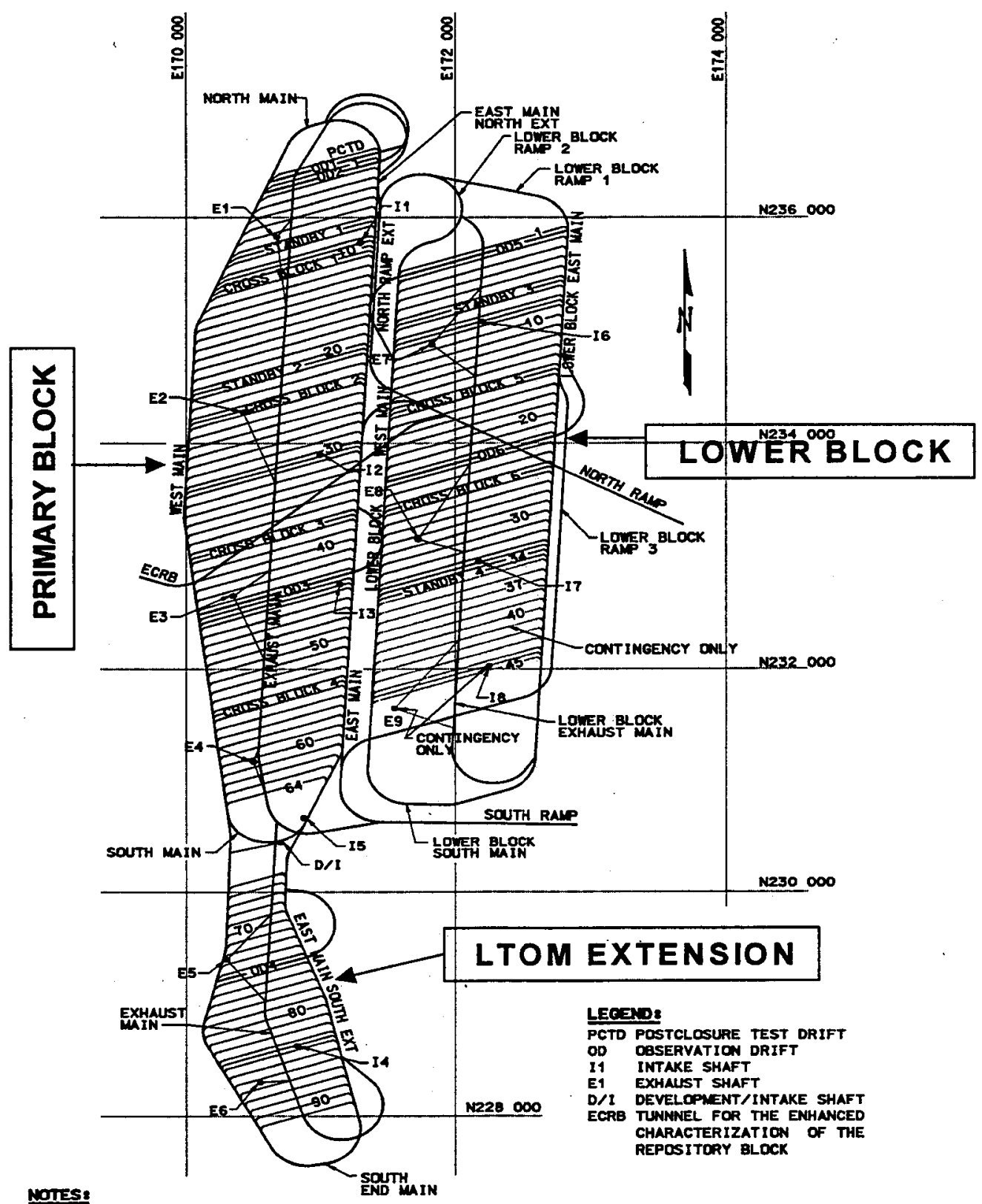

1. DIEENSIDNS, COORDIMUTES. AND ELEVATIONS ARE

2. NORTHING AND EASTING YALUES ARE MEVADA STATE

PLAN CAD FILE: fob-2001-1t-119kmtu
SCALE: NONE

\section{Feb_2001_lt_119kmtu.PPT}

Figure 5-2 Approximate configuration of a potential Yucca Mountain Repository.

Note:Disposal for the 70,000 MTHM case under the HTOM would utilize the Primary Block. Disposal for the Expanded-inventory Case, approximately 119,000 MTHM, would utilize the Primay Block and the Lower Block. (Source BSC 2001 [DIRS 154554], Section 6.1.2.1, Figure 3, p. 43 of 126) 
Analyses for Disposal of Commercial and DOE Waste Inventories at Yucca Mountain - Input to Final Environmental Impact Statement and Site Suitability Evaluation

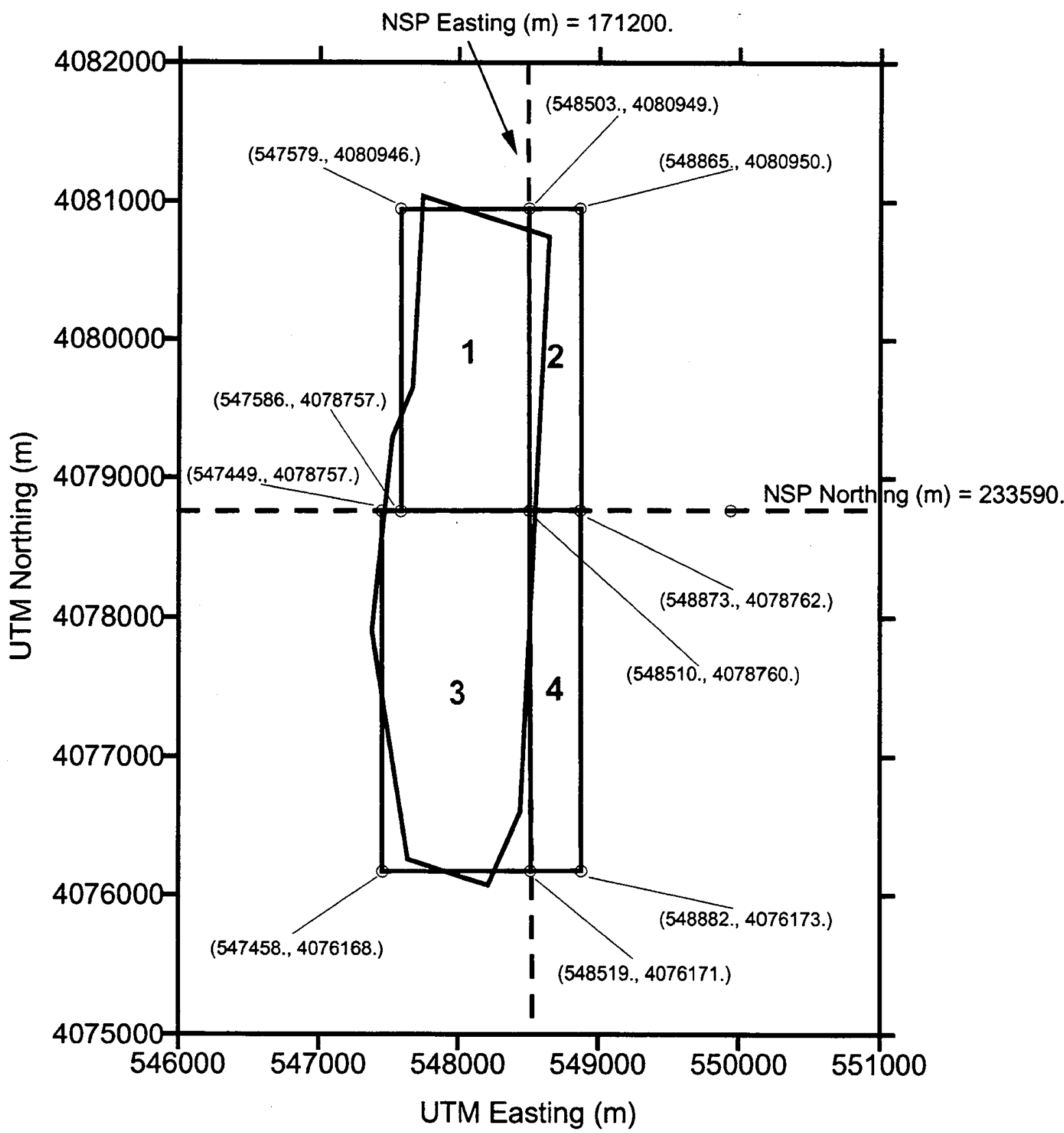

NOTE: Source Regions are outlined with the solid black rectangles and numbered from 1 to 4 . The coordinates of the vertices of the source region rectangles are given in UTM coordinates $(\mathrm{m})$. The outline of the repository is shown by the blue lines. The dashed red lines indicate the quadrants from which radionuclide arrivals from the UZ model are applied to the SZ source regions. Coordinates of the dashed red lines are given in Nevada State Plan (NSP) coordinates (m). Source TSPA-SR (CRWMS M\&O 2000 [DIRS 153246], Figure 3.8-14, p. F3-117)

Figure 5-3 The Four Saturated-Zone Capture Regions in Relation to the Primary Repository Block for the 70,000-MTHM-Inventory Case 
Analyses for Disposal of Commercial and DOE Waste Inventories at Yucca Mountain - Input to Final Environmental Impact Statement and Site Suitability Evaluation

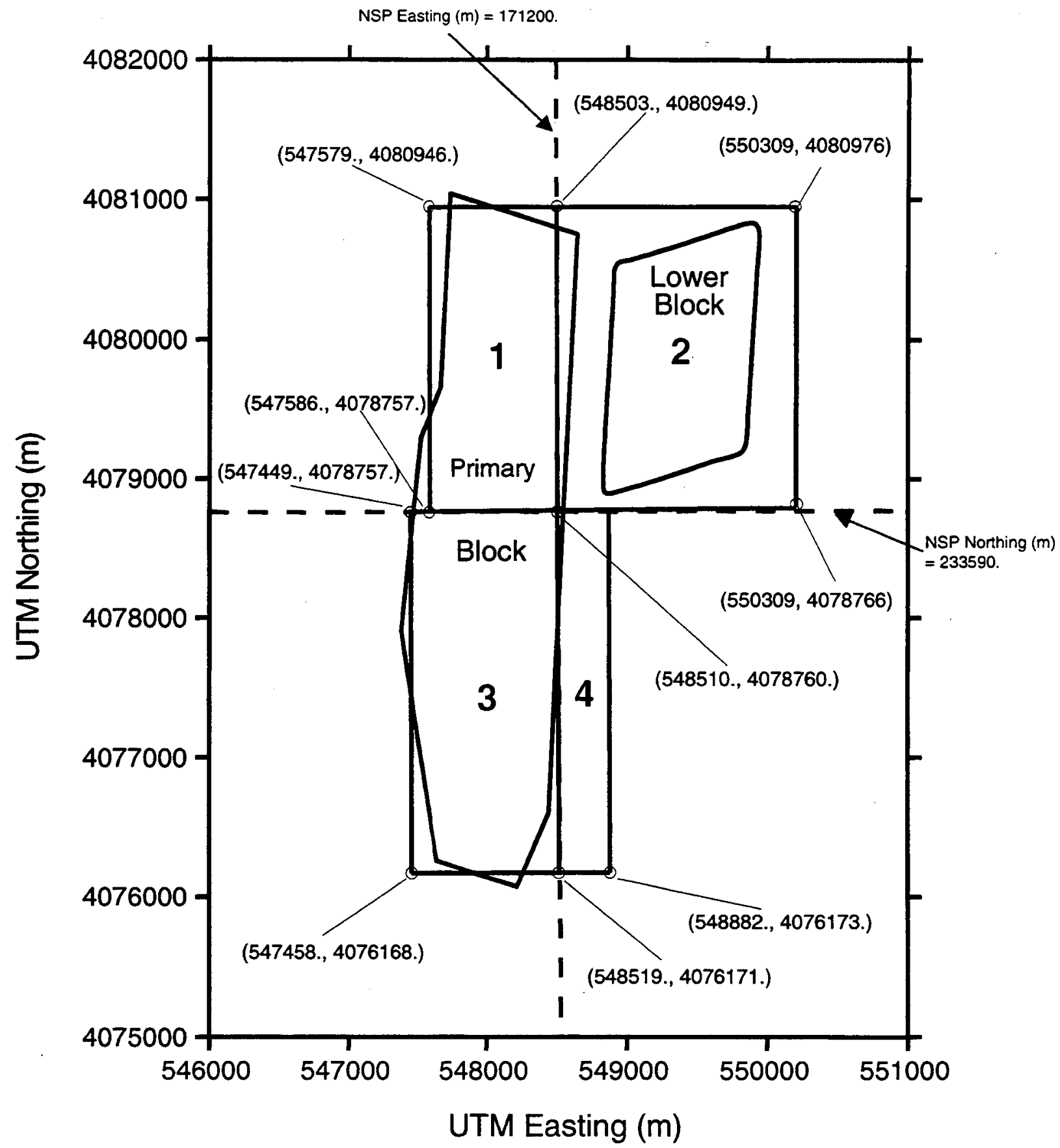

NOTE: Source Regions are outlined with the solid black rectangles and numbered from 1 to 4 .

The coordinates of the vertices of the source region rectangles are given in UTM coordinates $(\mathrm{m})$. The outline of the repository is shown by the blue lines. The dashed red lines indicate the quadrants from which radionuclide arrivals from the $\mathrm{UZ}$ model are applied to the $\mathrm{SZ}$ source regions. Coordinates of the dashed red lines are given in Nevada State Plan (NSP) coordinates (m). Source CRWMS M\&O 2000 ([DIRS 155393], Figure 5-5, p. 25)

Figure 5-4 The Four Saturated-Zone Capture Regions in Relation to the Primary and Lower Repository Blocks for the Expanded-Inventory Case 
Analyses for Disposal of Commercial and DOE Waste Inventories at Yucca Mountain - Input to Final Environmental Impact Statement and Site Suitability Evaluation

\section{Location of Elements from Site Scale Model within Lower Block}

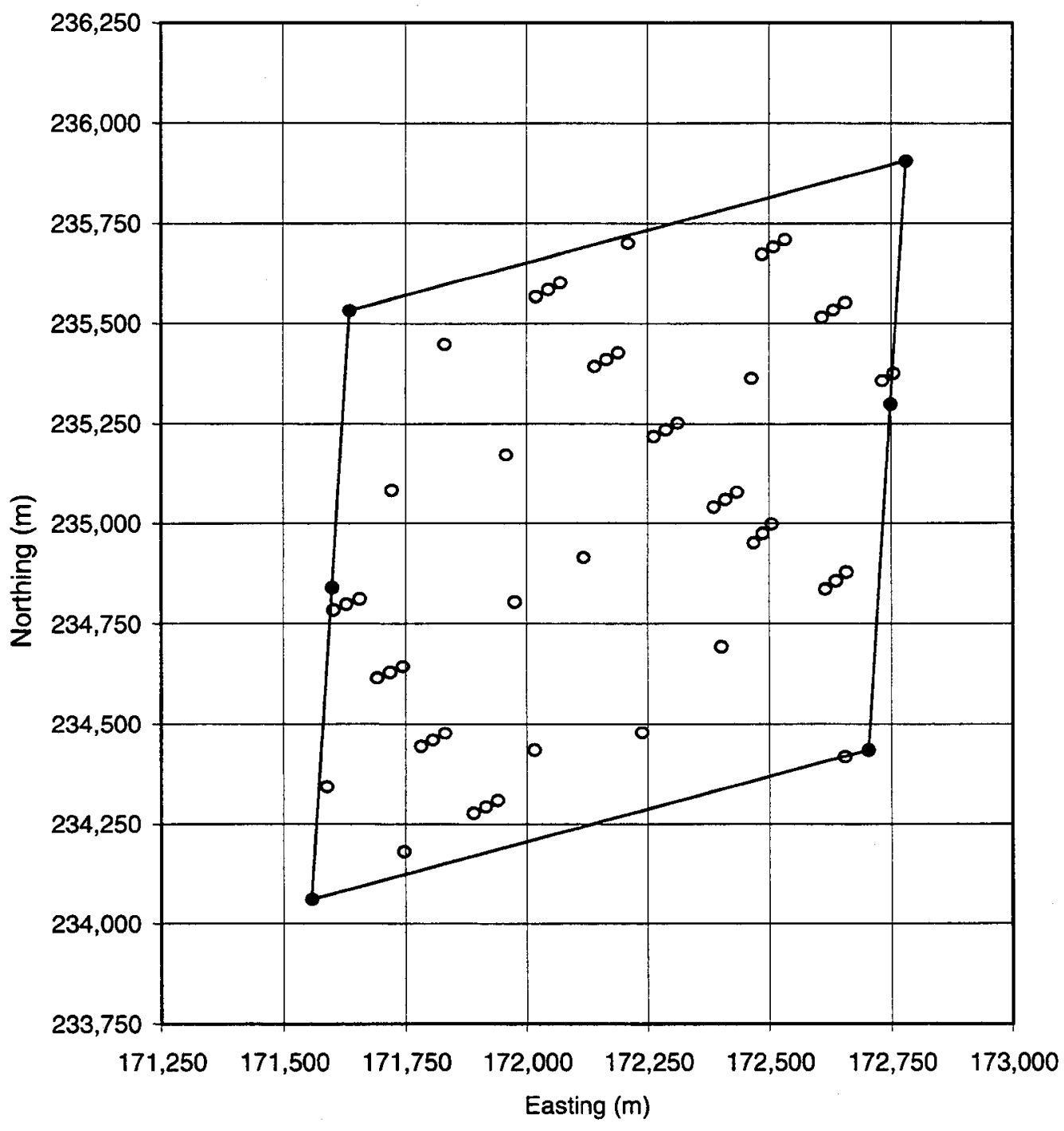

Figure 5-5 Outline of the Lower Block Showing the Locations of the 51 Particle-Tracking Nodes. Source CRWMS M\&O 2000 ([DIRS 155393], Figure 5-6, p. 26) 
Analyses for Disposal of Commercial and DOE Waste Inventories at Yucca Mountain - Input to Final Environmental Impact Statement and Site Suitability Evaluation



NOTE: The yellow dashed line represents the southernmost boundary between the controlled area and accessible environment ( $36^{\circ} 40^{\prime} 13.6661^{\prime \prime}$ North latitude as per EPA 40 CFR Part 197 (66 FR 32074 [DIRS 155216])). The red dashed line represents the 20-km fence used in TSPA-SR to evaluate compliance with proposed EPA and NRC regulations. The purple crosses represent $S Z$ model grid cells at the intersection of the new southernmost boundary with the $20-\mathrm{km}$ fence used in TSPA-SR evaluations. The red crosses are well locations, and the blue lines represent Highway 95 and Highway 373. Source BSC 2001 [DIRS 154657] Figure 12.5.3-1, p. 12 F-37.

Figure 5-6 Southernmost Boundary of the Controlled Area and the Accessible Environment 
Analyses for Disposal of Commercial and DOE Waste Inventories at Yucca Mountain - Input to Final Environmental Impact Statement and Site Suitability Evaluation

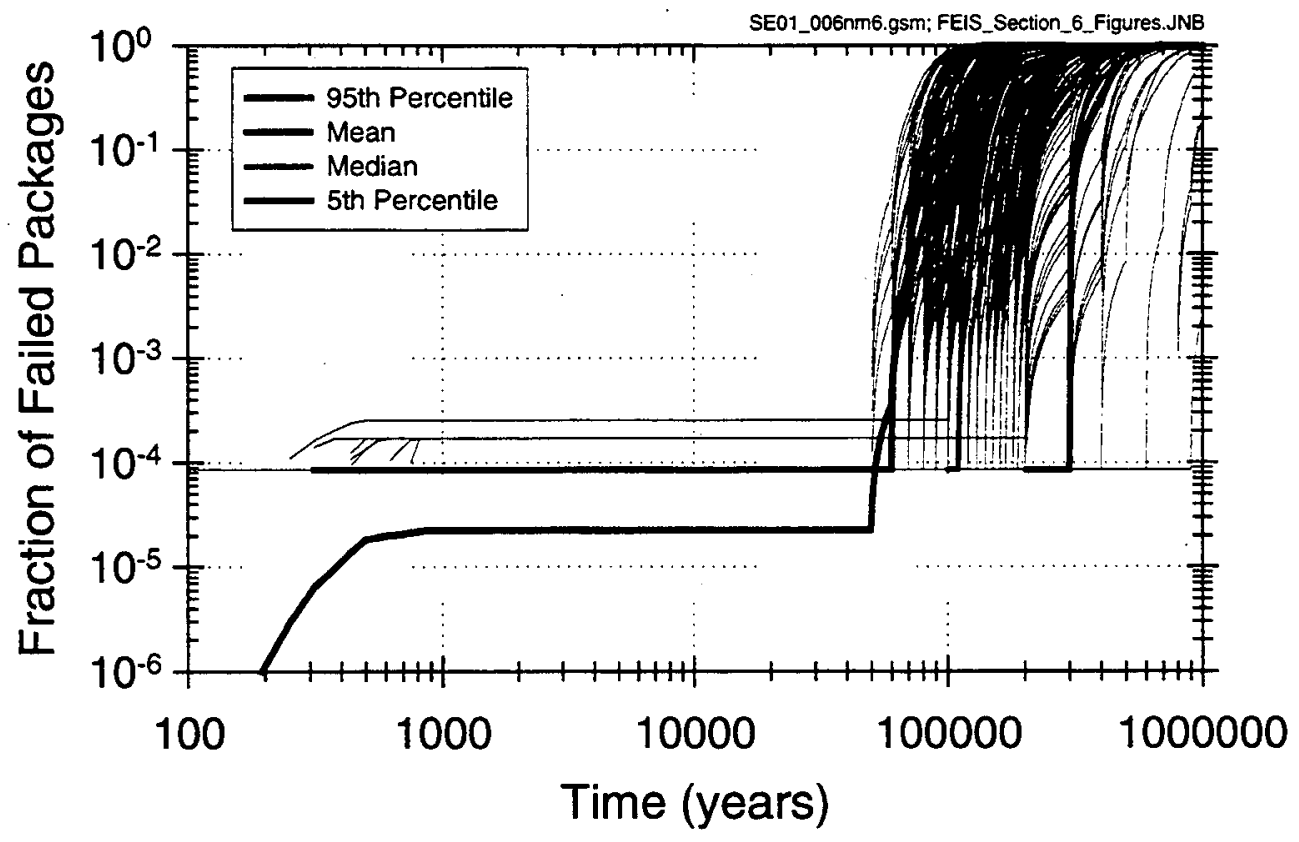

Figure 6-1 Waste-Package Failure Curves for the 70,000-MTHM Inventory and the $5^{\text {th }}$ and $95^{\text {th }}$ Percentiles, and the Mean and Median of these Simulations 


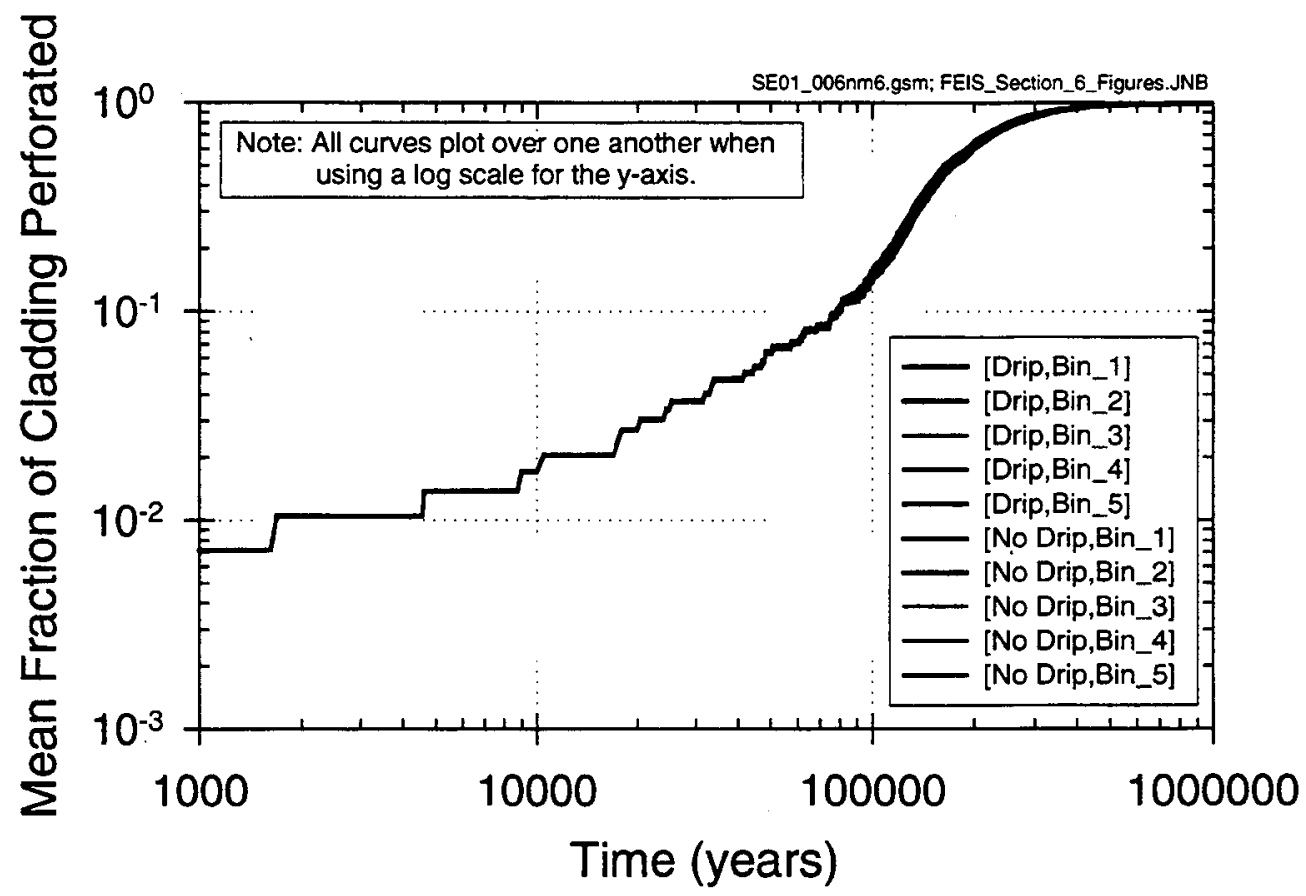

Figure 6-2 Cladding-Failure Profile for the 70,000-MTHM-Inventory Case 


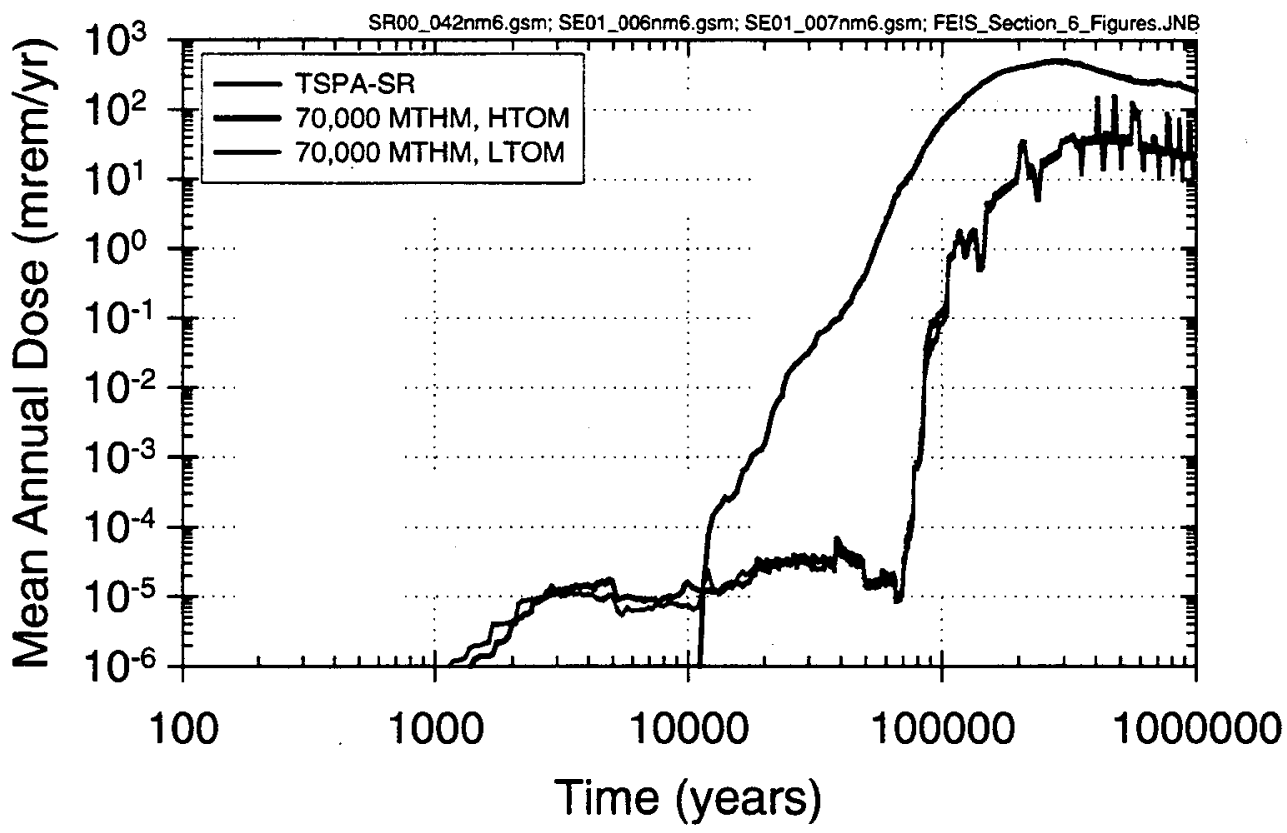

Figure 6-3 Comparison Plot of the Mean Annual Dose versus Time for the TSPA-SR Case, the High Temperature Operating Mode and the LTOM for the 70,000-MTHM Inventory at the RMEI Location Downgradient from a Yucca Mountain Repository 


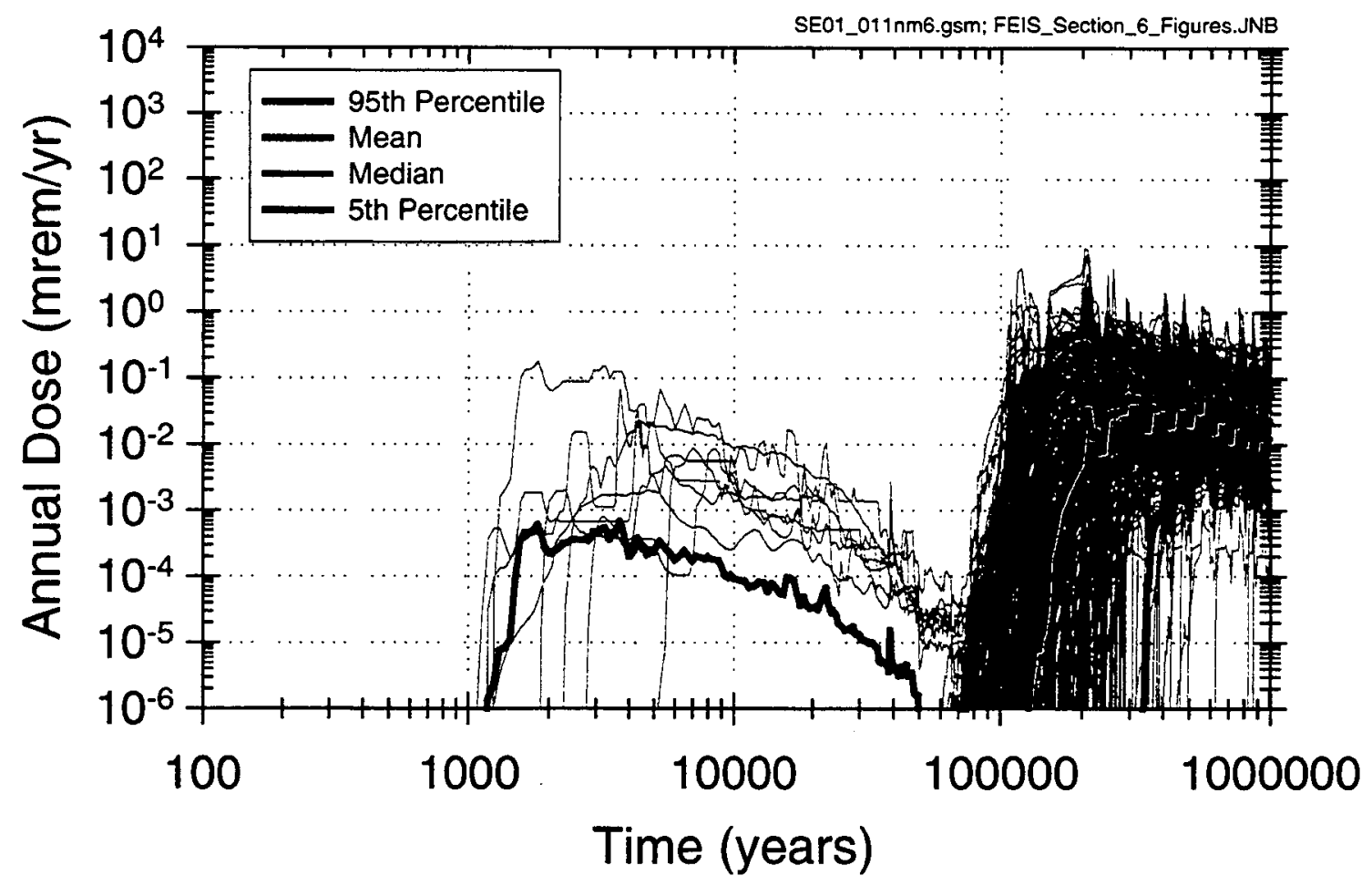

Figure 6-8 Annual Dose versus Time for 300 Probabilistic Simulations of the Module 2 Expanded Inventory for the HTOM at the RMEI Location Downgradient from a Repository. The Figure Displays the Results for Each Simulation and the $5^{\text {th }}$ and $95^{\text {th }}$ Percentiles, and the Mean and Median of these Simulations. 
Analyses for Disposal of Commercial and DOE Waste Inventories at Yucca Mountain - Input to Final Environmental Impact Statement and Site Suitability Evaluation

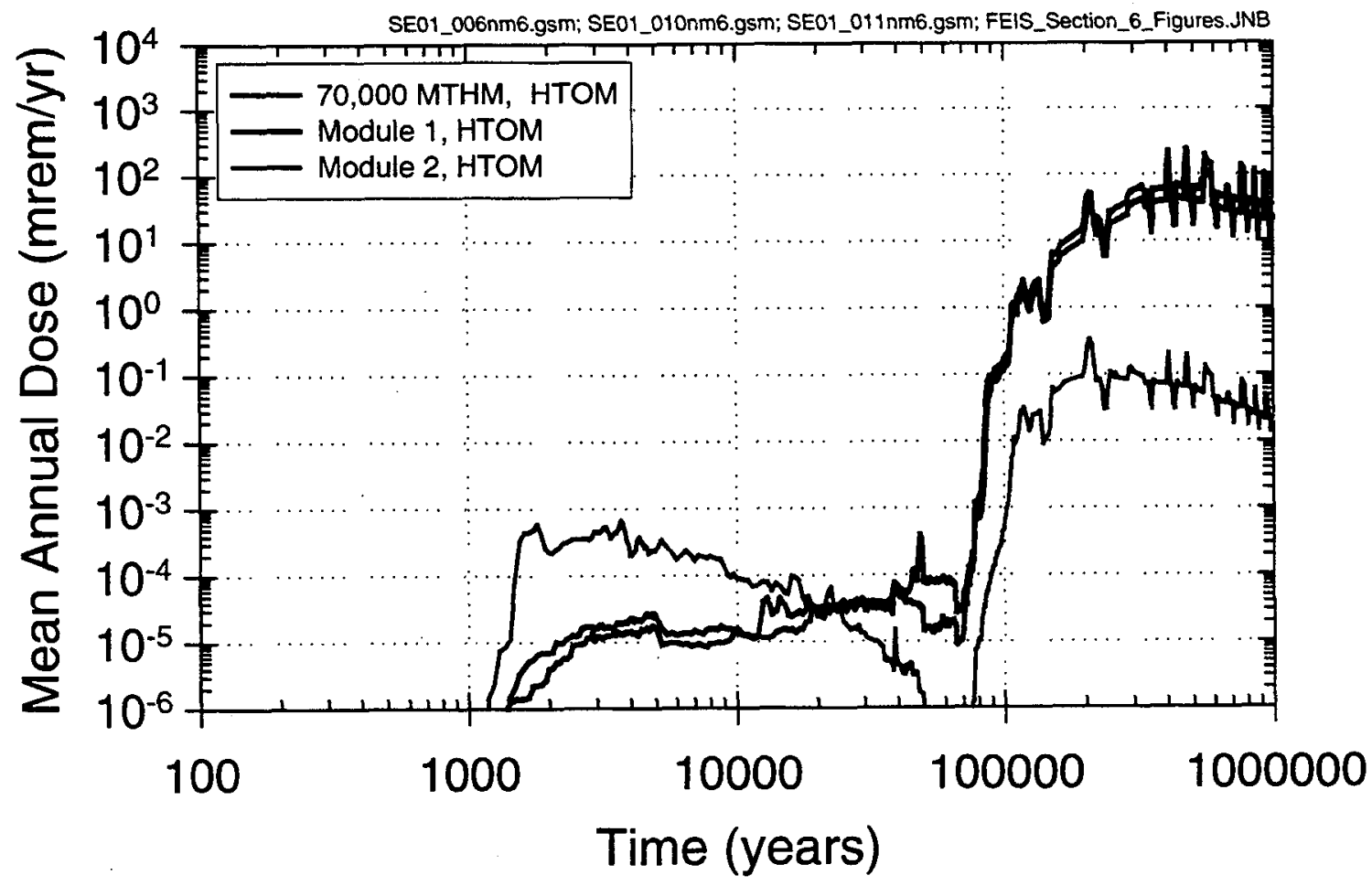

Figure 6-9 Comparison Plot of the Mean Annual Dose versus Time for HTOM for the 70,000-MTHM, Module 1 and Module 2 Inventories at the RMEl location Downgradient from a Repository 
Analyses for Disposal of Commercial and DOE Waste Inventories at Yucca Mountain - Input to Final Environmental Impact Statement and Site Suitability Evaluation

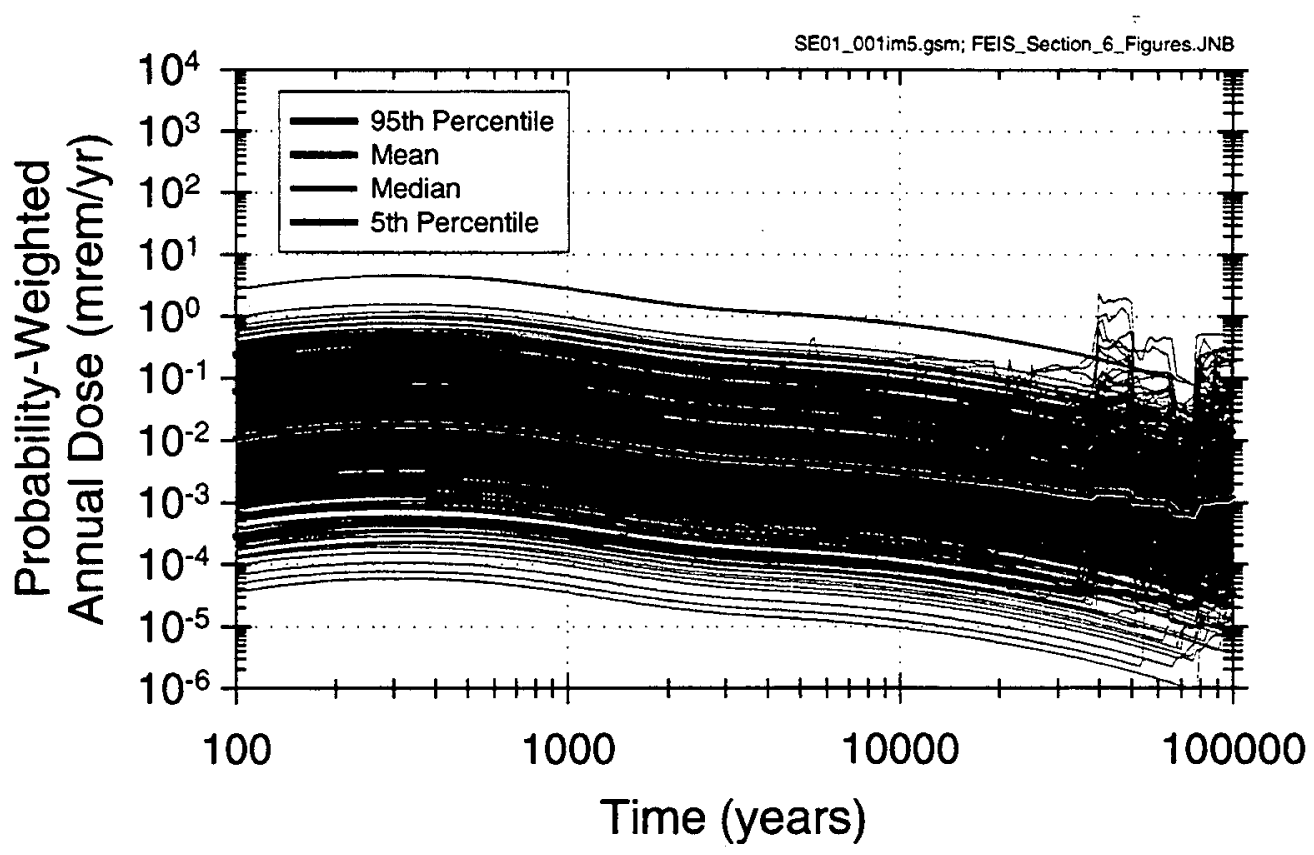

Figure 6-10a Annual Dose versus Time for 500 of 5000 Probabilistic Simulations of the Igneous Activity Scenario, including both Intrusive and Eruptive Events, for the 70,000-MTHM Inventory for the HTOM at the RMEl Location Downgradient from a Repository. The Figure Displays the Results for Each Simulation and the $5^{\text {th }}$ and $95^{\text {th }}$ Percentiles, and the Mean and Median of these Simulations. 


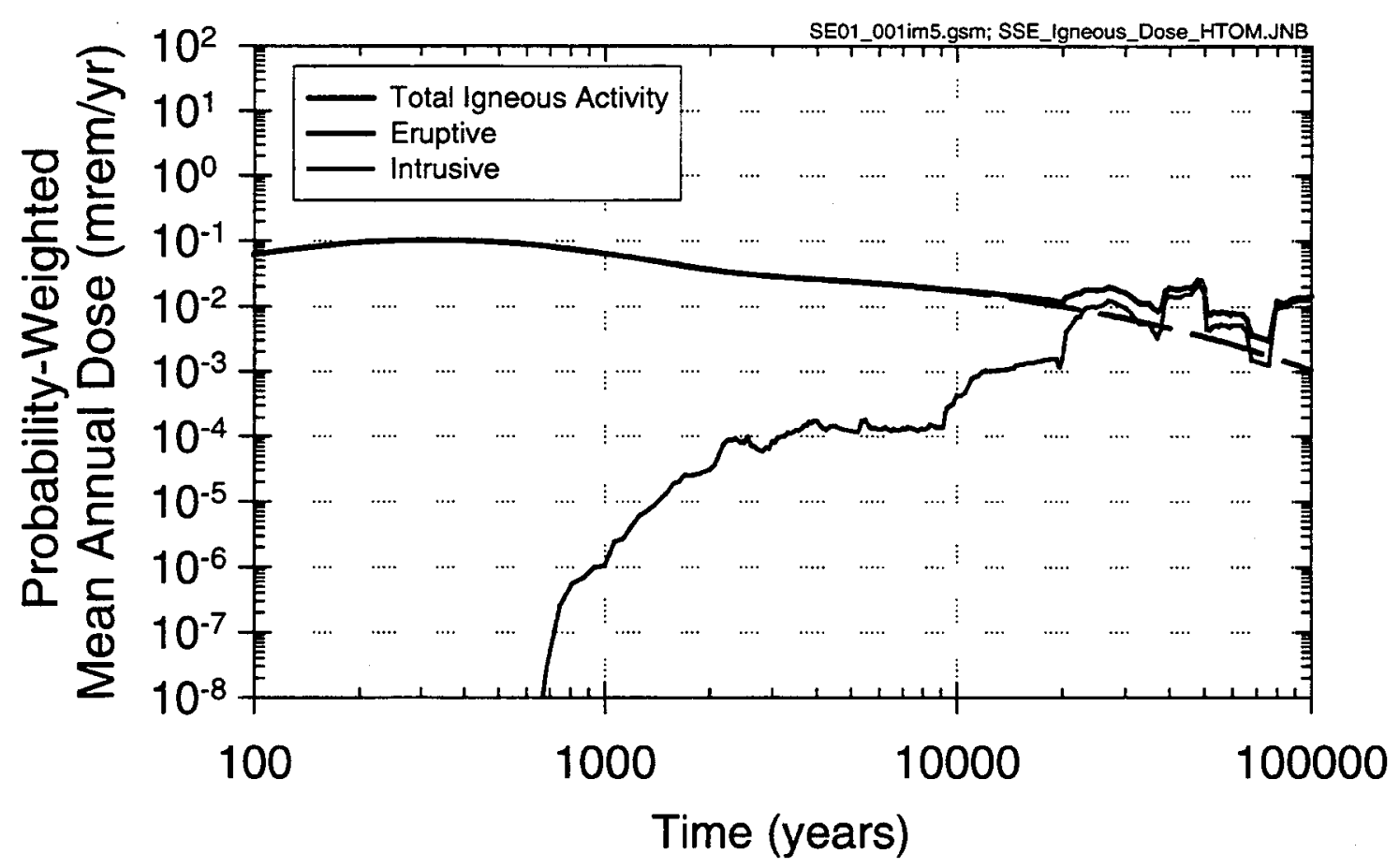

Figure 6-10b Mean Annual Dose versus Time for the Igneous Activity Scenario for the 70,000-MTHM Inventory for the HTOM at the RMEI Location Downgradient from a Repository. The Figure Displays the Mean Results for Both the Eruptive and Intrusive Events and the Sum of these Events as "Total Igneous". 


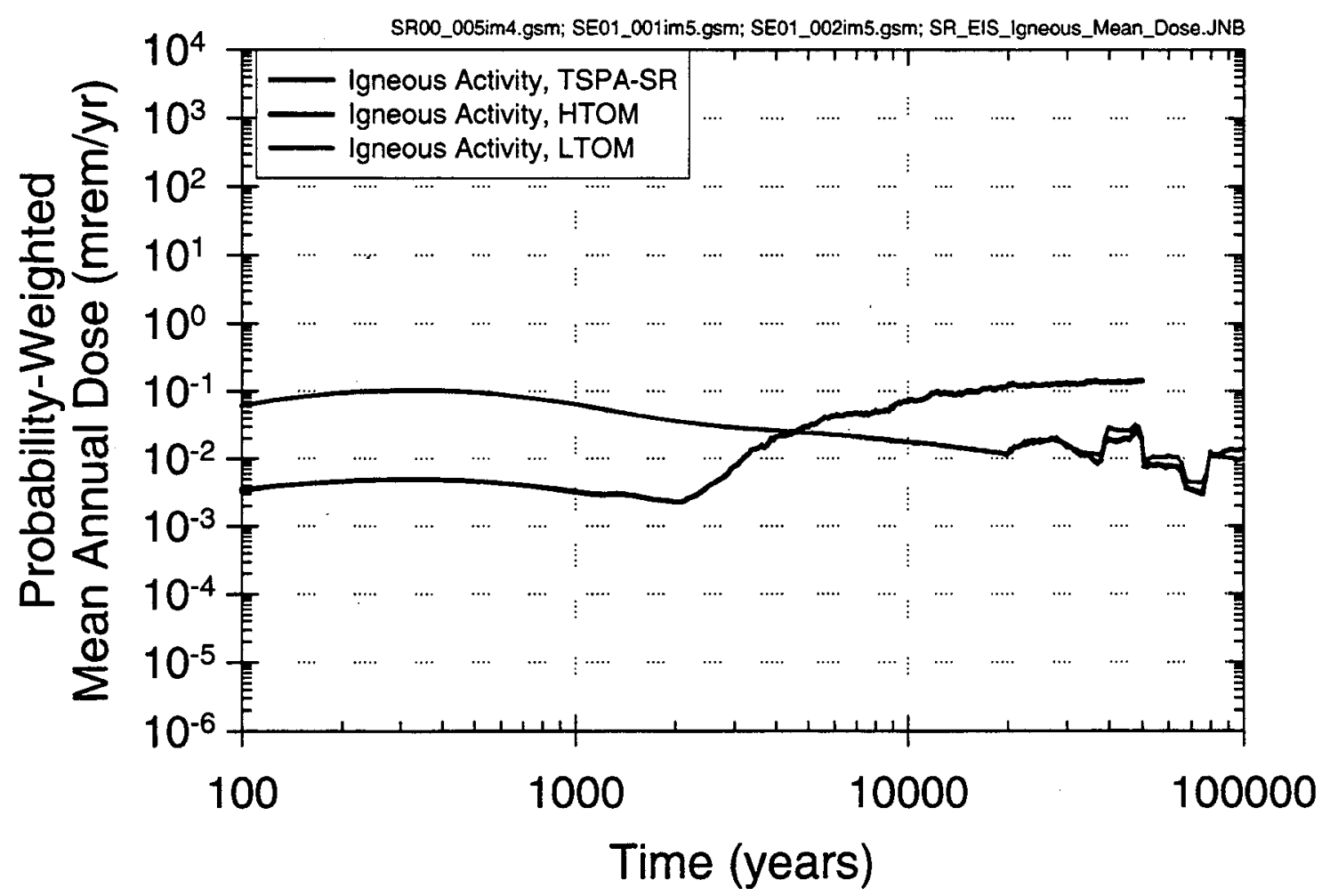

Figure 6-10c Mean Annual Dose versus Time for the Total Igneous Activity Scenario, which includes the Sum of the Igneous and Eruptive Events, for the TSPA-SR, HTOM, and the HTOM and LTOM for the 70,000-MTHM Inventory for this Letter Report at the RMEl Location Downgradient from a Repository. 
Analyses for Disposal of Commercial and DOE Waste Inventories at Yucca Mountain - Input to Final Environmental Impact Statement and Site Suitability Evaluation

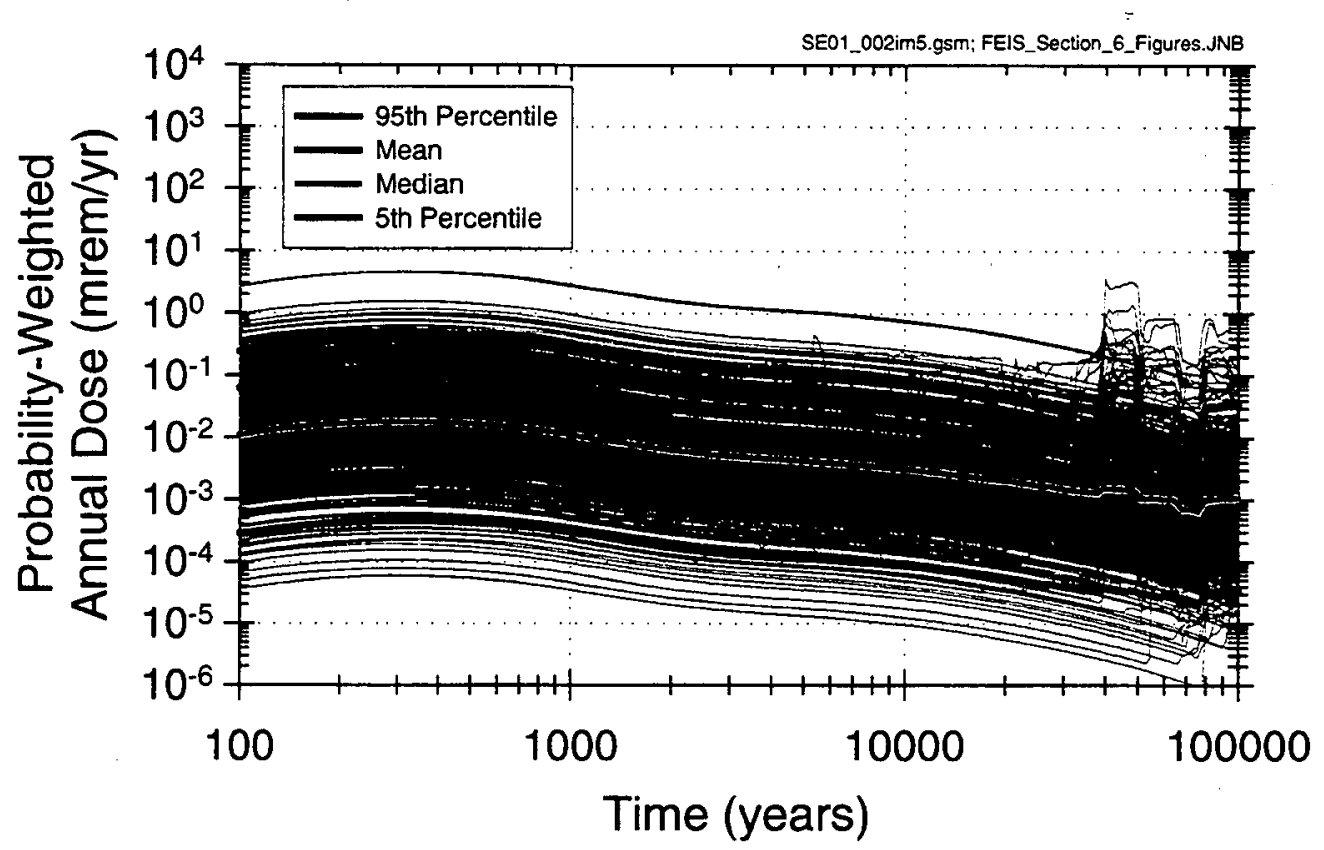

Figure 6-11a Annual Dose versus Time for 500 of 5000 Probabilistic Simulations of the Igneous Activity Scenario, including both Intrusive and Eruptive Events, for the70,000-MTHM Inventory for the LTOM at the RMEI Location Downgradient from a Repository. The Figure Displays the Results for Each Simulation and the $5^{\text {th }}$ and $95^{\text {th }}$ Percentiles, and the Mean and Median of these Simulations. 


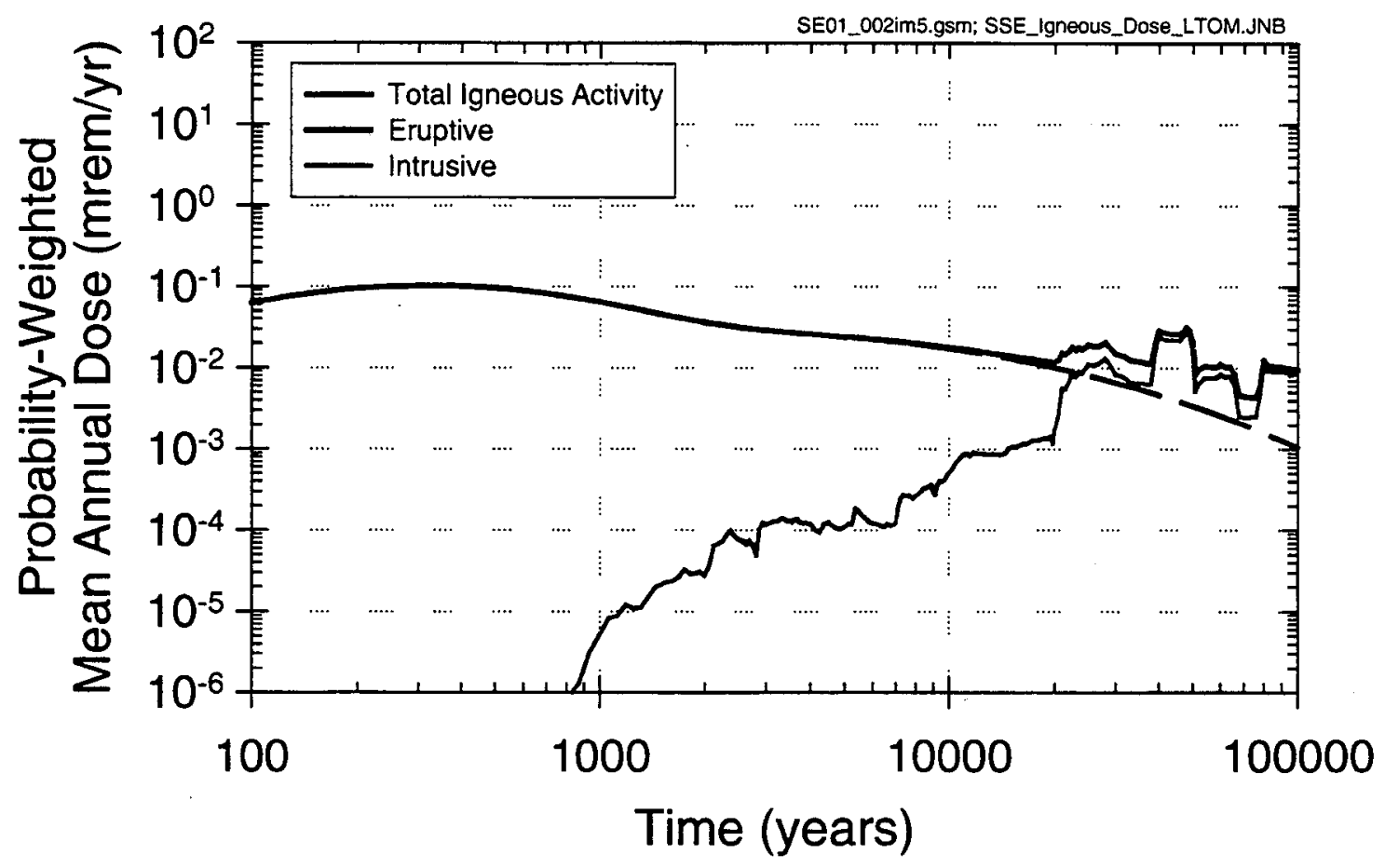

Figure 6-11b Mean Annual Dose versus Time for the Igneous Activity Scenario for the 70,000-MTHM Inventory for the LTOM at the RMEI Location Downgradient from a Repository. The Figure Displays the Mean Results for Both the Eruptive and Intrusive Events and the Sum of these Events as "Total Igneous". 
Analyses for Disposal of Commercial and DOE Waste Inventories at Yucca Mountain - Input to Final Environmental Impact Statement and Site Suitability Evaluation

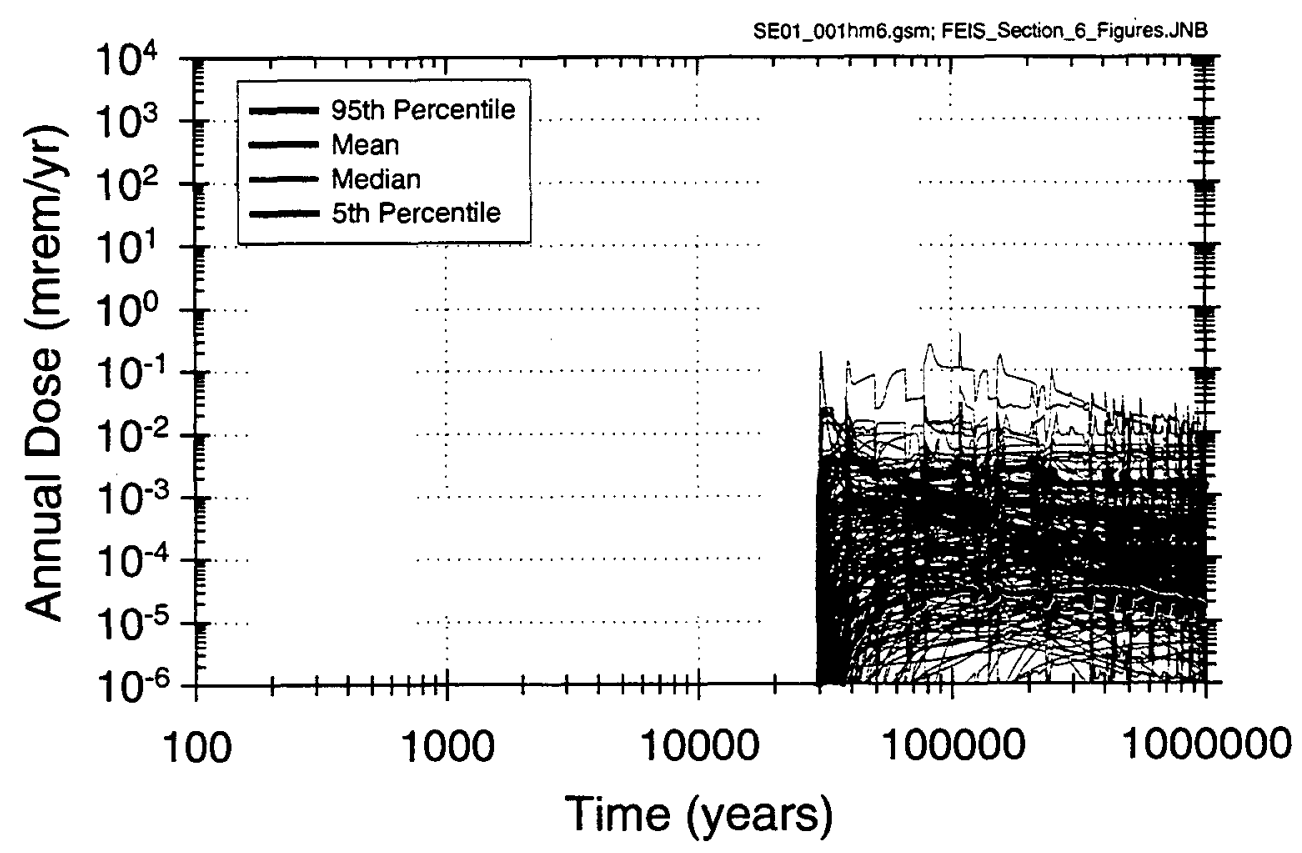

Figure 6-12 Annual Dose versus Time for the HTOM for the 30,000 year Human Intrusion Scenario for the 70,000-MTHM Inventory at the RMEl Location Downgradient from a Yucca Mountain Repository. The Figure Displays the Results of Each Simulation and the $5^{\text {th }}$ and $95^{\text {th }}$ Percentiles, and the Mean and Median of these Simulations 
Analyses for Disposal of Commercial and DOE Waste Inventories at Yucca Mountain - Input to Final Environmental Impact Statement and Site Suitability Evaluation

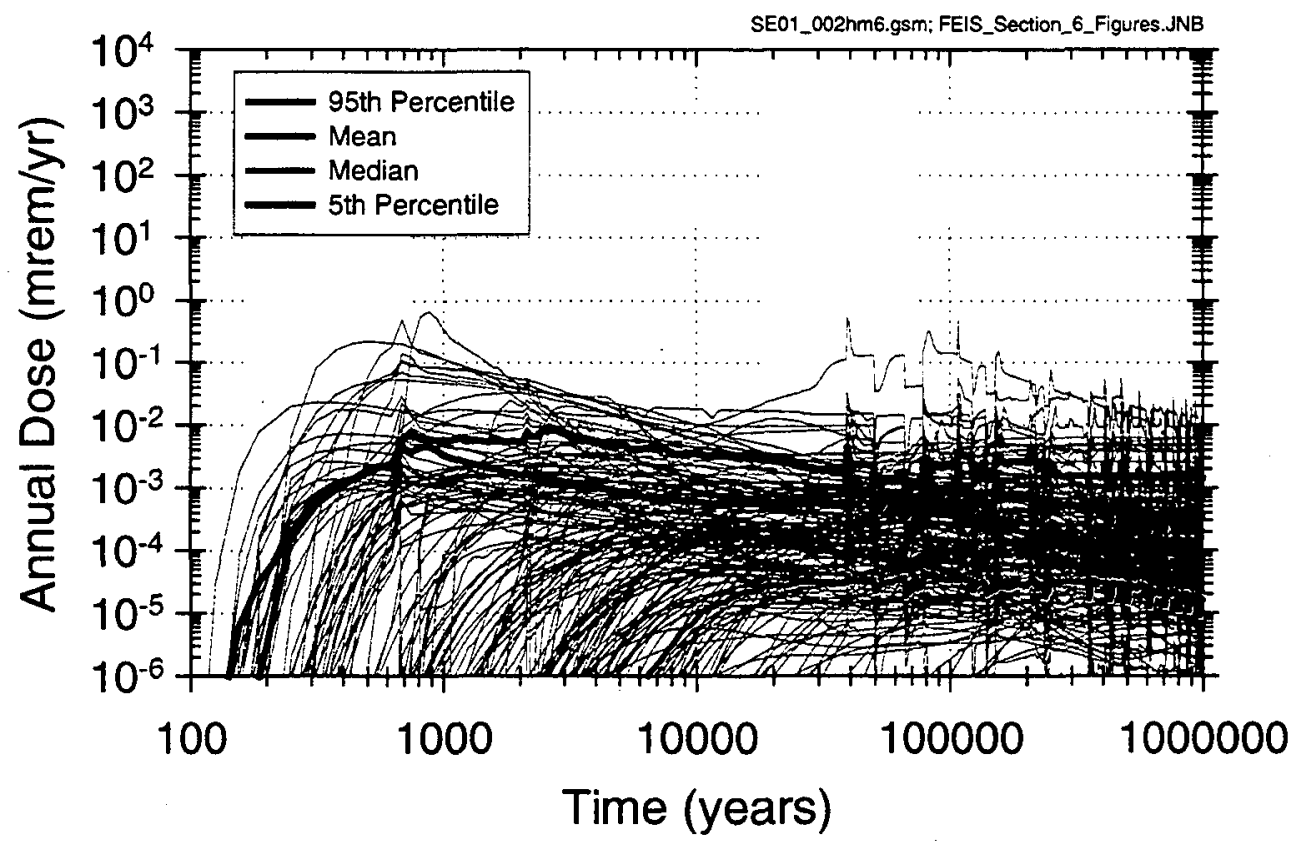

Figure 6-13 Annual Dose versus Time for 300 Probabilistic Simulations of the 100 year HumanIntrusion Scenario for the 70,000-MTHM Inventory for the HTOM at the RMEI Location Downgradient from a Repository. The Figure Displays the Results for Each Simulation and the $5^{\text {th }}$ and $95^{\text {th }}$ Percentiles, and the Mean and Median of these Simulations. 
Analyses for Disposal of Commercial and DOE Waste Inventories at Yucca Mountain - Input to Final Environmental Impact Statement and Site Suitability Evaluation

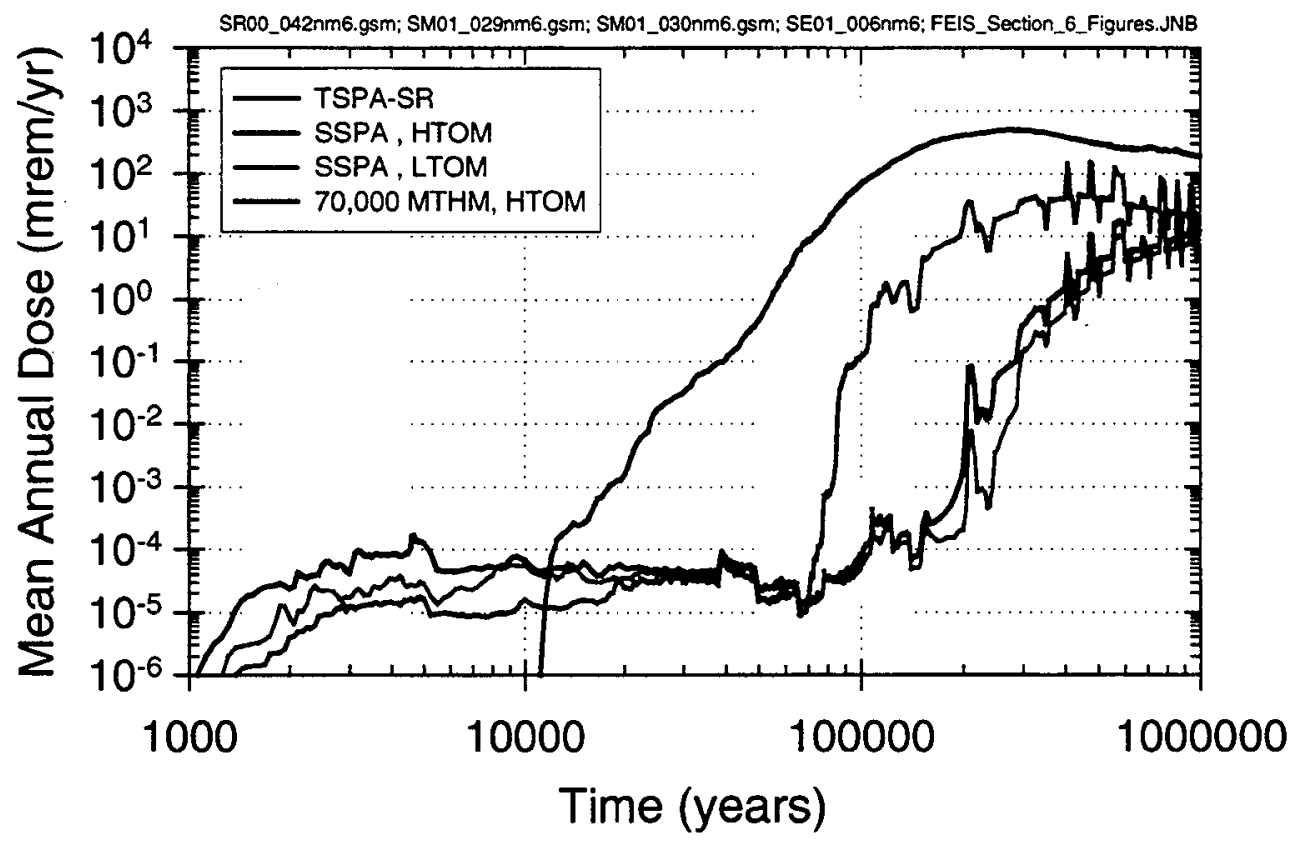

Figure 6-14 Comparison of the Mean Annual Dose versus Time for the 70,000-MTHM Inventory, the TSPA-SR Case, and the SSPA Case, both HTOM and LTOM 
Analyses for Disposal of Commercial and DOE Waste Inventories at Yucca Mountain - Input to Final Environmental Impact Statement and Site Suitability Evaluation

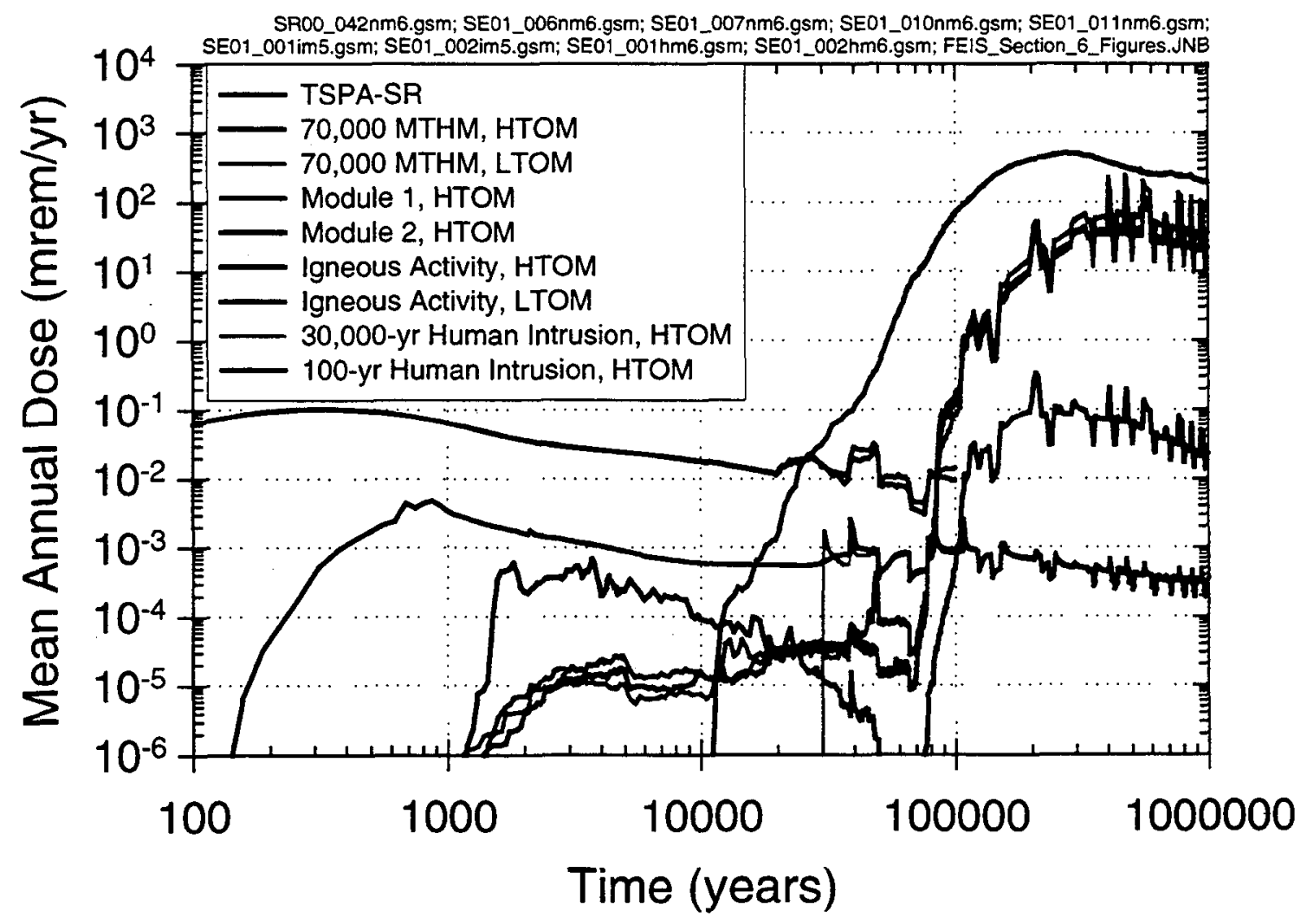

Figure 6-15 Comparison of the Annual Dose versus Time for the 70,000 MTHM Inventory, HTOM and LTOM, the Module 1 Inventory, HTOM, the Module 2 Inventory, HTOM, the IgneousActivity Scenario, HTOM and LTOM, the 30,000-yr and 100-yr Human-Intrusion Scenarios, HTOM, and the TSPA-SR Case, HTOM 
Analyses for Disposal of Commercial and DOE Waste Inventories at Yucca Mountain - Input to Final Environmental Impact Statement and Site Suitability Evaluation

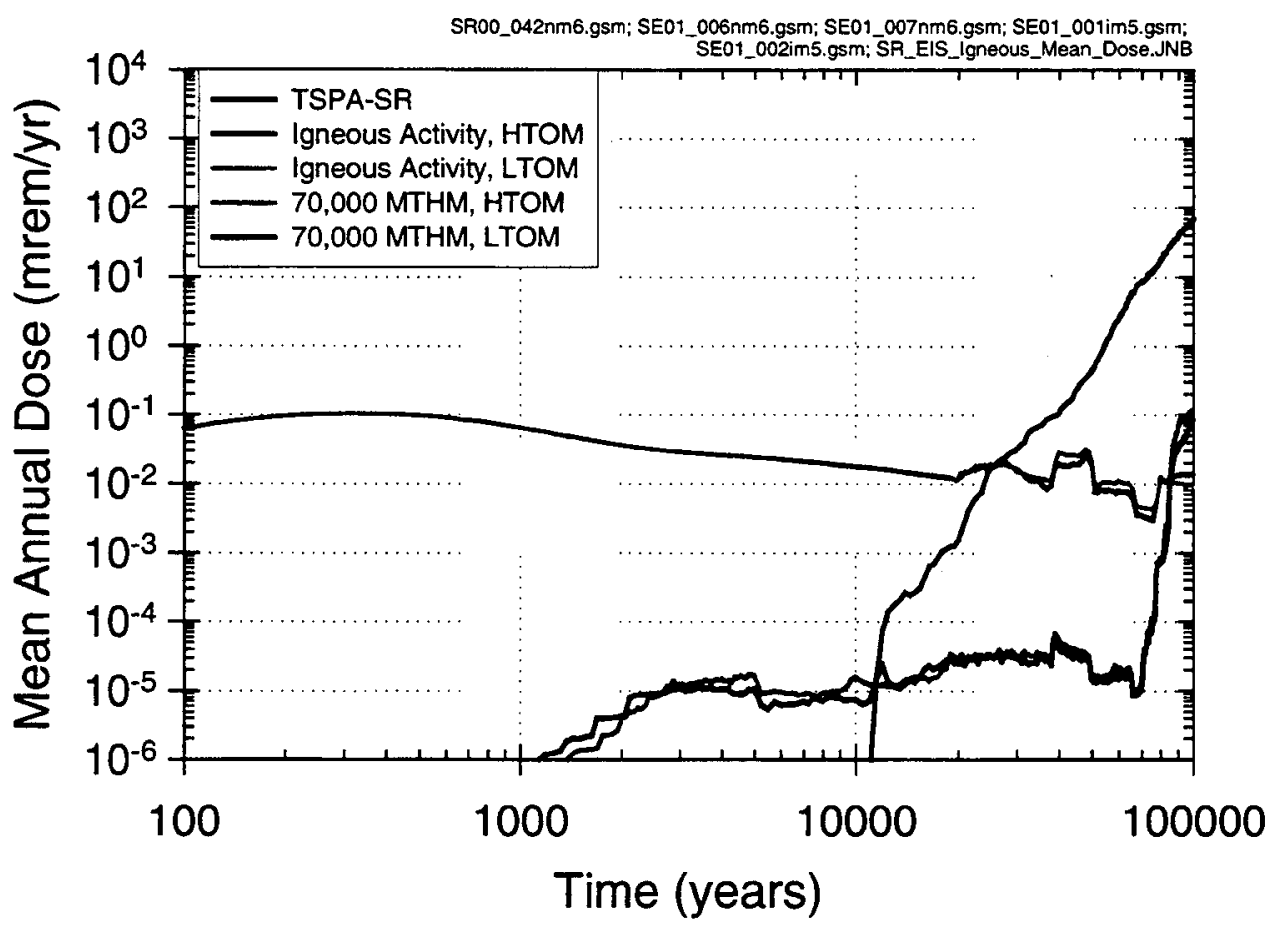

Figure 6-16 Comparison of the Annual Dose versus Time for the 70,000 MTHM Inventory, HTOM and LTOM, the Igneous-Activity Scenario, HTOM and LTOM, and the TSPA-SR Case, HTOM for the 100,000-year Performance Period 
Analyses for Disposal of Commercial and DOE Waste Inventories at Yucca Mountain - Input to Final Environmental Impact Statement and Site Suitability Evaluation

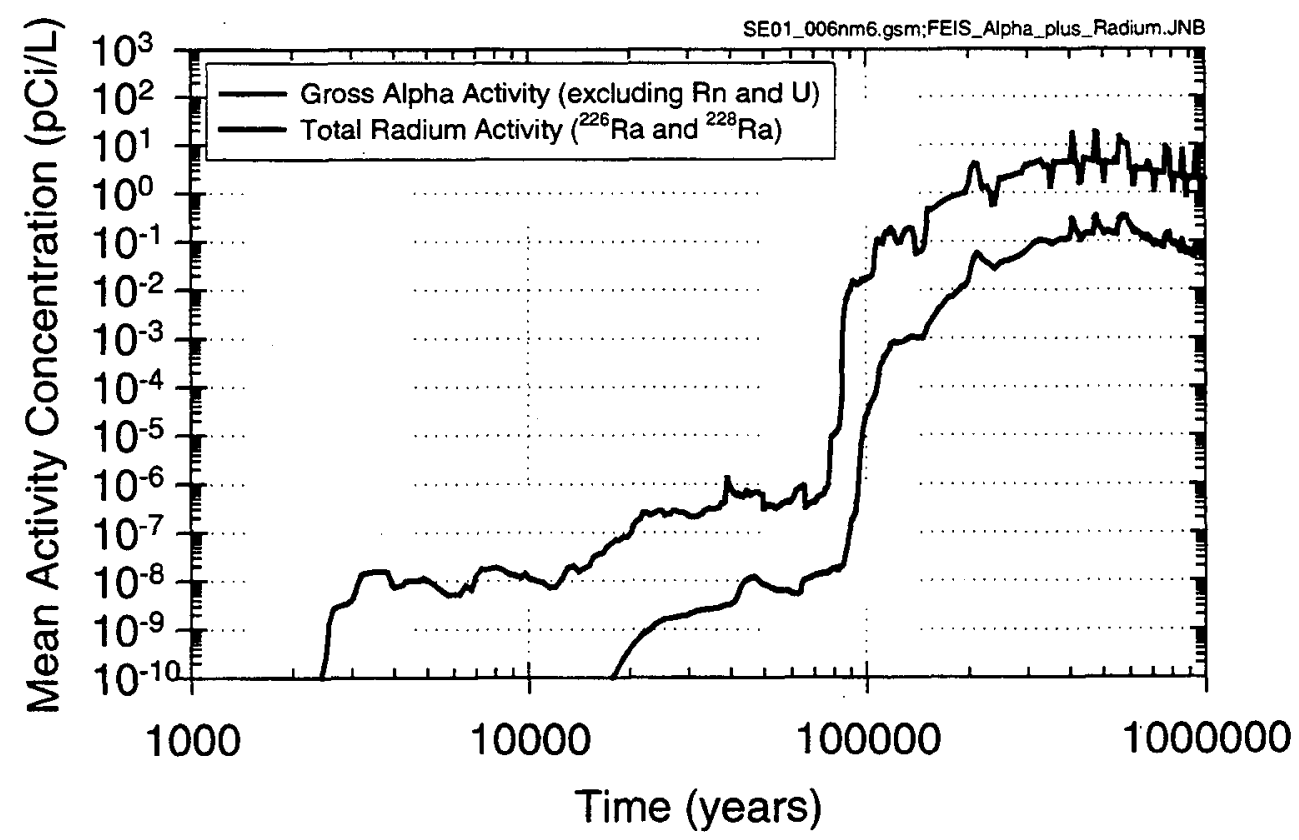

Figure 6-17 Mean Activity Concentrations of Gross Alpha Activity and Total Radium $\left({ }^{226}\right.$ Ra plus $\left.{ }^{228} \mathrm{Ra}\right)$ for the 70,000 MTHM Inventory, HTOM. The Concentrations are Calculated for a Representative Volume of Groundwater of 3,000 acre-feet at the Accessible Environment, Which is the Same as the RMEI Location. 
Analyses for Disposal of Commercial and DOE Waste Inventories at Yucca Mountain - Input to Final Environmental Impact Statement and Site Suitability Evaluation

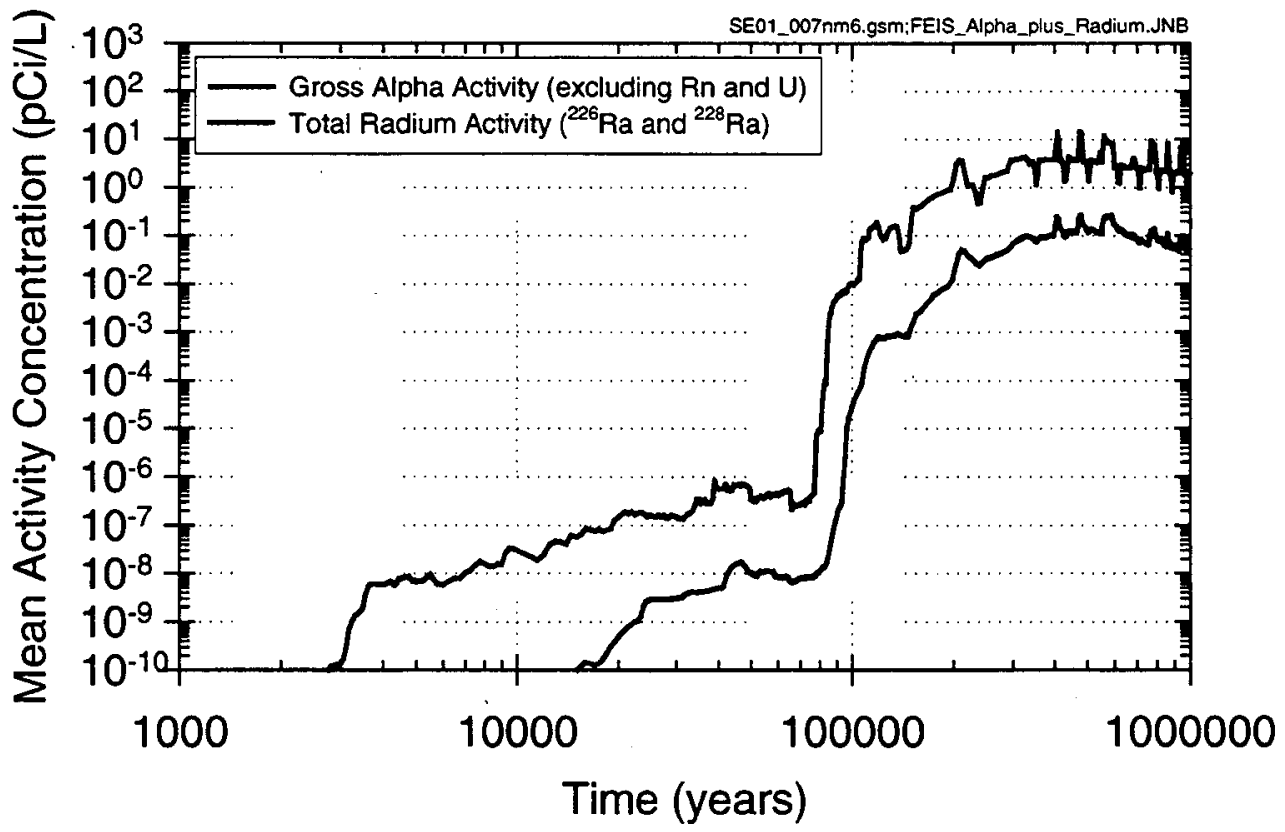

Figure 6-18 Mean Activity Concentrations of Gross Alpha Activity and Total Radium $\left({ }^{226}\right.$ Ra plus ${ }^{228}$ Ra) for the 70,000 MTHM Inventory, LTOM. The Concentrations are Calculated for a Representative Volume of Groundwater of 3,000 acre-feet at the Accessible Environment, Which is the Same as the RMEI Location. 


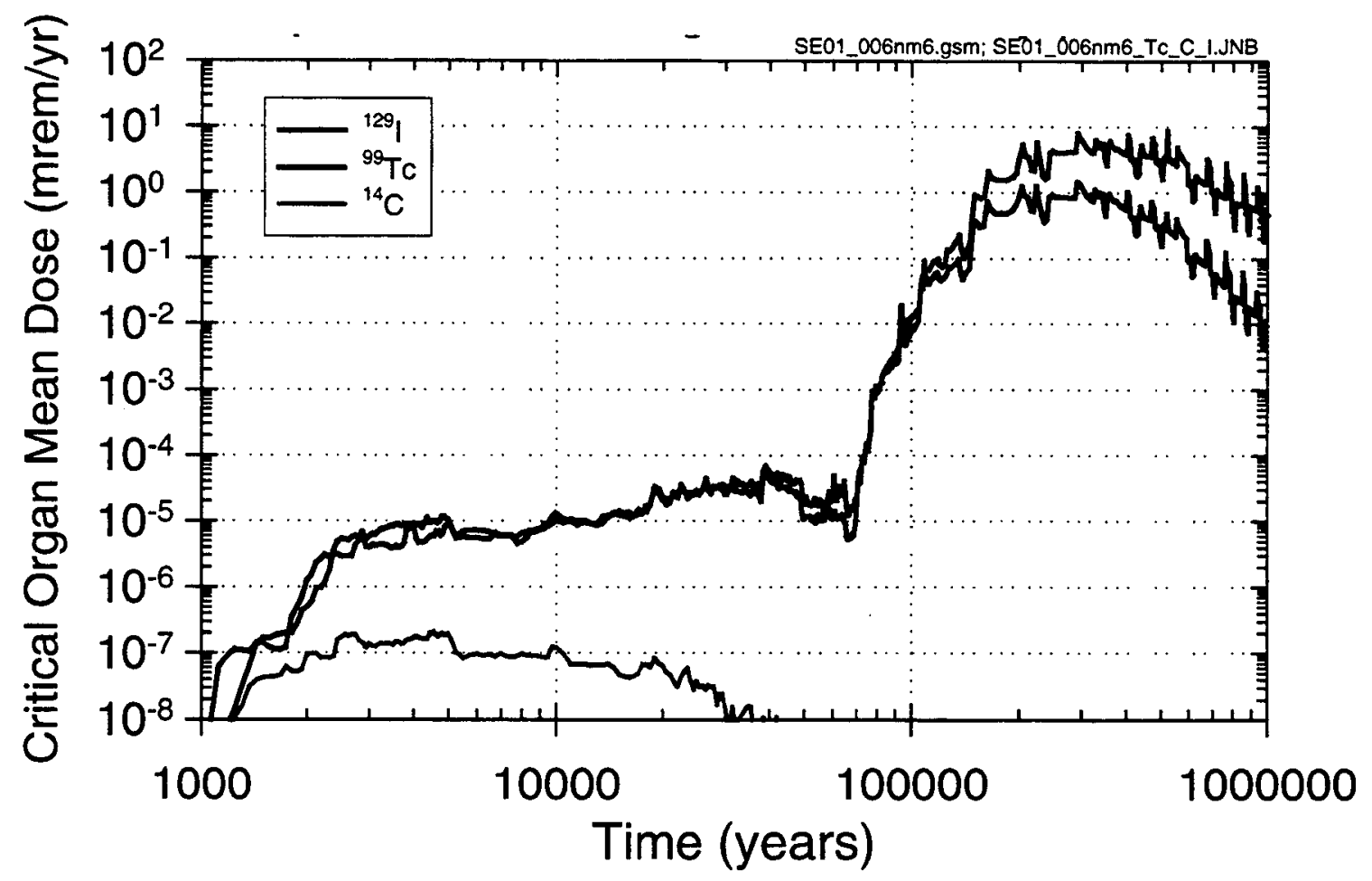

Figure 6-19 Mean Dose to Critical Organs for ${ }^{99} \mathrm{Tc},{ }^{14} \mathrm{C}$, and ${ }^{129} /$ for the $70,000 \mathrm{MTHM}$ Inventory, HTOM. The Concentrations are Calculated for a Representative Volume of Groundwater of 3,000 acre-feet at the Accessible Environment, Which is the Same as the RMEI Location. 


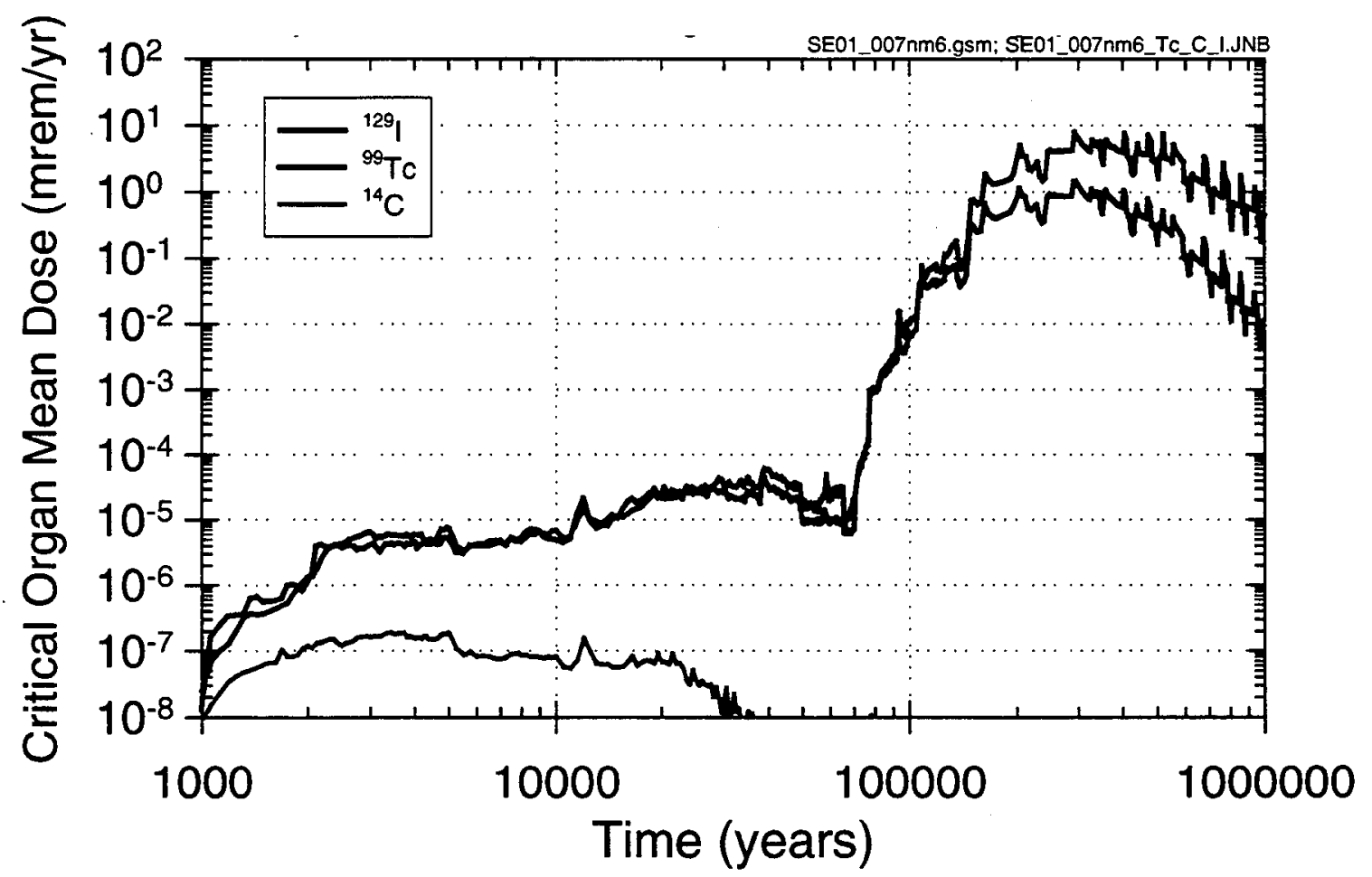

Figure 6-20 Mean Dose to Critical Organs for ${ }^{99} \mathrm{Tc},{ }^{14} \mathrm{C}$, and ${ }^{129} \mathrm{I}$ for the $70,000 \mathrm{MTHM}$ Inventory, LTOM. The Concentrations are Calculated for a Representative Volume of Groundwater of 3,000 acre-feet at the Accessible Environment, Which is the Same as the RMEI Location. 
Analyses for Disposal of Commercial and DOE Waste Inventories at Yucca Mountain - Input to Final Environmental Impact Statement and Site Suitability Evaluation

ATTACHMENT I

ACRONYMS AND ABBREVIATIONS 


\section{ACRONYMS AND ABBREVIATIONS}

\begin{tabular}{|c|c|}
\hline $\mathrm{AMCG}$ & average member of the critical group \\
\hline AMR & Analysis Model Report \\
\hline BSC & Bechtel SAIC Company, LLC \\
\hline CFR & Code of Federal Regulations \\
\hline CRWMS & Civilian Radioactive Waste Management System \\
\hline CSCI & Computer Software Configuration Item \\
\hline CSNF & Commercial Spent Nuclear Fuel \\
\hline DIRS & Document Input Reference System \\
\hline DOE & U.S. Department of Energy \\
\hline DSNF & DOE Spent Nuclear Fuel \\
\hline EPA & U.S. Environmental Protection Agency \\
\hline EIS & Environmental Impact Statement \\
\hline FEHM & Finite Element Heat and Mass model \\
\hline FEIS & Final Environmental Impact Statement \\
\hline GTCC & Greater Than Class C \\
\hline HLW & High-Level Waste \\
\hline HTOM & high-temperature operating mode \\
\hline JTC & Jason Technologies Corporation \\
\hline LTOM & low-temperature operating mode \\
\hline MTHM & Metric Tons Heavy Metal \\
\hline $\mathrm{M} \& \mathrm{O}$ & Management and Operating Contractor \\
\hline NRC & Nuclear Regulatory Commission \\
\hline NUFT & Nonisothermal Unsaturated-saturated Flow and Transport model \\
\hline NWPA & Nuclear Waste Policy Act \\
\hline OCRWM & Office of Civilian Radioactive Waste Management \\
\hline REV & Revision \\
\hline RIP & Repository Integration Program \\
\hline RMEI & reasonably maximally exposed individual \\
\hline
\end{tabular}


Analyses for Disposal of Commercial and DOE Waste Inventories at Yucca Mountain - Input to Final Environmental Impact Statement and Site Suitability Evaluation

SSE

SNF

SPAR

SR

SSPA

STN

SZ

TSPA

$\mathrm{UZ}$
Site Suitability Evaluation

Spent Nuclear Fuel

Special Performance Assessment Required

Site Recommendation

Supplemental Science and Performance Analysis

Software Tracking Number

Saturated Zone

Total System Performance Assessment

Unsaturated Zone 
Analyses for Disposal of Commercial and DOE Waste Inventories at Yucca Mountain - Input to Final Environmental Impact Statement and Site Suitability Evaluation

\section{ATTACHMENT II}

\section{Extraction of Repository Release Nodes}


Analyses for Disposal of Commercial and DOE Waste Inventories at Yucca Mountain - Input to Final Environmental Impact Statement and Site Suitability Evaluation

The following describes the procedures used to calculate the new fraction of the repository area for each infiltration-rate bin for the simulation of the EIS Expanded-inventory case.

The fraction of the repository area occupied by each infiltration-ate bin for the expandedinventory case was calculated to determine adequate area assignments. In the TSPA-SR basecase analysis ([DIRS 153246], all), the fraction of repository area for each infiltration-rate bin is known. This information is presented in Table II-1. The data are tracked by DTN: LL000114004242.090, LL000114104242.091, and LL000113904242.089.

Table II-1 Infiltration-rate bin Fractional Areas: 70,000-MTHM Inventory

\begin{tabular}{|c|c|c|c|}
\hline $\begin{array}{c}\text { Bin } \\
\text { Number }\end{array}$ & $\begin{array}{c}\text { Low } \\
\text { Infiltration }\end{array}$ & $\begin{array}{c}\text { Mean } \\
\text { Infiltration }\end{array}$ & $\begin{array}{c}\text { High } \\
\text { Infiltration }\end{array}$ \\
\hline 1 & 0.597 & 0.016 & 0 \\
\hline 2 & 0.403 & 0.132 & 0.012 \\
\hline 3 & 0 & 0.321 & 0.134 \\
\hline 4 & 0 & 0.529 & 0.548 \\
\hline 5 & 0 & 0.003 & 0.306 \\
\hline Total & 1 & 1.001 & 1 \\
\hline
\end{tabular}

For the current analysis, this information has been updated. The updated repository fractions were contained in a series of thermal hydrology files describing environmental parameters in the Near Field Environment. There were two sets of Infiltration-rate bin Fractional Areas, one for the High Temperature Operating Mode (HTOM) and one for the Low Temperature Operating Mode (LTOM). These data are presented in Tables II- $2 a$ and II-2b, respectively.

Table II-2a Infiltration-rate bin Fractional Areas: 70,000-MTHM Inventory, HTOM

\begin{tabular}{|c|c|c|c|}
\hline $\begin{array}{c}\text { Bin } \\
\text { Number }\end{array}$ & $\begin{array}{c}\text { Low } \\
\text { Infiltration }\end{array}$ & $\begin{array}{c}\text { Mean } \\
\text { Infiltration }\end{array}$ & $\begin{array}{c}\text { High } \\
\text { Infiltration }\end{array}$ \\
\hline 1 & 0.6955 & 0 & 0 \\
\hline 2 & 0.3045 & 0.0601 & 0.0104 \\
\hline 3 & 0 & 0.3243 & 0.0587 \\
\hline 4 & 0 & 0.6156 & 0.6687 \\
\hline 5 & 0 & 0 & 0.2622 \\
\hline Total & 1 & 1 & 1 \\
\hline
\end{tabular}

Table II-2b Infiltration-rate bin Fractional Areas: 70,000-MTHM Inventory, LTOM

\begin{tabular}{|c|c|c|c|}
\hline $\begin{array}{c}\text { Bin } \\
\text { Number }\end{array}$ & $\begin{array}{c}\text { Low } \\
\text { Infiltration }\end{array}$ & $\begin{array}{c}\text { Mean } \\
\text { Infiltration }\end{array}$ & $\begin{array}{c}\text { High } \\
\text { Infiltration }\end{array}$ \\
\hline 1 & 0.7441 & 0 & 0 \\
\hline 2 & 0.2559 & 0.1451 & 0.0087 \\
\hline 3 & 0 & 0.3394 & 0.1489 \\
\hline 4 & 0 & 0.5155 & 0.6236 \\
\hline 5 & 0 & 0 & 0.2188 \\
\hline Total & 1 & 1 & 1 \\
\hline
\end{tabular}


Analyses for Disposal of Commercial and DOE Waste Inventories at Yucca Mountain - Input to Final Environmental Impact Statement and Site Suitability Evaluation

The number of FEHM nodes assigned to each infiltration-rate bin under each infiltration scenario is known for both the 70,000 MTHM case and expanded-inventory case. The FEHM node distribution is identical for both the HTOM and LTOM cases and no distinction is made for the thermal mode. The number of FEHM nodes assigned to each infiltration-rate bin should approximate the mass distribution among the bins. The calculation of the repository area for the simulations for the expanded-inventory case was calculated using the 70,000-MTHM-inventory repository area distribution and the FEHM node placement proportions for the two scenarios.

The number of FEHM nodes for the 70,000 MTHM case was supplied in the text files glal1_EBS.zone, glam1_EBS.zone, and glau1_EBS.zone for the low, mean, and high infiltration scenarios, respectively. The number of FEHM nodes for the low-infiltration case are found on line 3 for Bin 1, line 33 for Bin 2, line 43 for Bin 3, line 47 for Bin 4, and line 51 for Bin 5 . The number of FEHM nodes for the mean-infiltration case are found on line 3 for Bin 1, line 13 for Bin 2, line 22 for Bin 3, line 35 for Bin 4, and line 51 for Bin 5. The number of FEHM nodes for the high-infiltration case are found on line 3 for Bin 1, line 12 for Bin 2, line 18 for Bin 3, line 25 for Bin 4, and line 43 for Bin 5. The number of nodes per bin for the 70,000-MTHM case inventory is presented in Table II-3a. The contribution of FEHM nodes from infiltration-rate bins that do not account for any of the fractional bin areas was removed. The adjusted number of nodes per bin for the 70,000-MTHM case is presented in Table II-3b.

Table II-3a Number of FEHM Nodes in Each Infiltration-rate bin: 70,000-MTHM Inventory

\begin{tabular}{|c|c|c|c|}
\hline $\begin{array}{c}\text { Bin } \\
\text { Number }\end{array}$ & $\begin{array}{c}\text { Low } \\
\text { Infiltration }\end{array}$ & $\begin{array}{c}\text { Mean } \\
\text { Infiltration }\end{array}$ & $\begin{array}{c}\text { High } \\
\text { Infiltration }\end{array}$ \\
\hline 1 & 216 & 51 & 43 \\
\hline 2 & 53 & 42 & 23 \\
\hline 3 & 4 & 78 & 32 \\
\hline 4 & 2 & 98 & 115 \\
\hline 5 & 0 & 6 & 62 \\
\hline Total & 275 & 275 & 275 \\
\hline
\end{tabular}

Table II-3b Adjusted Number of FEHM Nodes in Each Infiltration-rate bin: 70,000-MTHM Inventory

\begin{tabular}{|c|c|c|c|}
\hline $\begin{array}{c}\text { Bin } \\
\text { Number }\end{array}$ & $\begin{array}{c}\text { Low } \\
\text { Infiltration }\end{array}$ & $\begin{array}{c}\text { Mean } \\
\text { Infiltration }\end{array}$ & $\begin{array}{c}\text { High } \\
\text { Infiltration }\end{array}$ \\
\hline 1 & 216 & 0 & 0 \\
\hline 2 & 53 & 42 & 23 \\
\hline 3 & 0 & 78 & 32 \\
\hline 4 & 0 & 98 & 115 \\
\hline 5 & 0 & 0 & 62 \\
\hline Total & 269 & 218 & 232 \\
\hline
\end{tabular}

The fraction of the resulting total of FEHM nodes was calculated for each bin. The results are presented in Table II-4. 
Analyses for Disposal of Commercial and DOE Waste Inventories at Yucca Mountain - Input to Final Environmental Impact Statement and Site Suitability Evaluation

Table II-4 Fraction of FEHM Nodes in Each Infiltration-rate bin: 70,000-MTHM Inventory

\begin{tabular}{|c|c|c|c|}
\hline $\begin{array}{c}\text { Bin } \\
\text { Number }\end{array}$ & $\begin{array}{c}\text { Low } \\
\text { Infiltration }\end{array}$ & $\begin{array}{c}\text { Mean } \\
\text { Infiltration }\end{array}$ & $\begin{array}{c}\text { High } \\
\text { Infiltration }\end{array}$ \\
\hline 1 & 0.8030 & 0 & 0 \\
\hline 2 & 0.1970 & 0.1927 & 0.0991 \\
\hline 3 & 0 & 0.3578 & 0.1379 \\
\hline 4 & 0 & 0.4495 & 0.4957 \\
\hline 5 & 0 & 0 & 0.2672 \\
\hline Total & 1 & 1 & 1 \\
\hline
\end{tabular}

The number of FEHM nodes for the expanded inventory was supplied in the text files glal1_EBS_EIS.zone, glam1_EBS_EIS.zone, and glau1_EBS_EIS.zone for the low-, mean-, and high-infiltration scenarios, respectively. The number of $\bar{F} E H M$ nodes for the low-infiltration case are found on line 3 for Bin 1, line 62 for Bin 2, line 73 for Bin 3, line 77 for Bin 4, and line 81 for Bin 5. The number of FEHM nodes for the mean-infiltration case are found on line 3 for Bin 1, line 17 for Bin 2, line 27 for Bin 3, line 42 for Bin 4, and line 60 for Bin 5. The number of FEHM nodes for the high-infiltration case are found on line 3 for Bin 1, line 15 for Bin 2, line 22 for Bin 3, line 30 for Bin 4, and line 49 for Bin 5 . The number of nodes per bin for the expanded-inventory case is presented in Table II-5.

Table II-5 Number of FEHM Nodes in Each Infiltration-rate bin: Expanded Inventory

\begin{tabular}{|c|c|c|c|}
\hline $\begin{array}{c}\text { Bin } \\
\text { Number }\end{array}$ & $\begin{array}{c}\text { Low } \\
\text { Infiltration }\end{array}$ & $\begin{array}{c}\text { Mean } \\
\text { Infiltration }\end{array}$ & $\begin{array}{c}\text { High } \\
\text { Infiltration }\end{array}$ \\
\hline 1 & 281 & 84 & 71 \\
\hline 2 & 59 & 51 & 30 \\
\hline 3 & 3 & 89 & 40 \\
\hline 4 & 2 & 113 & 128 \\
\hline 5 & 0 & 8 & 76 \\
\hline Total & 345 & 345 & 345 \\
\hline
\end{tabular}

The node assignments were adjusted for bins that do not account for any of the repository area and the fraction of the total FEHM nodes was calculated for each bin. The results are presented in Table II-6.

Table II-6 Fraction of FEHM Nodes in Each Infiltration-rate bin: Expanded Inventory

\begin{tabular}{|c|c|c|c|}
\hline $\begin{array}{c}\text { Bin } \\
\text { Number }\end{array}$ & $\begin{array}{c}\text { Low } \\
\text { Infiltration }\end{array}$ & $\begin{array}{c}\text { Mean } \\
\text { Infiltration }\end{array}$ & $\begin{array}{c}\text { High } \\
\text { Infiltration }\end{array}$ \\
\hline 1 & 0.8265 & 0 & 0 \\
\hline 2 & 0.1735 & 0.2016 & 0.1095 \\
\hline 3 & 0 & 0.3518 & 0.1460 \\
\hline 4 & 0 & 0.4466 & 0.4672 \\
\hline 5 & 0 & 0 & 0.2773 \\
\hline Total & 1 & 1 & 1 \\
\hline
\end{tabular}


Analyses for Disposal of Commercial and DOE Waste Inventories at Yucca Mountain - Input to Final Environmental Impact Statement and Site Suitability Evaluation

It was observed that the fraction of FEHM nodes in each bin is similar, so it was reasoned that the fraction of repository area should also be similar. To calculate the fraction of repository area for each infiltration bin in the expanded-inventory case, the fraction of the repository area for each bin for the 70,000-MTHM, HTOM and 70,000-MTHM LTOM cases (Tables 2a and $2 b$, respectively) were multiplied by the fraction of FEHM nodes for the expanded-inventory case (Table 6). This value was then divided by the fraction of FEHM nodes for the 70,000-MTHM inventory case (Table 4). This proportional calculation, based on FEHM node distribution, yielded the values presented in Table II-7a and II-7b.

Table II-7a Proportional Fraction of the Repository Area in Each Infiltration-rate bin: Expanded Inventory, HTOM

\begin{tabular}{|c|c|c|c|}
\hline $\begin{array}{c}\text { Bin } \\
\text { Number }\end{array}$ & $\begin{array}{c}\text { Low } \\
\text { Infiltration }\end{array}$ & $\begin{array}{c}\text { Mean } \\
\text { Infiltration }\end{array}$ & $\begin{array}{c}\text { High } \\
\text { Infiltration }\end{array}$ \\
\hline 1 & 0.7159 & 0 & 0 \\
\hline 2 & 0.2682 & 0.0629 & 0.0115 \\
\hline 3 & 0 & 0.3188 & 0.0621 \\
\hline 4 & 0 & 0.6116 & 0.6302 \\
\hline 5 & 0 & 0 & 0.2721 \\
\hline Total & 0.9840 & 0.9934 & 0.9760 \\
\hline
\end{tabular}

Table II-7b Proportional Fraction of the Repository Area in Each Infiltration-rate bin: Expanded Inventory, LTOM

\begin{tabular}{|c|c|c|c|}
\hline $\begin{array}{c}\text { Bin } \\
\text { Number }\end{array}$ & $\begin{array}{c}\text { Low } \\
\text { Infiltration }\end{array}$ & $\begin{array}{c}\text { Mean } \\
\text { Infiltration }\end{array}$ & $\begin{array}{c}\text { High } \\
\text { Infiltration }\end{array}$ \\
\hline 1 & 0.7659 & 0 & 0 \\
\hline 2 & 0.2254 & 0.1518 & 0.0096 \\
\hline 3 & 0 & 0.3337 & 0.1576 \\
\hline 4 & 0 & 0.5122 & 0.5877 \\
\hline 5 & 0 & 0 & 0.2271 \\
\hline Total & 0.9913 & 0.9977 & 0.9820 \\
\hline
\end{tabular}

The values in Tables II-7a and II-7b were normalized by dividing by the sum totals. The results yield the calculated fraction of the repository area per infiltration-rate bin for the HTOM and LTOM simulations for the expanded-inventory case. These results are presented in Table II-8a and II-8b. 
Analyses for Disposal of Commercial and DOE Waste Inventories at Yucca Mountain - Input to Final Environmental Impact Statement and Site Suitability Evaluation

Table II-8a Normalized Fraction of the Repository Area in Each Infiltration-rate bin: Expanded Inventory, HTOM

\begin{tabular}{|c|c|c|c|}
\hline $\begin{array}{c}\text { Bin } \\
\text { Number }\end{array}$ & $\begin{array}{c}\text { Low } \\
\text { Infiltration }\end{array}$ & $\begin{array}{c}\text { Mean } \\
\text { Infiltration }\end{array}$ & $\begin{array}{c}\text { High } \\
\text { Infiltration }\end{array}$ \\
\hline 1 & 0.7275 & 0 & 0 \\
\hline 2 & 0.2725 & 0.0633 & 0.0118 \\
\hline 3 & 0 & 0.3210 & 0.0637 \\
\hline 4 & 0 & 0.6157 & 0.6457 \\
\hline 5 & 0 & 0 & 0.2788 \\
\hline Total & 1 & 1 & 1 \\
\hline
\end{tabular}

Table II-8b Normalized Fraction of the Repository Area in Each Infiltration-rate bin: Expanded Inventory, LTOM

\begin{tabular}{|c|c|c|c|}
\hline $\begin{array}{c}\text { Bin } \\
\text { Number }\end{array}$ & $\begin{array}{c}\text { Low } \\
\text { Infiltration }\end{array}$ & $\begin{array}{c}\text { Mean } \\
\text { Infiltration }\end{array}$ & $\begin{array}{c}\text { High } \\
\text { Infiltration }\end{array}$ \\
\hline 1 & 0.7726 & 0 & 0 \\
\hline 2 & 0.2274 & 0.1522 & 0.0098 \\
\hline 3 & 0 & 0.3345 & 0.1605 \\
\hline 4 & 0 & 0.5133 & 0.5985 \\
\hline 5 & 0 & 0 & 0.2312 \\
\hline Total & 1 & 1 & 1 \\
\hline
\end{tabular}


Analyses for Disposal of Commercial and DOE Waste Inventories at Yucca Mountain - Input to Final Environmental Impact Statement and Site Suitability Evaluation

ATTACHMENT III

GTCC and SPAR INVENTORY 
Analyses for Disposal of Commercial and DOE Waste Inventories at Yucca Mountain - Input to Final Environmental Impact Statement and Site Suitability Evaluation

The following tables were assembled in an EXCEL 97 spreadsheet. The source of the data is DOE 1999 ([DIRS 105155], Volume II, Appendix A, p. A-56 to A-61).

Table III-1 Volume of Inventory and Package Estimate

\begin{tabular}{|c|c|c|}
\hline & Vol (m3) & \# pkgs \\
\hline SPAR & 4000 & 400 \\
\hline GTCC & 2010 & 201 \\
\hline Total & 6010 & 601 \\
\hline \multicolumn{2}{|c|}{ Note: Conversion factor 10 m3/DPC }
\end{tabular}

Table III-2 GTCC Radionuclide Inventory

\begin{tabular}{|c|c|c|c|c|c|c|}
\hline Spec Act. (Ci/g) & GTCC & $\begin{array}{c}\text { Comm } \\
\text { reactor }\end{array}$ & $\begin{array}{c}\text { Sealed } \\
\text { sources }\end{array}$ & Other & Totals (Ci) & Totals (g) \\
\hline $3.44 \mathrm{E}+00$ & Am241 & & $8.00 \mathrm{E}+04$ & $2.40 \mathrm{E}+03$ & $8.24 \mathrm{E}+04$ & $2.40 \mathrm{E}+04$ \\
\hline $2.00 \mathrm{E}-01$ & AM243 & & & & & \\
\hline $4.46 \mathrm{E}+00$ & C14 & $6.80 \mathrm{E}+04$ & & $7.70 \mathrm{E}+03$ & $7.57 \mathrm{E}+04$ & $1.70 \mathrm{E}+04$ \\
\hline $8.65 \mathrm{E}+01$ & CS137 & & $4.00 \mathrm{E}+07$ & $6.60 \mathrm{E}+01$ & $4.00 \mathrm{E}+07$ & $4.62 \mathrm{E}+05$ \\
\hline $1.77 \mathrm{E}-04$ & I129 & & & & $0.00 \mathrm{E}+00$ & $0.00 \mathrm{E}+00$ \\
\hline $7.06 \mathrm{E}-04$ & NP237 & & & & $0.00 \mathrm{E}+00$ & $0.00 \mathrm{E}+00$ \\
\hline $4.72 \mathrm{E}-02$ & PA231 & & & & & \\
\hline $1.71 \mathrm{E}+01$ & PU238 & & $1.60 \mathrm{E}+04$ & & $1.60 \mathrm{E}+04$ & $9.36 \mathrm{E}+02$ \\
\hline $6.22 \mathrm{E}-02$ & PU239 & & $1.07 \mathrm{E}+05$ & & $1.07 \mathrm{E}+05$ & $1.72 \mathrm{E}+06$ \\
\hline $2.28 \mathrm{E}-01$ & PU240 & & & & & \\
\hline $1.03 \mathrm{E}+02$ & PU241 & & & & & \\
\hline $3.82 \mathrm{E}-03$ & PU242 & & & & & \\
\hline $9.90 \mathrm{E}-01$ & RA226 & & & & $0.00 \mathrm{E}+00$ & $0.00 \mathrm{E}+00$ \\
\hline $6.98 \mathrm{E}-02$ & SE79 & & & & & \\
\hline $1.37 \mathrm{E}+02$ & SR90 & & & & $0.00 \mathrm{E}+00$ & $0.00 \mathrm{E}+00$ \\
\hline $1.70 \mathrm{E}-02$ & TC99 & & $5.80 \mathrm{E}+03$ & $5.10 \mathrm{E}-02$ & $5.80 \mathrm{E}+03$ & $3.41 \mathrm{E}+05$ \\
\hline $2.20 \mathrm{E}+01$ & U232 & & & & & \\
\hline $9.69 \mathrm{E}-03$ & U233 & & & & & \\
\hline $6.26 \mathrm{E}-03$ & U234 & & & & & \\
\hline $3.37 \mathrm{E}-07$ & U238 & & $5.70 \mathrm{E}+01$ & & & \\
\hline
\end{tabular}


Analyses for Disposal of Commercial and DOE Waste Inventories at Yucca Mountain - Input to Final Environmental Impact Statement and Site Suitability Evaluation

Table III-3 SPAR Radionuclide Inventory

\begin{tabular}{|c|c|c|c|c|c|c|}
\hline Spec Act (Ci/g) & SPAR & Hanford & INEEL & ORNL & Total Ci & Total (g) \\
\hline $3.44 E+00$ & Am241 & & $2.40 \mathrm{E}+02$ & & $2.40 \mathrm{E}+02$ & $6.98 \mathrm{E}+01$ \\
\hline 2.00E-01 & AM243 & & & & & \\
\hline $4.46 \mathrm{E}+00$ & $\mathrm{C}_{14}$ & & $8.30 \mathrm{E}+02$ & $1.00 \mathrm{E}+01$ & $8.40 E+02$ & $1.88 \mathrm{E}+02$ \\
\hline $8.65 E+01$ & CS137 & $6.00 E+04$ & $3.00 E+01$ & $1.70 E-04$ & $6.00 E+04$ & $6.94 E+02$ \\
\hline 1.77E-04 & 1129 & & & $7.50 \mathrm{E}-05$ & 7.50E-05 & 4.24E-01 \\
\hline 7.06E-04 & NP237 & & & & $0.00 E+00$ & $0.00 E+00$ \\
\hline $1.71 E+01$ & PU238 & & & & $0.00 E+00$ & $0.00 \mathrm{E}+00$ \\
\hline $6.22 \mathrm{E}-02$ & PU239 & & $2.00 \mathrm{E}+01$ & & $2.00 \mathrm{E}+01$ & $3.22 E+02$ \\
\hline $2.28 E-01$ & PU240 & & & & & \\
\hline $1.03 E+02$ & PU241 & & & & & \\
\hline $3.82 E-03$ & PU242 & & & & & \\
\hline $9.90 \mathrm{E}-01$ & RA226 & & $3.00 E+01$ & & $3.00 E+01$ & $3.03 E+01$ \\
\hline 6.98E-02 & SE79 & & & & & \\
\hline 1.37E+02 & SR90 & $6.00 E+04$ & $7.40 E+03$ & & $6.74 E+04$ & $4.92 E+02$ \\
\hline 1.70E-02 & TC99 & & $3.30 E+00$ & 8.00E-01 & $4.10 E+00$ & $2.41 E+02$ \\
\hline $2.20 \mathrm{E}+01$ & U232 & & & & & \\
\hline $9.69 \mathrm{E}-03$ & U233 & & & & & \\
\hline $6.26 \mathrm{E}-03$ & U234 & & & & & \\
\hline 3.37E-07 & U238 & & $5.70 E+01$ & & $5.70 \mathrm{E}+01$ & $1.69 E+08$ \\
\hline
\end{tabular}


Analyses for Disposal of Commercial and DOE Waste Inventories at Yucca Mountain - Input to Final Environmental Impact Statement and Site Suitability Evaluation

Table III-4 Naval SPAR Radionuclide Inventory

\begin{tabular}{|c|c|c|c|c|c|c|c|}
\hline & & Naval (Ci/pkg) & & Naval (Ci/pkg) & & & \\
\hline $\begin{array}{c}\text { Spec Act. } \\
\text { (Ci/g) }\end{array}$ & & small(200) & Ci & large (100) & Ci & Total (Ci) & Total (g) \\
\hline $3.44 E+00$ & AM241 & $5.40 E-02$ & $1.1 E+01$ & $6.00 E-02$ & $6.00 E+00$ & $1.68 E+01$ & $4.88 E+00$ \\
\hline $2.00 E-01$ & AM243 & $5.80 E-04$ & $1.2 E-01$ & $6.50 E-04$ & $6.50 E-02$ & $1.81 E-01$ & $9.05 E-01$ \\
\hline $4.46 E+00$ & C14 & 3.2 & $6.4 E+02$ & 3.6 & $3.60 E+02$ & $1.00 E+03$ & $2.24 E+02$ \\
\hline $8.65 E+01$ & CS137 & 1.1 & $2.2 E+02$ & 1.3 & $1.30 E+02$ & $3.50 E+02$ & $4.05 E+00$ \\
\hline $1.77 E-04$ & I129 & $0.00 E+00$ & $0.0 E+00$ & $0.00 E+00$ & $0.00 E+00$ & $0.00 E+00$ & $0.00 E+00$ \\
\hline $7.06 E-04$ & NP237 & $0.00 E+00$ & $0.0 E+00$ & $0.00 E+00$ & $0.00 E+00$ & $0.00 E+00$ & $0.00 E+00$ \\
\hline $4.72 E-02$ & PA231 & $0.00 E+00$ & $0.0 E+00$ & $0.00 E+00$ & $0.00 E+00$ & $0.00 E+00$ & $0.00 E+00$ \\
\hline $1.71 E+01$ & PU238 & $0.00 E+00$ & $0.0 E+00$ & $0.00 E+00$ & $0.00 E+00$ & $0.00 E+00$ & $0.00 E+00$ \\
\hline $6.22 E-02$ & PU239 & $2.10 E-02$ & $4.2 E+00$ & $2.40 E-02$ & $2.40 E+00$ & $6.60 E+00$ & $1.06 E+02$ \\
\hline $2.28 E-01$ & PU240 & $5.40 E-03$ & $1.1 E+00$ & $6.00 E-03$ & $6.00 E-01$ & $1.68 E+00$ & $7.37 E+00$ \\
\hline $1.03 E+02$ & PU241 & $4.10 E+00$ & $8.2 E+02$ & $4.60 E+00$ & $4.60 E+02$ & $1.28 E+03$ & $1.24 E+01$ \\
\hline $3.82 E-03$ & PU242 & $4.50 E-05$ & $9.0 E-03$ & $5.10 E-05$ & $5.10 E-03$ & $1.41 E-02$ & $3.69 E+00$ \\
\hline $9.90 E-01$ & RA226 & $0.00 E+00$ & $0.0 E+00$ & $0.00 E+00$ & $0.00 E+00$ & $0.00 E+00$ & $0.00 E+00$ \\
\hline $6.98 E-02$ & SE79 & $1.20 E-05$ & $2.4 E-03$ & $1.30 E-05$ & $1.30 E-03$ & $3.70 E-03$ & $5.30 E-02$ \\
\hline $1.37 E+02$ & SR90 & $4.20 E-01$ & $8.4 E+01$ & $4.70 E-01$ & $4.70 E+01$ & $1.31 E+02$ & $9.56 E-01$ \\
\hline $1.70 E-02$ & TC99 & $5.30 E-04$ & $1.1 E-01$ & $6.00 E-04$ & $6.00 E-02$ & $1.66 E-01$ & $9.76 E+00$ \\
\hline $2.20 E+01$ & U232 & $1.20 E-04$ & $2.4 E-02$ & $1.40 E-04$ & $1.40 E-02$ & $3.80 E-02$ & $1.73 E-03$ \\
\hline $9.69 E-03$ & U233 & $7.80 E-05$ & $1.6 E-02$ & $8.80 E-05$ & $8.80 E-03$ & $2.44 E-02$ & $2.52 E+00$ \\
\hline $6.26 E-03$ & U234 & $0.00 E+00$ & $0.0 E+00$ & $0.00 E+00$ & $0.00 E+00$ & $0.00 E+00$ & $0.00 E+00$ \\
\hline $3.37 E-07$ & U238 & $0.00 E+00$ & $0.0 E+00$ & $0.00 E+00$ & $0.00 E+00$ & $0.00 E+00$ & $0.00 E+00$ \\
\hline & & & & & & & \\
\hline
\end{tabular}


Analyses for Disposal of Commercial and DOE Waste Inventories at Yucca Mountain - Input to Final Environmental Impact Statement and Site Suitability Evaluation

Table III-5 Sum of GTCC and SPAR Radionuclide Inventories and Per-Package Inventory Estimate

\begin{tabular}{|c|c|c|}
\hline & SPAR+GTCC & $601 \mathrm{WP}$ \\
\hline & Totals (g) & g per WP \\
\hline Am241 & $2.40 \mathrm{E}+04$ & $4.00 E+01$ \\
\hline AM243 & 9.05E-01 & 1.51E-03 \\
\hline C14 & $1.74 \mathrm{E}+04$ & $2.89 E+01$ \\
\hline CS137 & $4.63 \mathrm{E}+05$ & $7.71 \mathrm{E}+02$ \\
\hline 1129 & $4.24 \mathrm{E}-01$ & $7.05 E-04$ \\
\hline NP237 & $0.00 \mathrm{E}+00$ & $0.00 \mathrm{E}+00$ \\
\hline$\overline{\text { PA231 }}$ & $0.00 \mathrm{E}+00$ & $0.00 \mathrm{E}+00$ \\
\hline PU238 & $9.36 \mathrm{E}+02$ & $1.56 \mathrm{E}+00$ \\
\hline PU239 & $1.72 \mathrm{E}+06$ & $2.86 E+03$ \\
\hline PU240 & $7.37 E+00$ & $1.23 \mathrm{E}-02$ \\
\hline PU241 & $1.24 \mathrm{E}+01$ & $2.07 E-02$ \\
\hline PU242 & $3.69 E+00$ & $6.14 \mathrm{E}-03$ \\
\hline RA226 & $3.03 E+01$ & $5.04 \mathrm{E}-02$ \\
\hline SE79 & $5.30 \mathrm{E}-02$ & 8.82E-05 \\
\hline SR90 & $4.93 \mathrm{E}+02$ & $8.20 E-01$ \\
\hline TC99 & $3.41 E+05$ & $5.68 E+02$ \\
\hline U232 & $1.73 \mathrm{E}-03$ & 2.87E-06 \\
\hline U233 & $2.52 E+00$ & 4.19E-03 \\
\hline U234 & $0.00 E+00$ & $0.00 E+00$ \\
\hline U238 & $3.38 \mathrm{E}+08$ & $5.63 E+05$ \\
\hline
\end{tabular}




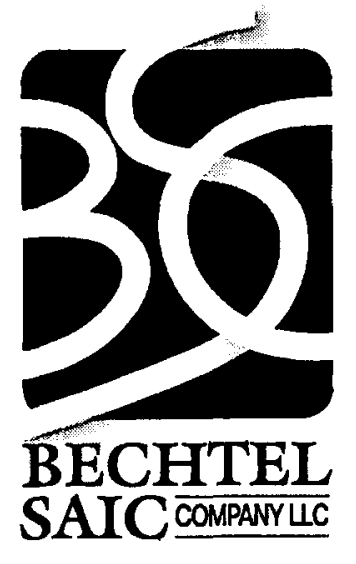

WBS: 1.2 .21

QA:N/A

Enclosure 2

September 17, 2001

\section{Analysis of Post-10,000-Year Features, Events and Processes - Input to Final Environmental Impact Statement}

Prepared for:

U.S. Department of Energy

Yucca Mountain Site CharacterizationOffice

P.O. Box 30307

North Las Vegas, Nevada 89036-0307

Prepared by:

Bechtel SAIC Company, LLC

1180 Town Center Drive

Las Vegas, Nevada 89144

Under Contract Number

DE-AC08-01RW12101 


\section{ANALYSIS OF POST-10,000-YEAR FEATURES, EVENTS AND PROCESSES - INPUT TO FINAL ENVIRONMENTAL IMPACT STATEMENT}

\section{Introduction}

This report provides justification for extension of the following FEPs related to the Yucca Mountain EIS. A screening analysis for the post-10,000-year post-repository-closure time frame is provided below. The following FEPs are considered:

1.2.01.01.00 Tectonic activity

1.2.07.01.00 Erosion/Denudation

1.3.04.00.00 Periglacial effects

1.3.05.00.00 Glacial and ice sheet effects

2.1.07.04.00 Hydrostatic pressure on container

2.3.02.03.00 Soil and Sediment Transport

Screening discussions from the appropriate FEP AMRs were reviewed, and, where applicable, were applied to the post-10,000 year time frame. The post-10,000 year screening decisions presented here are independent from the 10,000 year screening discussions provided in the FEP AMRs. The TSPA FEPs data base that addresses the 10,000-year screening discussion can be found in The Development of Information Catalogued in REV 00 of the YMP FEP Database (Freeze et al., 2001) and in the updates to its supporting documents (particularly BSC 2001a and 2001b, CRMWS M\&O 2000a and 2000b, and CRWMS 2001a). However, the post-10,000 year arguments are specific to the EIS, and will not be added to the FEP AMRs or the FEP Database. This document has a non-Q status.

\subsection{Tectonic activity}

The current strain rate is indicated by Savage et al. (1999, p. 17627) as $<2 \mathrm{~mm} / \mathrm{yr}$ and is reflected in local slip rates of between 0.001 and $0.03 \mathrm{~mm} / \mathrm{yr}$. At the highest rate, the total slip after 10,000 years would be on the order of 0.010 to $0.3 \mathrm{~m}$, but after one million years could be on the order of 1 to $30 \mathrm{~m}$. The increased rates of tectonic and igneous activity in the geologic past (and leading to the $30 \mathrm{~m}$ value) were associated with greater crustal strain rates than exist currently. In particular, Fridrich (1999) indicates extension of the Crater Flat structural basin to have been on the order of 18 to 40 percent between about 12.6 and $11.6 \mathrm{Ma}$ during the major pulse of extension, with the rate of extension declining exponentially since $11.6 \mathrm{Ma}$. During the late Quaternary through the present, the rate of extension is less than $1 \%$ of the initial rate. These studies suggest that crustalextension rates are likely to vary insignificantly or to decrease with time. Consequently, assumption of the existing tectonic setting and strain rates for periods out to 1 million years, for purposes of the EIS, is reasonable, although quantification of associated displacements would exhibit a time-dependent increase in uncertainty. 
The median probability for exceeding fault displacements greater than $3 \mathrm{~m}$ on the Solitario Canyon is approximately $10^{-4}$ in 10,000 years, and the median and mean probability for fault displacement on intrablock faults of $2 \mathrm{~m}$ or greater is less than $10^{-4}$ in 10,000 years (USGS 1998; Wong and Stepp 1998). The projected values assume that the tectonic strain rate is either equal to or less than the existing strain rate. Projection and use of these displacements for a 1 million year time frame is appropriate, but is accompanied with an increase in uncertainty in the probable displacement value.

Based on the repository design, the drifts could accommodate up to $2 \mathrm{~m}$ of vertical displacement on intrablock faults before waste package shearing conditions could occur, and with the use of set-backs, at least $3 \mathrm{~m}$ of offset could be accommodated in the Solitario Canyon, and possibly more if distributed faulting is considered. Hypothetical models at the mountain-scale also suggest that flow in fault zones and fractures would not be significantly impacted by displacement of up to $10 \mathrm{~m}$. The tolerance values are not time dependent. The projected total slip values at one million years $(1$ to $30 \mathrm{~m})$ are of the same order of magnitude as the tolerance limit ( 1 to $10 \mathrm{~m}$ ).

Because the tolerance values are of the same order of magnitude as the projected total slip, and because the tectonic setting and history of the site suggest that strain rates will either vary insignificantly or decrease, the assumptions and models in the TSPA related to tectonic activity should be reasonable and applicable for the one million year time span as well.

\subsection{Erosion/Denudation}

Erosion is a process that is expected to be ongoing at Yucca Mountain. The maximum erosion over a 10,000-year period is expected to be less than $10 \mathrm{~cm}$ (YMP 1993, p. 55), which is within the range of existing surface irregularities. After one million years the maximum total erosion would be 10 meters, assuming the erosion rate estimated for the next 10,000 years remains constant for the next one million years. This maximum value is far less than the amount required to expose waste at the land surface, and possible effects would therefore be limited to changes in infiltration and flow in the unsaturated zone. Local changes of up to 10 meters would represent a small change relative to the hundreds of meters of topographic variability already incorporated in the infiltration model used to calculate flow in the unsaturated zone, and the effects of erosion on infiltration are therefore considered negligible. Erosion due to normal surface processes at Yucca Mountain is therefore excluded from the million-year analyses.

Future climate projections extending to 10,000 years (USGS 2000 and CRWMS 2000c) indicate that, although the climate is expected to evolve to a cooler, wetter climate, conditions will be that of a glacial transition or glacial-type climate. As a result direct glacial erosion and transport is not considered a credible event. Therefore, glacial erosion is excluded on the basis of low probability. 
The effects of erosion processes on how radionuclides may accumulate in soils and subsequently enter the biosphere are included (CRWMS M\&O 2001b; Section 6.1.1) for the post-10,000 year period. The effects of erosional processes in the biosphere are considered in Evaluate Soil/Radionuclide Removal by Erosion and Leaching (CRWMS M\&O 2001b) and are considered in TSPA-SR (CRWMS M\&O 2000d; Sections 3.9 and 3.10 ) as part of the peak dose calculations.

\subsection{Periglacial effects}

This FEP refers to climate conditions that could produce a cold, but glacier-free environment. Results of such a climate could include permafrost (permanently frozen ground). Some consequences of such a condition identified in the secondary FEPs are enhanced erosion due to the freeze/thaw cycle and the trapping of gases in or near the potential repository.

Global climate change is addressed in TSPA using a climate model based on paleoclimate information. That is, the record of climate changes in the past is used to predict the expected changes in climate for the future. Because the geologic record indicates that climatic conditions during the Quaternary period (the past 1.6 million years) at no time resulted in plant communities at Yucca Mountain that are consistent with periglacial conditions (CRWMS M\&O 2000e; Section 4.2.4), the FEP has been excluded on the basis of low probability.

Future climates are described in terms of discrete climate states that are used to approximate continuous variations in climate. The effects of seasonality are included in the climate model through the use of climate analogs with specific seasonal meteorological records. More specific information about the methods used to predict future climate change and the findings for the climate model are given in USGS (2000; Section 6). Climate modeling is incorporated into TSPA through the unsaturated zone flow fields that have different surface water infiltration as a result of different climates. A description of the modeling methods used for infiltration and how infiltration is affected by climate is given in USGS (2000; Section 6).

Potential future climate conditions at Yucca Mountain were analyzed in two model reports (AMRs): Future Climate Analyses (USGS 2000) and Documentation of MillionYear TSPA (CRWMS 2000c). The future climate at Yucca Mountain for the next 10,000 years is treated as a sequence of three climate states: modern (interglacial) climate for 400 to 600 years, monsoon climate for 900 to 1,400 years, and glacial-transition (intermediate) climate for the balance of the 10,000 year period. The glacial-transition climate (intermediate) climate occurs either preceding or following the colder or wetter full glacial climate states. Three additional full-glacial climate states are specified within the longer period of 1,000,000 years, with different climate stages timed with the earth orbital clock. Full-glacial stages encompass about 21 percent of the time over the next $1,000,000$ years. The intermediate climate is the dominant climate for the next $1,000,000$ years. 


\subsection{Glacial and ice sheet effects}

This FEP refers to the local effects of glaciers and ice sheets. Paleoclimate records indicate that glaciers and ice sheets have not occurred at Yucca Mountain at any time in the past (USGS 2000; Section 6.2). The closest alpine glaciers to Yucca Mountain during the Pleistocene were in the Sierra Nevada of California and possibly the Spring Mountains in Nevada (CRWMS M\&O 2000e; Section 4.2.3.3.6), too far from Yucca Mountain to have any effect on site geomorphology or hydrology. Given the relatively low elevation of Yucca Mountain, there is no credible mechanism by which a glacier could form at the site over the next 10,000 years, and there is no evidence to suggest formation of glaciers at Yucca Mountain in the next 1,000,000 years. Therefore, this FEP is excluded on the basis of low probability. Note, however, that the regional climatic effects of ice sheets that might form further north are included based on a change in climate states.

\subsection{Hydrostatic pressure on container}

The design for the potential repository at Yucca Mountain locates waste above the water table in a fractured, porous medium. Thus, the pressure on the waste packages is approximately atmospheric under present conditions. Possible changes in the elevation of the water table due to climate change and tectonic processes have been evaluated (CRWMS M\&O 2001a, Sections 6.2.11 and 6.2.8, BSC 2001a, Section 6.7.6), and water table fluctuations due to climate change are included in the TSPA. Even under the wettest future climate states, however, the highest elevation of the water table will be far below the emplacement drifts, and hydrostatic pressure effects on the packages are therefore excluded from the TSPA on the basis of low probability for both 10,000-year and million-year analyses.

\subsection{Soil and Sediment Transport}

The treatment of soil and sediment transport processes in the million-year analyses is unchanged from the approach taken in the 10,000-year TSPA. Surficial transport processes are included in the development of the biosphere dose conversion factors, and have been considered in the model used for evaluating doses following volcanic eruption. Surficial processes as a mechanism for transporting radionuclides from the repository to the location of the receptor have been excluded from the TSPA on the basis of low consequence.

Transport of soil and sediments in the biosphere are discussed in the AMR entitled Evaluate Soil/Radionuclide Removal by Leaching and Erosion (CRWMS 2001b) and data are presented in the Biosphere Dose Conversion Factors for Nominal Performance (MO0010MWDPBD09.006). The results of these analyses are used in Sections 3.9 and 3.10 of the TSPA-SR (CRWMS M\&O 2000d). Aeolian and fluvial transport of contaminated volcanic ash has been indirectly included in the TSPA-SR igneous disruption scenario through the use of a wind direction fixed toward the critical group for all hypothetical eruptions. As described in Section 3.10 of TSPA-SR (CRWMS M\&O 2000d), use of a fixed wind direction compensates for the lack of an explicit model for 
sediment transport following ash deposition by ensuring that all eruptions result in the deposition of contaminated ash at the location of the critical group, regardless of the wind direction at the time of the event. The TSPA-SR calculations include the probability of eruptive events extending past the 10,000-year regulatory period to calculate peak dose.

Paleoclimate records indicate that glaciers and ice sheets have not occurred at Yucca Mountain at any time in the past (USGS 2000; Section 6.2). The closest alpine glaciers to Yucca Mountain during the Pleistocene were in the Sierra Nevada of California and possibly the Spring Mountains in Nevada (CRWMS M\&O 2000e; Section 4.2.3.3.6), too far from Yucca Mountain to have any effect on site geomorphology or hydrology. Given the relatively low elevation of Yucca Mountain, there is no credible mechanism by which a glacier could form at the site within the time frames considered. Therefore, glacial transport of soil and sediments is not considered credible and this FEP is excluded on the basis of low probability.

\section{REFERENCES CITED}

BSC (Bechtel SAIC Company) 2001a. Features, Events, and Processes in UZ Flow and Transport. ANL-NBS-MD-000001 REV 01. Las Vegas, Nevada: Bechtel SAIC Company. ACC: MOL.20010423.0321. [DIRs 154826]

BSC (Bechtel SAIC Company) 2001b. Evaluation of the Applicability of BiosphereRelated Features, Events, and Processes (FEP). ANL-MGR-MD-000011 REV 01. Las Vegas, Nevada: Bechtel SAIC Company. ACC: MOL.20010226.0003. [DIRs 153921]

Biosphere Dose Conversion Factors for Nominal Performance. Submittal date: 10/05/2000. MO0010MWDPBD09.006. [DIRs 152887]

CRWMS M\&O 2000a. Features, Events, and Processes: Disruptive Events. ANL-WISMD-000005 REV 00 ICN 1. Las Vegas, Nevada: CRWMS M\&O. ACC: MOL.20001218.0007. [DIRs 151553]

CRWMS M\&O 2000b. Engineered Barrier System Features, Events, and Processes, and Degradation Modes Analysis. ANL-EBS-MD-000035 REV 00 ICN 01. Las Vegas, Nevada: CRWMS M\&O. ACC: MOL.20000727.0092. [DIRs 150825]

CRWMS M\&O 2000c. Documentation of Million-Year TSPA. Input Transmittal 00393.T. Las Vegas, Nevada: CRWMS M\&O. ACC: MOL.20001110.0057; MOL.20001120.0173.

CRWMS M\&O 2000d. Total System Performance Assessment for the Site Recommendation. TDR-WIS-PA-000001 REV 00 ICN 01. Las Vegas, Nevada: CRWMS M\&O. ACC: MOL.20001220.0045. [DIRs 153246] 
CRWMS M\&O 2000e. Yucca Mountain Site Description. TDR-CRW-GS-000001 REV 01 ICN 01. Las Vegas, Nevada: CRWMS M\&O. ACC: MOL.20001003.0111. . [DIRs 151945]

CRWMS M\&O 2001a. Features, Events, and Processes in SZ Flow and Transport. ANL-NBS-MD-000002 REV 01. Las Vegas, Nevada: CRWMS M\&O. ACC:

MOL.20010214.0230. [DIRs 153931]

CRWMS M\&O 2001b. Evaluate Soil/Radionuclide Removal by Erosion and Leaching. ANL-NBS-MD-000009 REV 00 ICN 01. Las Vegas, Nevada: CRWMS M\&O. ACC: MOL.20010214.0032. DIRs [152517]

Freeze, G.A.; Brodsky, N.S.; and Swift, P.N. 2001. The Development of Information Catalogued in REV 00 of the YMP FEP Database. TDR-WIS-MD-000003 REV 00 ICN 01. Las Vegas, Nevada: Bechtel SAIC Company. ACC: MOL.20010301.0237. [DIRs 154365]

Fridrich, C.J. 1999. "Tectonic Evolution of the Crater Flat Basin, Yucca Mountain Region, Nevada." Chapter 7 of Cenozoic Basins of the Death Valley Region. Wright, L.A. and Troxel, B.W., eds. Special Paper 333. Boulder, Colorado: Geological Society of America. TIC: 248054. [DIRs 118942]

Savage, J.C.; Svarc, J.L.; and Prescott, W.H. 1999. "Strain Accumulation at Yucca Mountain, Nevada, 1983-1998." Journal of Geophysical Research, 104, (B8), 1762717631. Washington, D.C.: American Geophysical Union. TIC: 245645. [DIRs 118952]

USGS (U.S. Geological Survey) 1998. Probabilistic Seismic Hazard Analyses for Fault Displacement and Vibratory Ground Motion at Yucca Mountain, Nevada. Milestone SP32IM3, June 15, 1998. Three volumes. Oakland, California: U.S. Geological Survey. ACC: MOL.19980619.0640. [DIRs 100354]

USGS (U.S. Geological Survey) 2000. Future Climate Analysis. ANL-NBS-GS-000008 REV 00. Denver, Colorado: U.S. Geological Survey. ACC: MOL.20000629.0907. [DIRs 136368]

Wong, I.G. and Stepp, C. 1998. Probabilistic Seismic Hazard Analyses for Fault Displacement and Vibratory Ground Motion at Yucca Mountain, Nevada. Milestone SP32IM3, September 23, 1998. Three volumes. Oakland, California: U.S. Geological Survey. ACC: MOL.19981207.0393. [DIRs 103731]

YMP (Yucca Mountain Site Characterization Project) 1993. Evaluation of the Potentially Adverse Condition "Evidence of Extreme Erosion During the Quaternary Period" at Yucca Mountain, Nevada. Topical Report YMP/92-41-TPR. Las Vegas, Nevada: Yucca Mountain Site Characterization Office. ACC: NNA.19930316.0208 [DIRs 100520] 


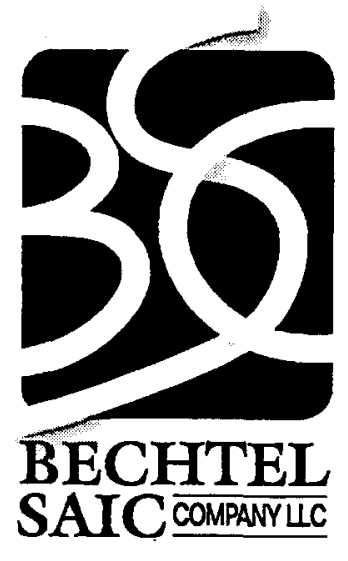

WBS: 1.2.21

QA:N/A

Enclosure 3

September 17, 2001

\section{Analysis of Plume Spreading Caused by Dispersion}

Prepared for:

U.S. Department of Energy

Yucca Mountain Site CharacterizationOffice

P.O. Box 30307

North Las Vegas, Nevada 89036-0307

Prepared by:

Bechtel SAIC Company, LLC

1180 Town Center Drive

Las Vegas, Nevada 89144

Under Contract Number

DE-AC08-01RW12101 


\section{ANALYSIS OF PLUME SPREADING CAUSED BY DISPERSION}

\section{PURPOSE}

The purpose of this transmittal is to provide cursory documentation of the sensitivity analyses completed on plume spreading caused by dispersion. The plume starts at the potential repository site and moves downstream with the groundwater in the saturated zone to the $18-\mathrm{km}, 30-\mathrm{km}$, and $60-\mathrm{km}$ boundary points. The analysis identifies the trends to plume size and peak concentration caused by dispersion as the plume travels in the alluvium from the $18-\mathrm{km}$ to the $30-\mathrm{km}$ point and from the $30-\mathrm{km}$ to the $60-\mathrm{km}$ point.

\section{METHODS}

The spreading of the plume was simulated using the code 3DADE. This code, which was developed by the U.S. Department of Agriculture, evaluates analytical solutions to the onedimensional advection, three-dimensional (3-D) dispersion equation for describing relatively simple scenarios.

\section{INPUTS}

In these calculations, the groundwater flow velocity in the alluvium is assumed to be horizontal with a constant value of 18 meters per year $(\mathrm{m} / \mathrm{y})$, corresponding to a specific discharge rate of $2.7 \mathrm{~m} / \mathrm{y}$ and an effective porosity of $15 \%$ throughout the flow domain. These values are derived from the saturated zone site-scale model as documented in Supplementary Science and Performance Assessment, Volume 1, Section 12. Calculations are done under steady-state conditions, that is, for a source that has been discharging for a long time. The source is assumed to be of constant concentration, located within a rectangular area in the vertical plane, and centered at the potential repository location. Two source sizes are considered: a small source, $10 \mathrm{~m}$ by $10 \mathrm{~m}$, corresponding to an early failure scenario (i.e, localized failing waste package), and a large source, $3000 \mathrm{~m}$ (horizontal) by $10 \mathrm{~m}$ (vertical), corresponding to a long-term scenario in which all waste packages have failed. The top of the source coincides with the water table. The water table is simulated as a no-flux boundary for solute transport and is accounted for by using a double-source thickness in the vertical direction.

Two sets of values for dispersivities are considered:

\section{Case I: High Values}

Longitudinal dispersivity $\left(A_{1}\right)=100 \mathrm{~m}$

Transverse dispersivity, horizontal $\left(A_{t h}\right)=10 \mathrm{~m}$

Transverse dispersivity, vertical $\left(A_{t v}\right)=0.1 \mathrm{~m}$

Case II: Low Values

Longitudinal dispersivity $\left(A_{1}\right)=100 \mathrm{~m}$

Transverse dispersivity, horizontal $\left(A_{t h}\right)=0.5 \mathrm{~m}$

Transverse dispersivity, vertical $\left(A_{t v}\right)=0.005 \mathrm{~m}$ 
Case I dispersivity values are based on literature values for similar aquifer material and the relationship between horizontal transverse and longitudinal values offered by Shlomo Neuman as part of the Saturated Zone Expert Elicitation panel (CRWMS M\&O, 1998). The vertical transverse is 10 percent of the horizontal.

Case II dispersivity values are conservative values used in the Total System Performance Assessment for Site Recommendation. Lynn Gelhar offered the relationship between transverse and longitudinal values as part of the Saturated Zone Expert Elicitation panel (CRWMS M\&O 1998).

\section{RESULTS}

Outputs from the model are manipulated to yield a plume cross section (relative concentration curves as a function of both horizontal ( $y$ ) and vertical ( $\mathrm{z}$ ) space). Both the $\mathrm{y}$ and $\mathrm{z}$ directions are perpendicular to the flow direction. Figures 1 through 6 are examples of the relative concentration curves, which consist of the variation of relative plume concentration with space depth and width. The resulting plume cross sections are integrated to estimate the crosssectional area, capturing $90 \%$ and $99 \%$ of the mass at three distances downstream: $18 \mathrm{~km}, 30$ $\mathrm{km}$, and $60 \mathrm{~km}$. These values are reported in Tables $1 \mathrm{a}$ and $1 \mathrm{~b}$ along with the peak value of the relative concentration.

The plume concentrations are calculated and output is given from 3DADE at discrete points along a vertical line and along a horizontal line through the center. In most cases, a spacing of $5 \mathrm{~m}$ along the horizontal and $0.1 \mathrm{~m}$ along the vertical is used. A simple FORTRAN code, called plum2.f, was developed to post-process the outputs of 3DADE for determining the discharge areas for $90 \%$ and $99 \%$ mass fraction of the plume. The code finds the location of the peak of the plume and the distance at which the concentration drops to 0 . This range is divided into 200 intervals. Each interval is numerically integrated using linear interpolation between grid points. The distances from the center at which the concentration drops to $90 \%$ and $99 \%$ of the total integral are calculated. The procedure is repeated in the horizontal and the vertical directions. The values in the horizontal direction are the half-widths of the plume, whereas those in the vertical represent the full width since a water-table condition is simulated at the center of the plume.

To identify trends in plume spreading and attenuation of peak concentration, ratios of plume sizes and peak concentrations are calculated for plume travel from $18 \mathrm{~km}$ to $30 \mathrm{~km}$ and from $30 \mathrm{~km}$ to $60 \mathrm{~km}$. The ratios are the volume containing $90 \%$ or $99 \%$ of the plume at $30 \mathrm{~km}$ divided by that at $18 \mathrm{~km}$ and the ratio of peak concentration at $30 \mathrm{~km}$ divided by that at $18 \mathrm{~km}$. The ratios for the $60 \mathrm{~km}$ to $30 \mathrm{~km}$ are calculated in a similar fashion. These results are tabulated in Tables $2 a$ and $2 b$.

It is important to note that the results indicate that the ratio of the flow cross sections containing the plume and the peak concentration attenuation are similar for both dispersivity cases. 


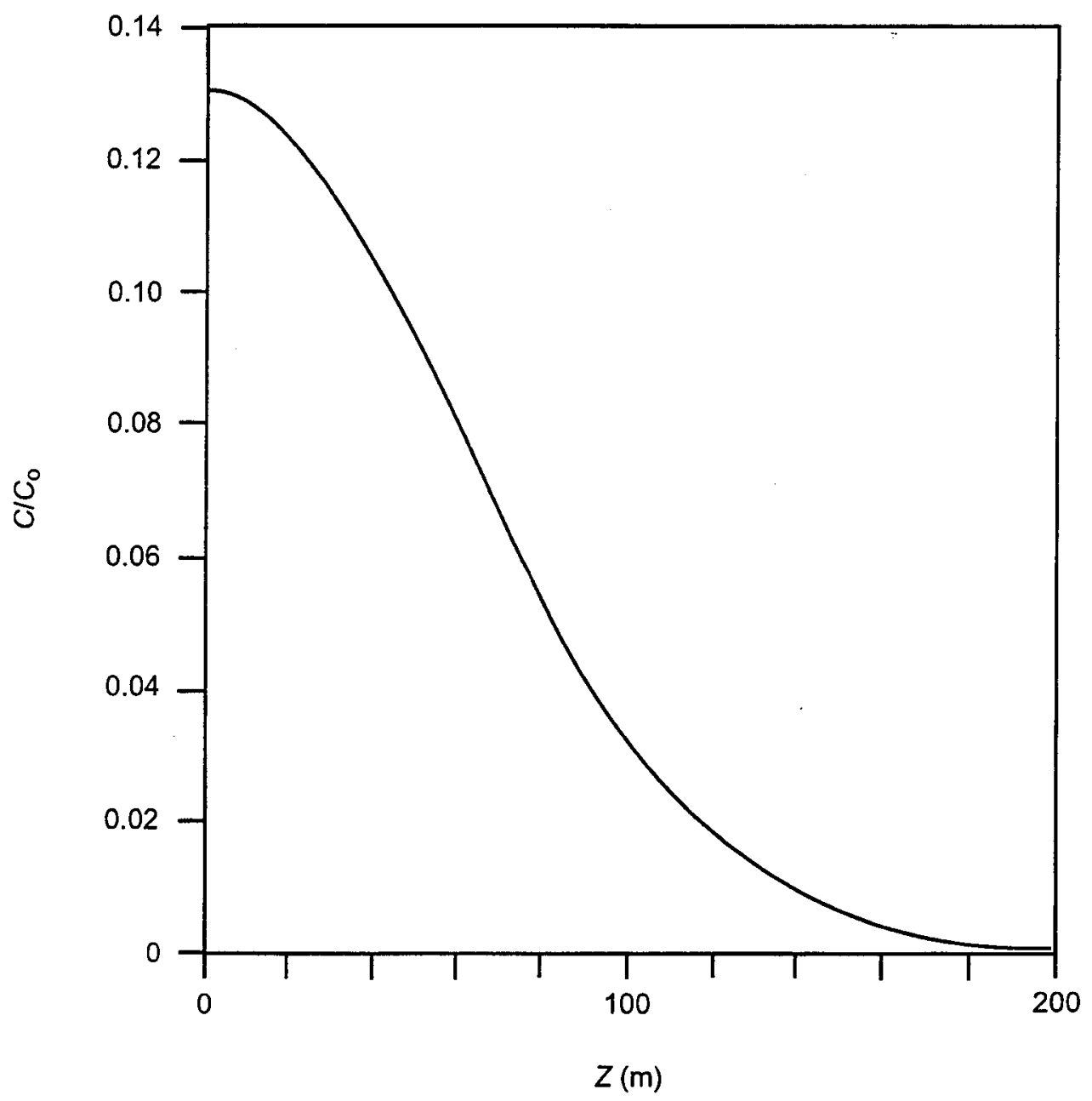

Figure 1. Concentration Profile, Vertical Section at $18 \mathrm{~km}$, Source Dimensions $3000 \mathrm{~m} \times 10 \mathrm{~m}$, $A_{1}=100 \mathrm{~m}, A_{\mathrm{th}}=10 \mathrm{~m}, A_{\mathrm{tv}}=0.1 \mathrm{~m}$. 


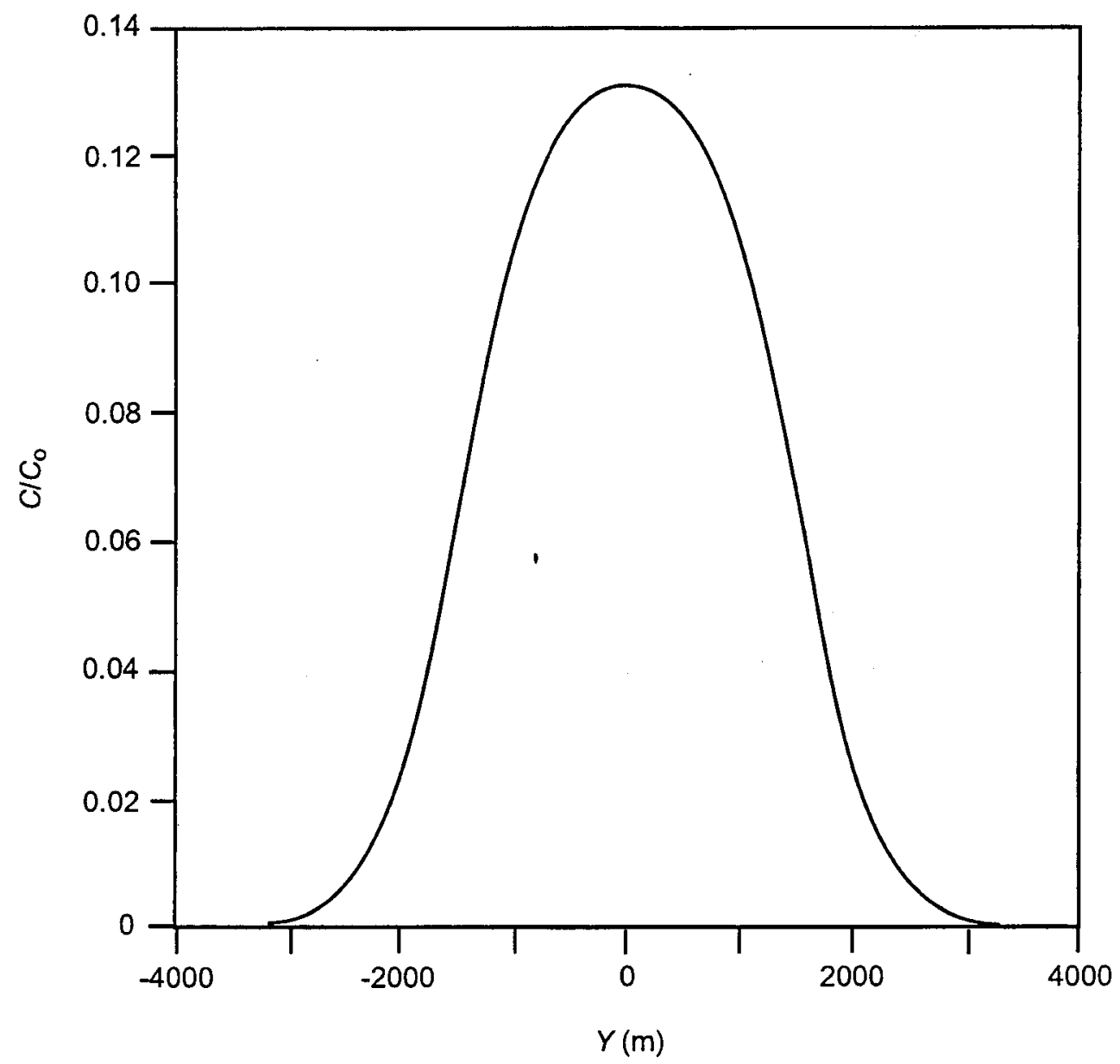

Figure 2. Concentration Profile, Horizontal Section at $18 \mathrm{~km}$, Source Dimensions $3000 \mathrm{~m} \times 10 \mathrm{~m}$, $A_{\mathrm{l}}=100 \mathrm{~m}, A_{\mathrm{th}}=10 \mathrm{~m}, A_{\mathrm{tv}}=0.1 \mathrm{~m}$. 


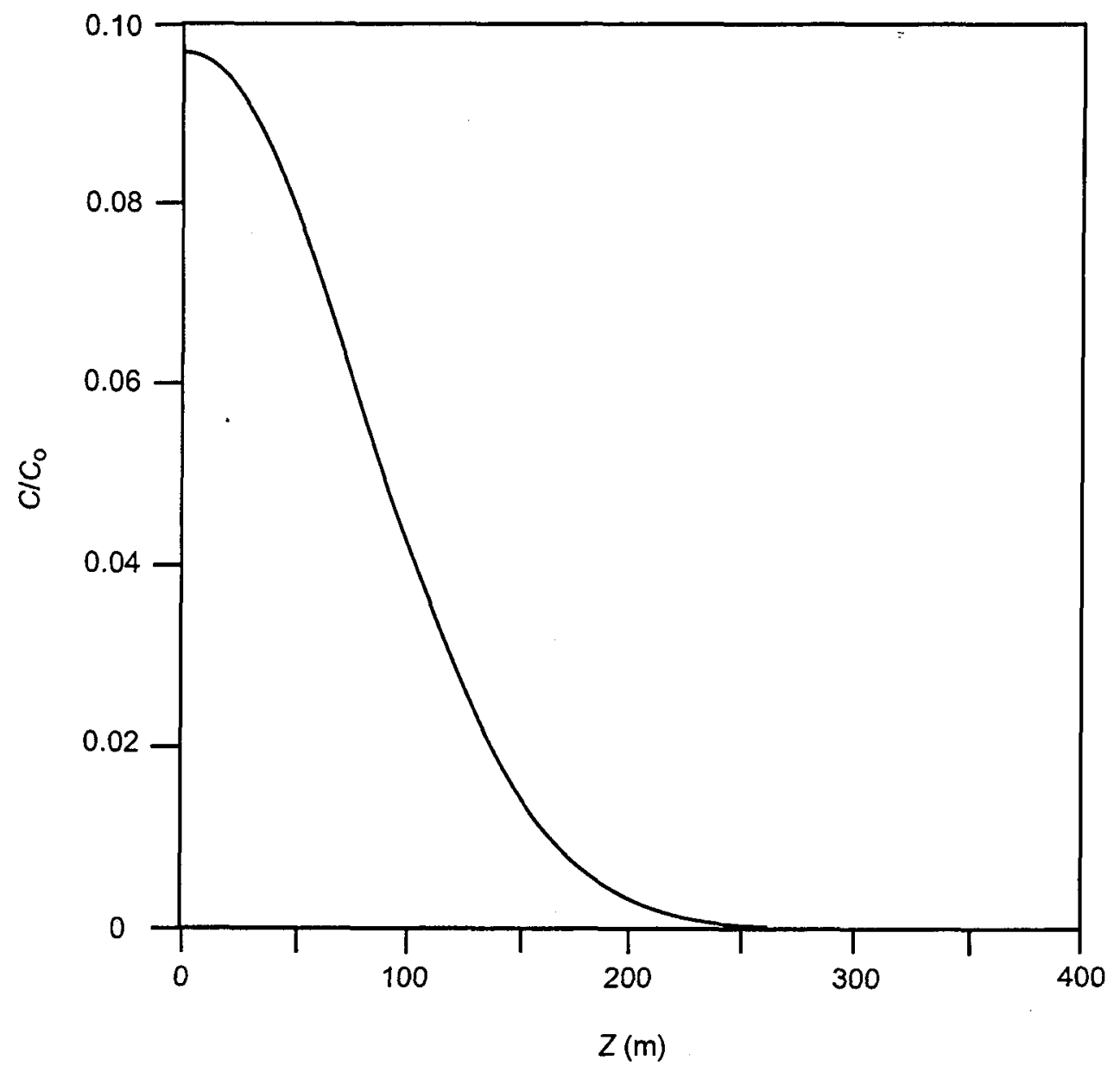

Figure 3. Concentration Profile, Vertical Section at $30 \mathrm{~km}$, Source Dimensions $3000 \mathrm{~m} \times 10 \mathrm{~m}$, $A_{\mathrm{l}}=100 \mathrm{~m}, A_{\mathrm{th}}=10 \mathrm{~m}, A_{\mathrm{tv}}=0.1 \mathrm{~m}$. 


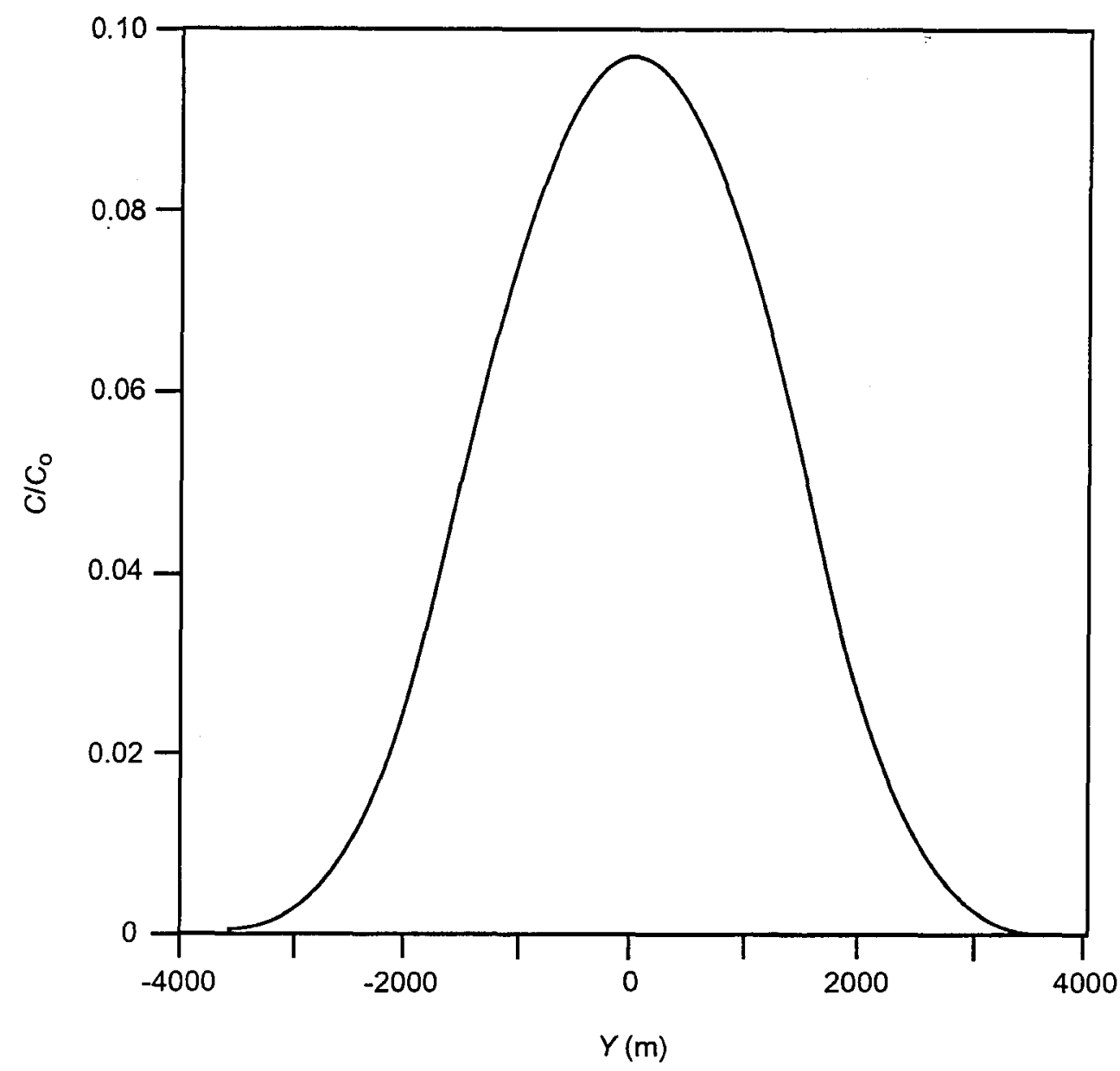

Figure 4. Concentration Profile, Horizontal Section at $30 \mathrm{~km}$, Source Dimensions $3000 \mathrm{~m} \times 10 \mathrm{~m}$, $A_{1}=100 \mathrm{~m}, A_{\mathrm{th}}=10 \mathrm{~m}, A_{\mathrm{tv}}=0.1 \mathrm{~m}$. 


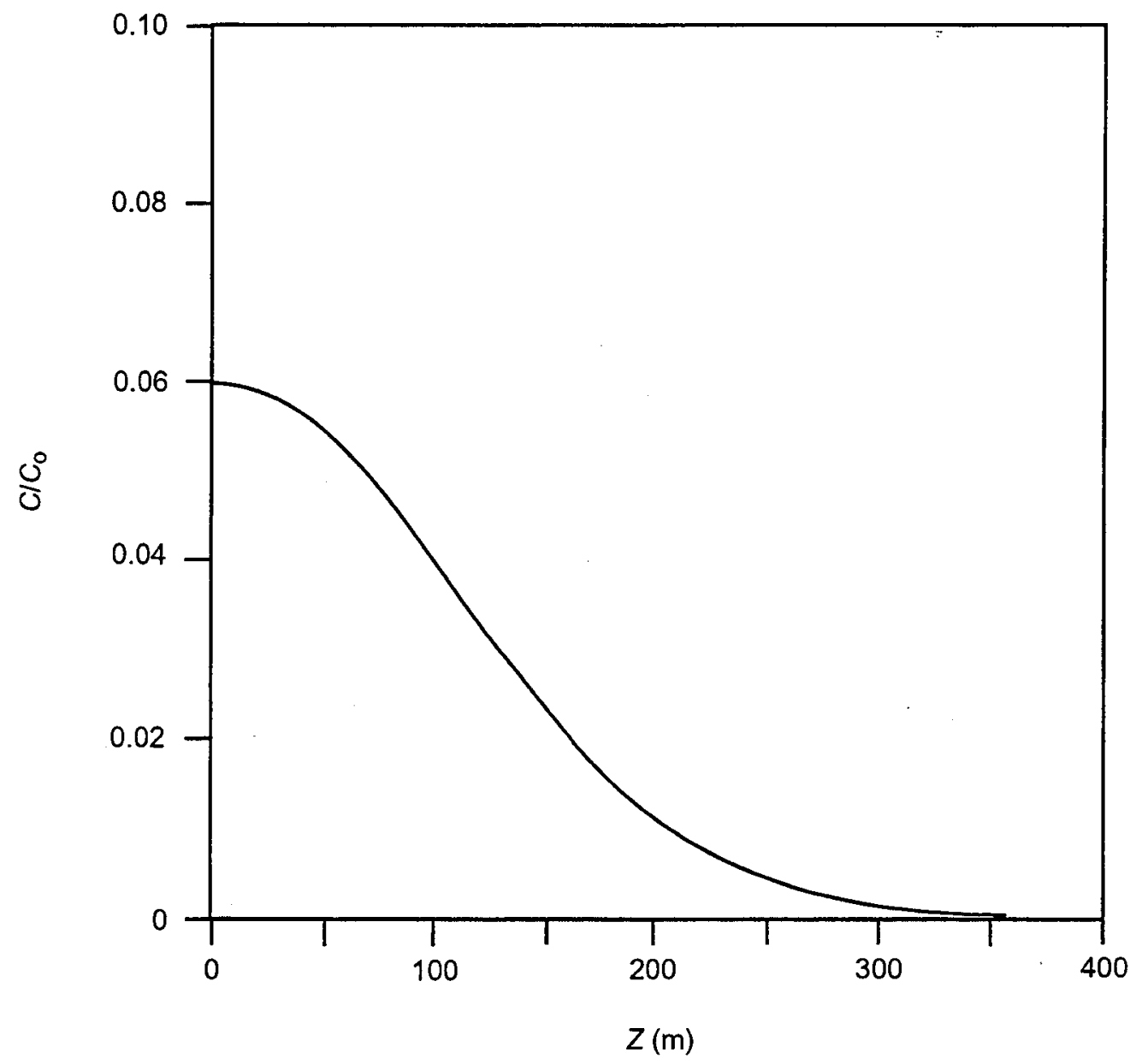

Figure 5. Concentration Profile, Vertical Section at $60 \mathrm{~km}$, Source Dimensions $3000 \mathrm{~m} \times 10 \mathrm{~m}$, $A_{\mathrm{l}}=100 \mathrm{~m}, A_{\mathrm{th}}=10 \mathrm{~m}, A_{\mathrm{tv}}=0.1 \mathrm{~m}$. 


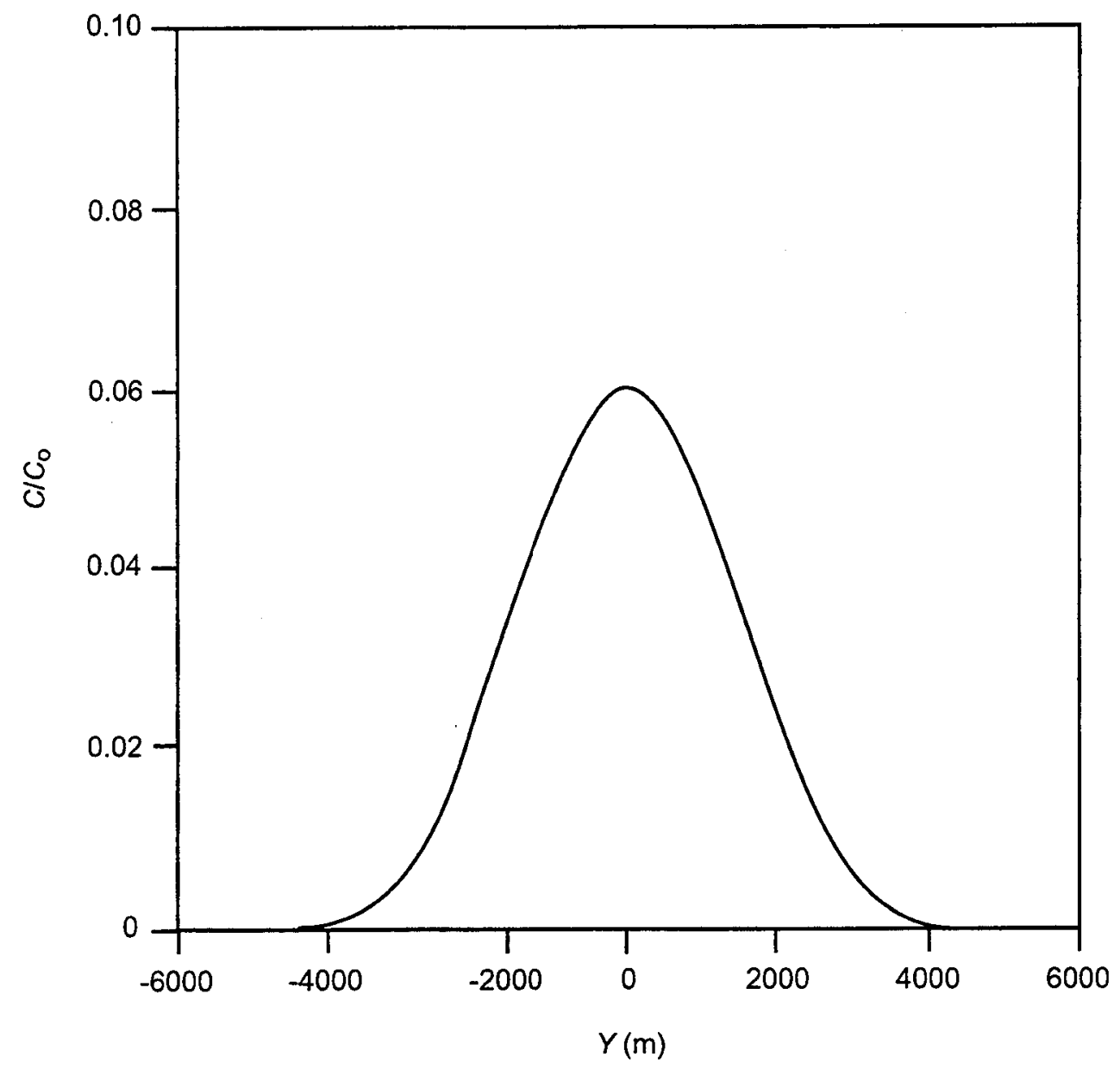

Figure 6. Concentration Profile, Horizontal Section at $60 \mathrm{~km}$, Source Dimensions $3000 \mathrm{~m} \times 10 \mathrm{~m}$, $A_{1}=100 \mathrm{~m}, A_{\mathrm{th}}=10 \mathrm{~m}, A_{\mathrm{tv}}=0.1 \mathrm{~m}$. 
Table 1a. Discharge Areas and Peak Concentrations of Plume Cross Sections for $99 \%$ Captured Mass

\begin{tabular}{|c|c|c|c|}
\hline \multirow[t]{2}{*}{ Case } & \multicolumn{3}{|c|}{$\begin{array}{l}\text { Discharge Area }\left(\mathrm{m}^{2}\right) \text { for } 99 \% \text { Captured Mass } \\
\left.\text { and \{Peak Relative Concentration }\left(C / C_{0}\right)\right\}\end{array}$} \\
\hline & $18 \mathrm{~km}$ & $30 \mathrm{~km}$ & $60 \mathrm{~km}$ \\
\hline 1. Large Source: $3000 \mathrm{~m} \times 10 \mathrm{~m}$ & $7.6 \times 10^{5}$ & $1.1 \times 10^{6}$ & $2.0 \times 10^{6}$ \\
\hline$A_{\mathrm{l}}=100 \mathrm{~m}, A_{\mathrm{th}}=10 \mathrm{~m}, A_{\mathrm{tv}}=0.1 \mathrm{~m}$ & $\left\{1.3 \times 10^{-1}\right\}$ & $\left\{9.8 \times 10^{-2}\right\}$ & $\left\{6.0 \times 10^{-2}\right\}$ \\
\hline 2. Large Source: $3000 \mathrm{~m} \times 10 \mathrm{~m}$ & $1.3 \times 10^{5}$ & $1.6 \times 10^{5}$ & $2.3 \times 10^{5}$ \\
\hline$A_{1}=100 \mathrm{~m}, A_{\mathrm{th}}=0.5 \mathrm{~m}, A_{\mathrm{tv}}=0.005 \mathrm{~m}$ & $\left\{5.5 \times 10^{-1}\right\}$ & $\left\{4.4 \times 10^{-1}\right\}$ & $\left\{3.2 \times 10^{-1}\right\}$ \\
\hline 3. Small Source: $10 \mathrm{~m} \times 10 \mathrm{~m}$ & $3.8 \times 10^{5}$ & $5.3 \times 10^{5}$ & $7.7 \times 10^{5}$ \\
\hline$A_{\mathrm{l}}=100 \mathrm{~m}, A_{\mathrm{th}}=10 \mathrm{~m}, A_{\mathrm{tv}}=0.1 \mathrm{~m}$ & $\left\{9.0 \times 10^{-4}\right\}$ & $\left\{5.0 \times 10^{-4}\right\}$ & $\left\{3.0 \times 10^{-4}\right\}$ \\
\hline 4. Small Source: $10 \mathrm{~m} \times 10 \mathrm{~m}$ & $2.6 \times 10^{4}$ & $4.1 \times 10^{4}$ & $7.9 \times 10^{4}$ \\
\hline$A_{\mathrm{l}}=100 \mathrm{~m}, A_{\mathrm{th}}=0.5 \mathrm{~m}, A_{\mathrm{tv}}=0.005 \mathrm{~m}$ & $\left\{1.6 \times 10^{-2}\right\}$ & $\left\{1.0 \times 10^{-2}\right\}$ & $\left\{5.0 \times 10^{-3}\right\}$ \\
\hline
\end{tabular}

Table 1b. Discharge Areas and Peak Concentrations of Plume Cross Sections for $90 \%$ Captured Mass

\begin{tabular}{|c|c|c|c|}
\hline \multirow[t]{2}{*}{ Case } & \multicolumn{3}{|c|}{$\begin{array}{c}\text { Discharge Area }\left(\mathrm{m}^{2}\right) \text { for } \sim 90 \% \text { Captured Mass } \\
\text { and }\left\{\text { Peak Relative Concentration }\left(C / C_{0}\right)\right\}\end{array}$} \\
\hline & $18 \mathrm{~km}$ & $30 \mathrm{~km}$ & $60 \mathrm{~km}$ \\
\hline 1. Large Source: $3000 \mathrm{~m} \times 10 \mathrm{~m}$ & $3.4 \times 10^{5}$ & $4.8 \times 10^{5}$ & $8.3 \times 10^{5}$ \\
\hline$A_{l}=100 \mathrm{~m}, A_{\mathrm{th}}=10 \mathrm{~m}, A_{\mathrm{tv}}=0.1 \mathrm{~m}$ & $\left\{1.3 \times 10^{-1}\right\}$ & $\left\{9.8 \times 10^{-2}\right\}$ & $\left\{6.0 \times 10^{-2}\right\}$ \\
\hline 2. Large Source: $3000 \mathrm{~m} \times 10 \mathrm{~m}$ & $6.5 \times 10^{4}$ & $8.2 \times 10^{4}$ & $1.2 \times 10^{5}$ \\
\hline$A_{\mathrm{l}}=100 \mathrm{~m}, A_{\mathrm{th}}=0.5 \mathrm{~m}, A_{\mathrm{tv}}=0.005 \mathrm{~m}$ & $\left\{5.5 \times 10^{-1}\right\}$ & $\left\{4.4 \times 10^{-1}\right\}$ & $\left\{3.2 \times 10^{-1}\right\}$ \\
\hline 3. Small Source: $10 \mathrm{~m} \times 10 \mathrm{~m}$ & $1.9 \times 10^{5}$ & $2.9 \times 10^{5}$ & $5.4 \times 10^{5}$ \\
\hline$A_{1}=100 \mathrm{~m}, A_{\mathrm{th}}=10 \mathrm{~m}, A_{\mathrm{tv}}=0.1 \mathrm{~m}$ & $\left\{9.0 \times 10^{-4}\right\}$ & $\left\{5.0 \times 10^{-4}\right\}$ & $\left\{3.0 \times 10^{-4}\right\}$ \\
\hline 4. Small Source: $10 \mathrm{~m} \times 10 \mathrm{~m}$ & $1.1 \times 10^{4}$ & $1.7 \times 10^{4}$ & $3.3 \times 10^{4}$ \\
\hline$A_{\mathrm{l}}=100 \mathrm{~m}, A_{\mathrm{th}}=0.5 \mathrm{~m}, A_{\mathrm{tv}}=0.005 \mathrm{~m}$ & $\left\{1.6 \times 10^{-2}\right\}$ & $\left\{1.0 \times 10^{-2}\right\}$ & $\left\{5.0 \times 10^{-3}\right\}$ \\
\hline
\end{tabular}


Table 2a. Ratio of Discharge Areas and Peak Concentrations of Plume Cross Sections for $99 \%$ Captured Mass

\begin{tabular}{|c|c|c|}
\hline \multirow[t]{2}{*}{ Case } & \multicolumn{2}{|c|}{$\begin{array}{l}\text { Ratio of Discharge Area for } 99 \% \text { Captured Mass } \\
\text { Ratio of }\left\{\text { Peak Relative Concentration } \mathrm{C} / C_{0}\right\}\end{array}$} \\
\hline & $18 \mathrm{~km}$ to $30 \mathrm{~km}$ & $30 \mathrm{~km}$ to $60 \mathrm{~km}$ \\
\hline 1. Large Source: $3000 \mathrm{~m} \times 10 \mathrm{~m}$ & $6.8 \times 10^{-1}(1.5)$ & $5.7 \times 10^{-1}(1.8)$ \\
\hline$A_{\mathrm{l}}=100 \mathrm{~m}, A_{\mathrm{th}}=10 \mathrm{~m}, A_{\mathrm{tv}}=0.1 \mathrm{~m}$ & $\left\{7.4 \times 10^{-1}(1.3)\right\}$ & $\left\{6.2 \times 10^{-1}(1.6)\right\}$ \\
\hline 2. Large Source: $3000 \mathrm{~m} \times 10 \mathrm{~m}$ & $7.7 \times 10^{-1}(1.3)$ & $6.8 \times 10^{-1}(1.5)$ \\
\hline$A_{1}=100 \mathrm{~m}, A_{\mathrm{th}}=0.5 \mathrm{~m}, A_{\mathrm{tv}}=0.005 \mathrm{~m}$ & $\left\{8.0 \times 10^{-1}(1.2)\right\}$ & $\left\{7.2 \times 10^{-1}(1.4)\right\}$ \\
\hline 3. Small Source: $10 \mathrm{~m} \times 10 \mathrm{~m}$ & $7.0 \times 10^{-1}(1.4)$ & $6.9 \times 10^{-1}(1.4)$ \\
\hline$A_{1}=100 \mathrm{~m}, A_{\text {th }}=10 \mathrm{~m}, A_{\mathrm{tv}}=0.1 \mathrm{~m}$ & $6.7 \times 10^{-1}(1.6)$ & $\left\{5.0 \times 10^{-1}(2.0)\right\}$ \\
\hline 4. Small Source: $10 \mathrm{~m} \times 10 \mathrm{~m}$ & $6.2 \times 10^{-1}(1.6)$ & $5.3 \times 10^{-1}(1.9)$ \\
\hline$A_{\mathrm{l}}=100 \mathrm{~m}, A_{\mathrm{th}}=0.5 \mathrm{~m}, A_{\mathrm{tv}}=0.005 \mathrm{~m}$ & $\left\{6.2 \times 10^{-1}(1.6)\right\}$ & $\left\{5.0 \times 10^{-1}(2.0)\right\}$ \\
\hline
\end{tabular}

Table 2b. Ratio of Discharge Areas and Peak Concentrations of Plume Cross Sections for $90 \%$ Captured Mass

\begin{tabular}{|c|c|c|}
\hline \multirow[t]{2}{*}{ Case } & \multicolumn{2}{|c|}{$\begin{array}{l}\text { Ratio of Discharge Area for } 90 \% \text { Captured Mass } \\
\text { Ratio of }\left\{\text { Peak Relative Concentration } \mathrm{C} / \mathrm{C}_{\mathrm{o}}\right\}\end{array}$} \\
\hline & $18 \mathrm{~km}$ to $30 \mathrm{~km}$ & $30 \mathrm{~km}$ to $60 \mathrm{~km}$ \\
\hline 1. Large Source: $3000 \mathrm{~m} \times 10 \mathrm{~m}$ & $7.0 \times 10^{-1}(1.4)$ & $5.9 \times 10^{-1}(1.7)$ \\
\hline$A_{1}=100 \mathrm{~m}, A_{\mathrm{th}}=10 \mathrm{~m}, A_{\mathrm{tv}}=0.1 \mathrm{~m}$ & $\left\{7.4 \times 10^{-1}(1.3)\right\}$ & $\left\{6.2 \times 10^{-1}(1.6)\right\}$ \\
\hline 2. Large Source: $3000 \mathrm{~m} \times 10 \mathrm{~m}$ & $7.9 \times 10^{-1}(1.3)$ & $7.1 \times 10^{-1}(1.4)$ \\
\hline$A_{1}=100 \mathrm{~m}, A_{t h}=0.5 \mathrm{~m}, A_{t y}=0.005 \mathrm{~m}$ & $\left\{8.0 \times 10^{-1}(1.2)\right\}$ & $\left\{7.2 \times 10^{-1}(1.4)\right\}$ \\
\hline 3. Small Source: $10 \mathrm{~m} \times 10 \mathrm{~m}$ & $6.2 \times 10^{-1}(1.6)$ & $5.4 \times 10^{-1}(1.8)$ \\
\hline$A_{\mathrm{l}}=100 \mathrm{~m}, A_{\mathrm{th}}=10 \mathrm{~m}, A_{\mathrm{tv}}=0.1 \mathrm{~m}$ & $\left\{5.6 \times 10^{-1}(1.8)\right\}$ & $\left\{6.0 \times 10^{-1}(1.7)\right\}$ \\
\hline 4. Small Source: $10 \mathrm{~m} \times 10 \mathrm{~m}$ & $6.1 \times 10^{-1}(1.6)$ & $5.2 \times 10^{-1}(1.9)$ \\
\hline$A_{\mathrm{l}}=100 \mathrm{~m}, A_{\mathrm{th}}=0.5 \mathrm{~m}, A_{\mathrm{tv}}=0.005 \mathrm{~m}$ & $\left\{6.3 \times 10^{-1}(1.6)\right\}$ & $\left\{5.0 \times 10^{-1}(2.0)\right\}$ \\
\hline
\end{tabular}




\section{ATTACHMENT I}

\section{SOFTWARE ROUTINE 3DADE}

\section{Routine: 3DADE Version number: REV 00}

\section{SOFTWARE ROUTINE DENTIFICATION}

The 3DADE code was developed under industry standard software FORTRAN 77 . This software routine is used to verify the particle-tracking methodology described in Analysis and Model report MDL-NBS-HS-000010 REV 00, Saturated Zone Transport Methodology and Transport Component Integration.

\section{DESCRIPTION AND TESTING}

\section{a) Description and Equations of Mathematical Models}

This software routine solves the advection-dispersion equation in three dimensions and uses constant concentration (or first-type) boundary conditions at the inlet location of the medium as described by Leij et al (1991, p. 2720)

$$
R \frac{\partial C}{\partial t}=D_{x} \frac{\partial^{2} C}{\partial x^{2}}-v \frac{\partial C}{\partial x}+D_{y} \frac{\partial^{2} C}{\partial y^{2}}+D_{z} \frac{\partial^{2} C}{\partial z^{2}}-\mu C+\lambda \quad t>0,0<x<\infty,-\infty<y<\infty,-\infty<z<\infty
$$

where

$R$ is the retardation factor

$C$ is the volume averaged or resident concentration of the solute $\left(\mathrm{ML}^{-3}\right)$

$t$ is the time (T)

$x$ is the position (L) in the direction of flow

$y$ and $z$ are rectangular coordinates, all perpendicular to the flow direction (L)

$D_{x}, D_{y}$, and $D_{z}$ are dispersion coefficients $\left(\mathrm{L}^{2} \mathrm{t}^{-1}\right)$ in the $x, y$, and $z$ directions, respectively

$v$ is the pore-water velocity $\left(\mathrm{LT}^{-1}\right)$

$\mu$ is a general, first-order, rate coefficient for decay $\left(\mathrm{T}^{-1}\right)$

$\lambda$ is a general, zero-order, rate coefficient for production $\left(\mathrm{ML}^{-3} \mathrm{~T}^{-1}\right)$.

The software routine 3DADE has various geometric source-term scenarios for which it solves Equation I-1. This software routine will only encompass one scenario of 3DADE. The general geometry and source location used for the analyses described herein is shown in Figure I-1. This scenario does not account for the rate coefficient for decay or the zero-order rate coefficient for production. 


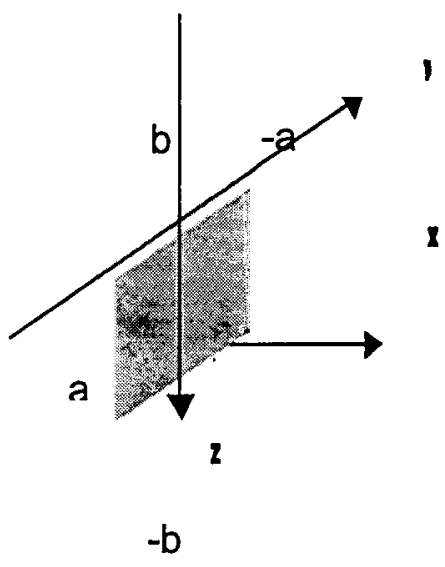

Figure 1-1. Schematic of Inlet and Solute Distribution for a Vertical Rectangular Source in the 3-D Solute Transport Analytical Solution (shown centrally located about the origin of the axes)

NOTES: The direction of flow is in the $x$-direction and the water table is located along the $y$-axis. Note that a and -a represent locations along the $y$-axis and $b$ and $-b$ are locations along the $z$ axis (the vertical axis).

\section{b) Description of Software Routine Including the Execution Environment}

F. Leij, T. Skaggs, and M. van Genuchten published the theory and applications of 3DADE (Leij et al. 1991). The paper documents the theory, assumptions, and boundary conditions used in deriving the analytical solutions and the corresponding code used to solve the analytical solution.

The executable version of 3DADE was run on the SUN Ultra Sparc workstation at the Los Alamos National Laboratory in Los Alamos, New Mexico. The solution was implemented in FORTRAN and may be complied by any standard FORTRAN 77 compiler.

\section{c) Description of Test Cases}

To ensure that the 3-DADE code calculated the analytical solution correctly, a validation problem was designed. The 3DADE analytical solution was verified using a 3-D analytical solution by Domenico and Schwartz (1990, p. 646).

$C(x, y, z, t)=\left(\frac{C_{0}}{8}\right) \operatorname{erf}\left[\frac{(x-v t)}{2 \sqrt{\alpha_{x} v t}}\right] \mid \operatorname{erf}\left\lfloor\frac{(y+Y / 2)}{2 \sqrt{\alpha_{y} x}}\right]-\operatorname{erf}\left[\frac{(y-Y / 2)}{2 \sqrt{\alpha_{y} x}}\right]\left\{\operatorname{erf}\left[\frac{(z+Z)}{2 \sqrt{\alpha_{z} x}}\right]-\operatorname{erf}\left[\frac{(z-Z)}{2 \sqrt{\alpha_{z} x}}\right]\right\}$ 
where

$v$ is the contaminant velocity

$\alpha_{x}, \alpha_{y}$, and $\alpha_{z}$ is the longitudinal dispersivity, transverse horizontal dispersivity, and transverse vertical dispersivity, respectively

$t$ is time

$Y$ and $Z$ are the source size dimensions

$x, y$, and $z$ are distances along the respective coordinate axes.

Equation I-2 was used for the test cases to ensure the validity of the 3DADE solution. Two test cases were prepared: Test Case 1 is a breakthrough curve and Test Case 2 calculates the concentrations as a function of depth.

\section{Test Case 1 (Breakthrough Case)}

Inputs for the breakthrough case:

Vertical transverse dispersivity $=0.005 \mathrm{~m}$

Horizontal transverse dispersivity $=0.005 \mathrm{~m}$

Longitudinal dispersivity $=50 \mathrm{~m}$

Source size of $3000 \mathrm{~m}$ in width and $12.5 \mathrm{~m}$ in depth $(z)$

Breakthrough Distance $=20000 \mathrm{~m}$ (in the direction of flow)

Retardation $=1.0$

Initial concentration $=1.0$

Velocity $=100 \mathrm{~m} / \mathrm{yr}$

Time $=2000 \mathrm{yr}$.

Horizontal distance $(y)=0$ (perpendicular to the flow direction)

Depth $(z)=0$ (perpendicular to the flow direction).

The results of the $3 \mathrm{DADE}$ code are compared to the solution obtained from Equation I-2 and are shown in Figure I-2. 


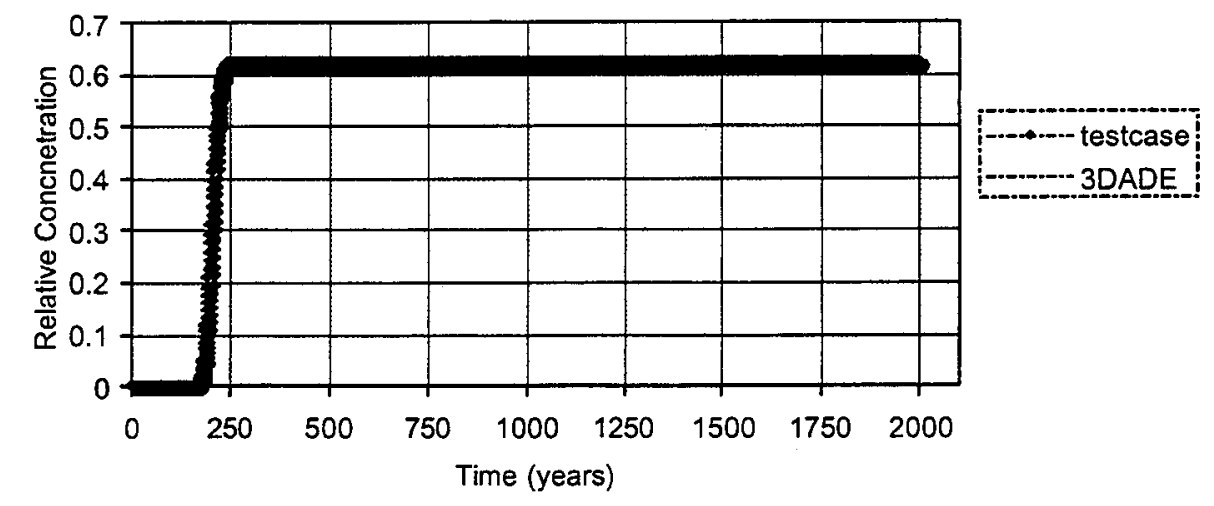

Figure 1-2. Breakthrough Test Case Comparing 3DADE and Equation 1-2 (labelled "testcase")

Figure I-2 shows that 3DADE and Equation I-2 predict very similar breakthrough curves. The input file for $3 \mathrm{DADE}$ is case2_brktr.in.

\section{Test Case 2 (Horizontal Concentrations)}

Inputs for Case 2:

Vertical transverse dispersivity $=0.005 \mathrm{~m}$

Horizontal transverse dispersivity $=0.005 \mathrm{~m}$

Longitudinal dispersivity $=50 \mathrm{~m}$

Source size of $3000 \mathrm{~m}$ in width and $12.5 \mathrm{~m}$ in depth (z)

Breakthrough Distance $=20000 \mathrm{~m}$

Retardation $=1.0$

Initial concentration $=1.0$

Velocity $=100 \mathrm{~m} / \mathrm{yr}$.

Time $=2000 \mathrm{yr}$.

Horizontal distance $(y)=-3000$ to 3000 (perpendicular to the flow direction)

Depth $(z)=0$ (perpendicular to the flow direction). 


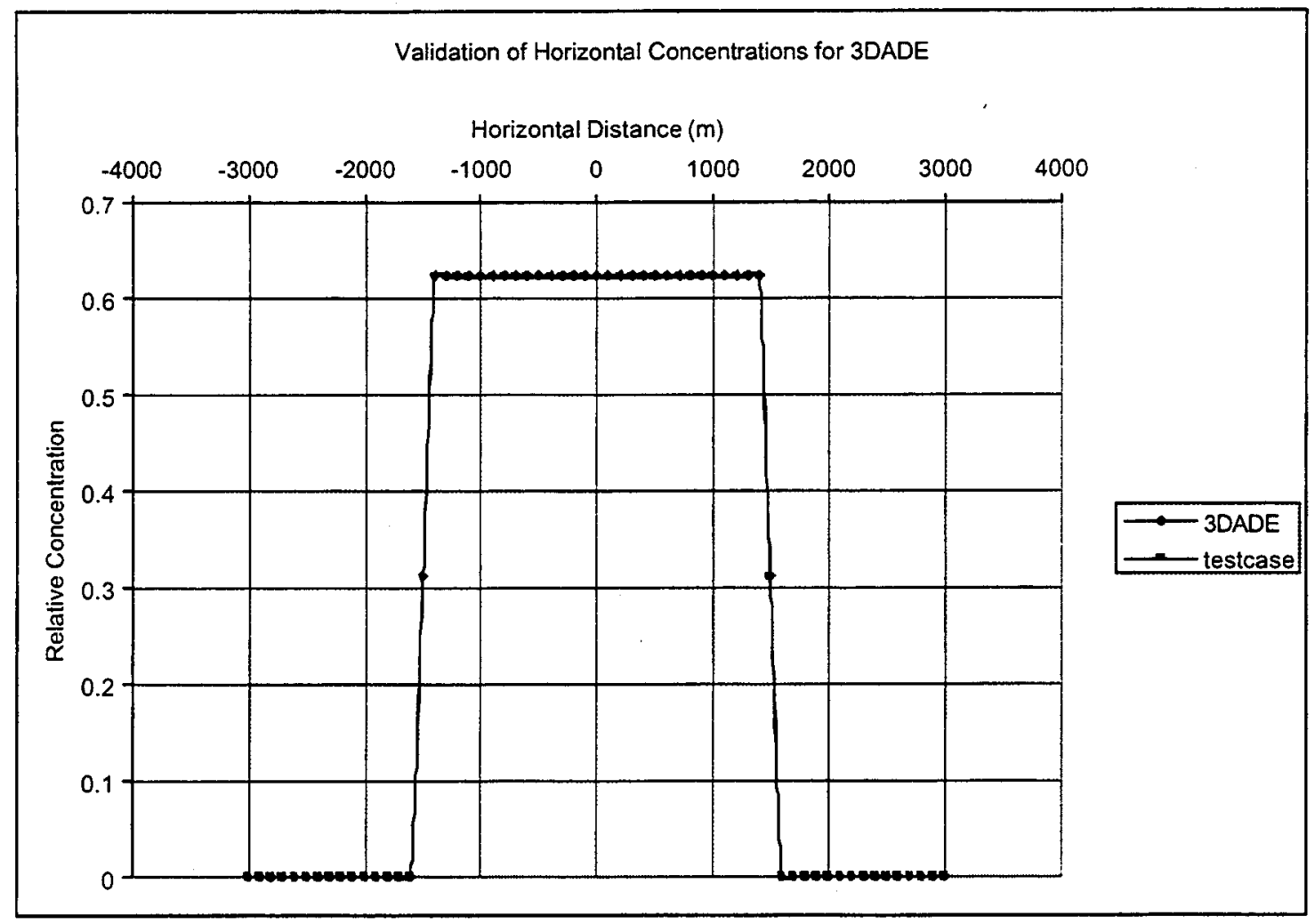

Figure 1-3. Comparison of Results from 3DADE and Equation I-2 (labelled "testcase")

Figure I-3 shows that 3DADE and Equation I-2 predict very similar predictions of concentration for horizontal spreading. The input file for $3 \mathrm{DADE}$ is case2_horiz.in.

\section{c) Range of Input Parameter Values for which Results were Verified}

The 3DADE software routine solves the 3-D advection-dispersion equation and is valid for use in this document. Test Cases 1 and 2 are representative samples. 


\section{SUPPORTING INFORMATION}

Electronic file listing:

Software routines

3DADE.for: Software routine source listing

3DADE: $\quad$ Executable for 3DADE.for

\section{Test case files}

\section{Validation_brk.xls:}

Worksheets: 1) validation_brk: output files from plume software routine and graph of breakthrough test case

2) validation_hor: output file from plume software routine and graph of the horizontal concentrations.

*case2_brktr.in: Input file for breakthrough curve test case.

case2_brktr.out: Output file for breakthrough curve test case.

*plume_casebc.in: Input file for horizontal concentration test case.

plume_casebc.out: Output file for horizontal concentration test case.

\section{REFERENCES}

Domenico, P.A. and Schwartz, F.W. 1990. Physical and Chemical Hydrogeology. New York, New York: John Wiley \& Sons Inc. TIC: 234782.

Leij, F.J.; Skaggs, T.H.; and van Genuchten, M.Th. 1991. "Analytical Solutions for Solute Transport in Three-Dimensional Semi-infinite Porous Media." Water Resources Research, 27(10), 2719-2733. Washington, D.C.: American Geophysical Union. TIC: 238367.

CRWMS M\&O, 1998, Saturated Zone Flow and Transport Expert Elicitation Project, Deliverable SL5X4AM3, Las Vegas, Nevada: CRWMS M\&O." 
Table 2a. Ratio of Discharge Areas and Peak Concentrations of Plume Cross Sections for $99 \%$ Captured Mass

\begin{tabular}{|c|c|c|}
\hline \multirow[t]{2}{*}{ Case } & \multicolumn{2}{|c|}{$\begin{array}{l}\text { Ratio of Discharge Area for } 99 \% \text { Captured Mass } \\
\text { Ratio of }\left\{\text { Peak Relative Concentration } C / C_{0}\right\}\end{array}$} \\
\hline & $18 \mathrm{~km}$ to $30 \mathrm{~km}$ & $30 \mathrm{~km}$ to $60 \mathrm{~km}$ \\
\hline 1. Large Source: $3000 \mathrm{~m} \times 10 \mathrm{~m}$ & $6.8 \times 10^{-1}(1.5)$ & $5.7 \times 10^{-1}(1.8)$ \\
\hline$A_{1}=100 \mathrm{~m}, A_{\mathrm{th}}=10 \mathrm{~m}, A_{\mathrm{lv}}=0.1 \mathrm{~m}$ & $\left\{7.4 \times 10^{-1}(1.3)\right\}$ & $\left\{6.2 \times 10^{-1}(1.6)\right\}$ \\
\hline 2. Large Source: $3000 \mathrm{~m} \times 10 \mathrm{~m}$ & $7.7 \times 10^{-1}(1.3)$ & $6.8 \times 10^{-1}(1.5)$ \\
\hline$A_{1}=100 \mathrm{~m}, A_{\mathrm{th}}=0.5 \mathrm{~m}, A_{\mathrm{iv}}=0.005 \mathrm{~m}$ & $\left\{8.0 \times 10^{-1}(1.2)\right\}$ & $\left\{7.2 \times 10^{-1}(1.4)\right\}$ \\
\hline 3. Small Source: $10 \mathrm{~m} \times 10 \mathrm{~m}$ & $7.0 \times 10^{-1}(1.4)$ & $6.9 \times 10^{-1}(1.4)$ \\
\hline$A_{1}=100 \mathrm{~m}, A_{\mathrm{ln}}=10 \mathrm{~m}, A_{\mathrm{lv}}=0.1 \mathrm{~m}$ & $6.0 \times 10^{-1}(1.7)$ & $\left\{5.0 \times 10^{-1}(2.0)\right\}$ \\
\hline 4. Small Source: $10 \mathrm{~m} \times 10 \mathrm{~m}$ & $6.2 \times 10^{-1}(1.6)$ & $5.3 \times 10^{-1}(1.9)$ \\
\hline$A_{l}=100 \mathrm{~m}, A_{\mathrm{th}}=0.5 \mathrm{~m}, A_{\mathrm{v}}=0.005 \mathrm{~m}$ & $\left\{6.2 \times 10^{-1}(1.6)\right\}$ & $\left\{5.0 \times 10^{-1}(2.0)\right\}$ \\
\hline
\end{tabular}

Table 2b. Ratio of Discharge Areas and Peak Concentrations of Plume Cross Sections for $90 \%$ Captured Mass

\begin{tabular}{|c|c|c|}
\hline \multirow[t]{2}{*}{ Case } & \multicolumn{2}{|c|}{$\begin{array}{l}\text { Ratio of Discharge Area for } 90 \% \text { Captured Mass } \\
\text { Ratio of }\left\{\text { Peak Relative Concentration } C / C_{0}\right\}\end{array}$} \\
\hline & $18 \mathrm{~km}$ to $30 \mathrm{~km}$ & $30 \mathrm{~km}$ to $60 \mathrm{~km}$ \\
\hline 1. Large Source: $3000 \mathrm{~m} \times 10 \mathrm{~m}$ & $7.0 \times 10^{-1}(1.4)$ & $5.9 \times 10^{-1}(1.7)$ \\
\hline$A_{t}=100 \mathrm{~m}, A_{\mathrm{th}}=10 \mathrm{~m}, A_{\mathrm{tv}}=0.1 \mathrm{~m}$ & $\left\{7.4 \times 10^{-1}(1.3)\right\}$ & $\left\{6.2 \times 10^{-1}(1.6)\right\}$ \\
\hline 2. Large Source: $3000 \mathrm{~m} \times 10 \mathrm{~m}$ & $7.9 \times 10^{-1}(1.3)$ & $7.1 \times 10^{-1}(1.4)$ \\
\hline$A_{l}=100 \mathrm{~m}, A_{\mathrm{th}}=0.5 \mathrm{~m}, A_{\mathrm{ty}}=0.005 \mathrm{~m}$ & $\left\{8.0 \times 10^{-1}(1.2)\right\}$ & $\left\{7.2 \times 10^{-1}(1.4)\right\}$ \\
\hline 3. Small Source: $10 \mathrm{~m} \times 10 \mathrm{~m}$ & $6.2 \times 10^{-1}(1.6)$ & $5.4 \times 10^{-1}(1.8)$ \\
\hline$A_{1}=100 \mathrm{~m}, A_{\mathrm{th}}=10 \mathrm{~m}, A_{\mathrm{tv}}=0.1 \mathrm{~m}$ & $\left\{5.6 \times 10^{-1}(1.8)\right\}$ & $\left\{6.0 \times 10^{-1}(1.7)\right\}$ \\
\hline 4. Small Source: $10 \mathrm{~m} \times 10 \mathrm{~m}$ & $6.1 \times 10^{-1}(1.6)$ & $5.2 \times 10^{-1}(1.9)$ \\
\hline$A_{l}=100 \mathrm{~m}, A_{\mathrm{th}}=0.5 \mathrm{~m}, A_{\mathrm{lv}}=0.005 \mathrm{~m}$ & $\left\{6.3 \times 10^{-1}(1.6)\right\}$ & $\left\{5.0 \times 10^{-1}(2.0)\right\}$ \\
\hline
\end{tabular}


Analyses for Disposal of Commercial and DOE Waste Inventories at Yucca Mountain - Input to Final Environmental Impact Statement and Site Suitability Evaluation

Table 6-1 Peak Dose and Year of Peak Dose by Scenario for Various Performance Periods: (a) Peak Mean Annual Dose; (b) Peak $95^{\text {th }}$ Annual Dose

\begin{tabular}{|c|c|c|c|c|c|c|c|}
\hline \multicolumn{8}{|c|}{ Mean Annual Dose (mrem/yr) } \\
\hline \multirow{2}{*}{ Case } & \multirow{2}{*}{ Model File } & \multicolumn{2}{|c|}{10,000 yr Peak } & \multicolumn{2}{|c|}{100,000 yr Peak } & \multicolumn{2}{|c|}{$1,000,000$ yr Peak } \\
\hline & & Value & Year & Value & Year & Value & Year \\
\hline 70,000 MTHM, HTOM & SE01_006nm6 & $9.7 \mathrm{E}-05$ & 4,875 & $1.2 \mathrm{E}-01$ & 99.500 & 152.5 & 476,000 \\
\hline 70.000 MTHM. LTOM & SE01_007nm6 & $1.1 \mathrm{E}-05$ & 3.437 .5 & 8.5E-02 & 99.500 & 122.2 & 476,000 \\
\hline Module 1. HTOM & SE01_010nm6 & 2.7E-05 & $4,937.5$ & $1.6 \mathrm{E}-01$ & 100,000 & 237.9 & 476,000 \\
\hline Module 2. HTOM & SE01_012nm6 & $6.6 \mathrm{E}-04$ & 2,875 & $6.6 \mathrm{E}-04$ & 2,875 & 3.3E-01 & 208.000 \\
\hline Igneous Activity, HTOM & SE01_001im5 & $1.0 \mathrm{E}-01$ & 312.5 & $1.0 E-01$ & 312.5 & & \\
\hline Igneous Activity, LTOM & SE01_002im5 & $1.0 \mathrm{E}-01$ & 312.5 & $1.0 E-01$ & 312.5 & & \\
\hline Igneous Activity, HTOM (Intrusive Only) & SE01_00tim5 & 4.3E-04 & 10.000 & $2.1 \mathrm{E}-02$ & 48.000 & & \\
\hline Igneous Activity, LTOM (Intrusive Only) & SE01_002im5 & $5.0 E-04$ & 10,000 & $2.8 \mathrm{E}-02$ & 48,000 & & \\
\hline Igneous Activity, HTOM (Eruptive Only) & SE01_001im5 & $1.0 \mathrm{E}-01$ & 312.5 & $1.0 E-01$ & 312.5 & & \\
\hline Igneous Activity, LTOM (Enuptive Only) & SE01_002im5 & $1.0 \mathrm{E}-01$ & 312.5 & $1.0 \mathrm{E}-01$ & 312.5 & & \\
\hline Human Intrusion $30 \mathrm{k}-\mathrm{yr}$ Event, HTOM & SE01_001hm6 & & & $1.7 \mathrm{E}-03$ & 30.562 .5 & $2.3 E-03$ & 108,000 \\
\hline Human Intrusion 100-yr Event, HTOM & SEO $1002 \mathrm{hm} 6$ & $4.8 \mathrm{E}-03$ & 875 & $4.8 \mathrm{E}-03$ & 875 & $4.8 \mathrm{E}-03$ & 875 \\
\hline
\end{tabular}

\begin{tabular}{|c|c|c|c|c|c|c|c|}
\hline \multicolumn{8}{|c|}{ 95th Percentile Annual Dose (mrem/yr) } \\
\hline \multirow{2}{*}{ Case } & \multirow{2}{*}{ Model File } & \multicolumn{2}{|c|}{10,000 yr Peak } & \multicolumn{2}{|c|}{100,000 yr Peak } & \multicolumn{2}{|c|}{$1,000,000$ yr Peak } \\
\hline & & Value & Year & Value & Year & Value & Year \\
\hline 70,000 MTHM, HTOM & SE01_006nm6 & $9.2 \mathrm{E}-04$ & 4.937 .5 & $4.0 \mathrm{E} \cdot 02$ & 99.500 & 618.0 & 408,000 \\
\hline 70.000 MTHM, LTOM & SE01_007nm6 & 8.6E-05 & 5,000 & 3.4E-02 & 100,000 & 513.2 & 408,000 \\
\hline Module 1, HTOM & SE01_010nm6 & $1.8 \mathrm{E}-04$ & 4125 & 7.9E-02 & 100,000 & 976.7 & 476.000 \\
\hline Module 2. HTOM' & SE01_012nm6 & $0.0 E+00$ & N/A & $1.3 \mathrm{E}-03$ & 100.000 & 1.5 & 208.000 \\
\hline Igneous Activity, HTOM & SE01_001im5 & 4.1E-01 & 312.5 & 4.1E-01 & 312.5 & & \\
\hline Igneous Activity, LTOM & SE01_002im5 & 4.1E-01 & 312.5 & 4.1E-01 & 312.5 & & \\
\hline Igneous Activity, HTOM (Intrusive Only) & SE01_001im5 & $2.9 \mathrm{E}-04$ & 9.750 & $5.2 \mathrm{E}-02$ & 100,000 & & \\
\hline Igneous Activity, LTOM (Intrusive Only) & SEQ1_002im5 & $3.1 \mathrm{E}-04$ & 9,875 & 3.3E-02 & 48.000 & & \\
\hline Igneous Activity, HTOM (Eruptive Only) & SE01_001im5 & 4.1E-01 & 312.5 & $4.1 E-01$ & 312.5 & & \\
\hline Igneous Activity, LTOM (Eruptive Only) & SE01_002im5 & 4.1E-01 & 312.5 & 4.1E-01 & 312.5 & & \\
\hline Human Intrusion 30k-yr Event, HTOM & SE01_001hm6 & & & 4.5E-03 & 38,500 & 4.5E-03 & 38,500 \\
\hline Human Intrusion 100-yr Event. HTOM & SE01 $002 \mathrm{hm} 6$ & 8.9E-03 & $2,687.5$ & $8.9 E-03$ & $2,687.5$ & $8.9 E-03$ & 2.687 .5 \\
\hline \multicolumn{8}{|l|}{ N/A $=$ Not Applicable } \\
\hline th hiohest value is 0 mromive & & & & & & & \\
\hline
\end{tabular}

\subsubsection{Annual Dose Calculated for the Low-Temperature Operating Mode}

Figure 6-3 displays representations of the mean annual dose results of the 300 probabilistic simulations for the LTOM (approximately $45 \mathrm{MTHM}$ /acre) for the 70,000 MTHM inventory at the RMEI location ( $18 \mathrm{~km}$ downgradient from the repository) for 1,000,000 years after repository closure. Because Figure 6-3 shows little difference between the annual dose histories calculated for the HTOM and the LTOM, the remaining scenarios, other than the igneousactivity scenario, were only simulated for the HTOM.

Figure 6-6 displays the results of the 300 probabilistic simulations of the $70,000-\mathrm{MTHM}$ case, LTOM, at the RMEI location $(\sim 18 \mathrm{~km})$ downgradient from the repository for $1,000,000$ years after repository closure. This figure displays the results for each realization and the $5^{\text {th }}$ and $95^{\text {th }}$ percentiles, and the mean and median of these simulations. 
Analyses for Disposal of Commercial and DOE Waste Inventories at Yucca Mountain - Input to Final Environmental Impact Statement and Site Suitability Evaluation

Figure 6-17 presents the mean activity concentrations of gross alpha activity and total radium $\left({ }^{226} \mathrm{Ra}\right.$ plus $\left.{ }^{228} \mathrm{Ra}\right)$ in the representative volume of groundwater for the 70,000 MTHM case, HTOM. The concentrations are calculated for a representative volume of water of 3,000 acrefeet at the same location as the RMEI at the accessible environment as described in 40 CFR Part 197.30 and Part 197.31 ([DIRS 155216], p. 32134 to 32135). Naturally occurring background radionuclide concentrations are not included because the calculated values are negligible compared to background concentrations up to 100,000 years postclosure. Figure 6-18 presents the same information for the LTOM.

Figure 6-19 presents the mean dose to critical organs for ${ }^{99} \mathrm{Tc},{ }^{14} \mathrm{C}$, and ${ }^{129} \mathrm{I}$, the prominent beta and photon-emitting radionuclides (CRWMS M\&O 2000 [DIRS 153246], Section 4.1.5, p. 4-17) for the 70,000 MTHM inventory, HTOM, for the 1,000,000 performance period. Figure 6-20 presents the mean dose to critical organs for ${ }^{99} \mathrm{Tc},{ }^{14} \mathrm{C}$, and ${ }^{129} \mathrm{I}$ for the $70,000 \mathrm{MTHM}$ inventory, LTOM, for the $1,000,000$ performance period.

The results developed for the groundwater-protection standard are tabulated in Table 6-2, which shows the peak mean gross alpha activity by scenario for various performance periods; Table 6-3 which shows peak total radium concentration by scenario for various performance periods; and Table 6-4 which shows the peak dose to critical organs in 10,000 years for ${ }^{99} \mathrm{Tc},{ }^{14} \mathrm{C}$, ${ }^{129} \mathrm{I}$, and the total of all beta- and photon-emitting radionuclides.

Table 6-2 Peak Mean Gross Alpha Activity by Scenario for Various Performance Periods

\begin{tabular}{|c|c|c|c|c|c|c|c|}
\hline \multicolumn{8}{|l|}{ Mean Alpha Activity (pCi/L) } \\
\hline \multirow{2}{*}{ Case } & \multirow[t]{2}{*}{ Model File } & \multicolumn{2}{|c|}{10,000 yr Peak } & \multicolumn{2}{|c|}{100,000 yr Peak } & \multicolumn{2}{|c|}{$1,000,000$ yr Peak } \\
\hline & & w/o bekgind & w/ bckgend & w/o bekgrnd & w/ bekgrnd & w/o bckgind & w/ bckgrnd \\
\hline 70.000 MTHM, HTOM & SE01_006nm6 & $1.8 \mathrm{E}-08$ & $4.0 \mathrm{E}-01$ & 1.7E-02 & $4.2 \mathrm{E}-01$ & 17.7 & 18.1 \\
\hline 70.000 MTHM, LTOM & SE01_007nm6 & 3.3E-08 & 4.0E-01 & $1.0 E-02$ & 4.1E-01 & 14.2 & 14.6 \\
\hline Module 1, HTOM & SE01_010nm6 & 3.3E-08 & $4.0 \mathrm{E}-01$ & 2.3E-02 & 4.2E-01 & 27.7 & 28.1 \\
\hline Module 2, HTOM & SE01_012nm6 & $2.2 E-10$ & 4.0E-01 & 4.2E-05 & 4.0E-01 & $3.9 \mathrm{E}-02$ & 4.4E-01 \\
\hline Human Intrusion 30k-yr Event. HTOM & SE01_001hm6 & N/A & & $1.8 E-04$ & 4.0E-01 & 3.1E-04 & $4.0 E-01$ \\
\hline Human Intrusion 100.yr Event. HTOM & SE0 1 $002 \mathrm{hm} 6$ & 3.7E-05 & 4.0E-01 & $3.6 E-04$ & 4.0E-01 & $3.6 \mathrm{E}-04$ & 4.0E-01 \\
\hline \multicolumn{8}{|c|}{$\begin{array}{l}\text { Background Alpha Activity Concentration is } 0.4 \mathrm{pCi} / \mathrm{L} \\
\text { Mean Gross Alpha Activity is Not Available for Volcanic Scenarios } \\
\text { N/A = Not Applicable }\end{array}$} \\
\hline
\end{tabular}

Table 6-3 Peak Total Radium Concentration by Scenario for Various Performance Periods

\begin{tabular}{|c|c|c|c|c|c|c|c|}
\hline \multicolumn{8}{|c|}{ Total Radium (226Ra and 228Ra) Concentration (pCi/L) } \\
\hline \multirow{2}{*}{ Case } & \multirow{2}{*}{ Model File } & \multicolumn{2}{|c|}{10,000 yr Peak } & \multicolumn{2}{|c|}{100,000 yr Peak } & \multicolumn{2}{|c|}{$1,000,000$ yr Peak } \\
\hline & & wio bekgrnd & w/ bckgrnd & w/o bckgrnd & w/ bckgrnd & w/o bekgind & W/ bekgrnd \\
\hline 70,000 MTHM, HTOM & SE01 $006 n m 6$ & $1.1 \mathrm{E}-11$ & 1.0 & $2.4 \mathrm{E} \cdot 05$ & 1.0 & $3.3 \mathrm{E}-01$ & 1.4 \\
\hline 70,000 MTHM, LTOM & SE01_007nm6 & $2.4 \mathrm{E}-12$ & 1.0 & 2.7E-05 & 1.0 & 2.7E-01 & 1.3 \\
\hline Module 1, HTOM . & SE01_010nm6 & 3.3E-10 & 1.0 & 4.0E-05 & 1.0 & $6.7 \mathrm{E}-01$ & 1.7 \\
\hline Module 2. HTOM & SE01-012nm6 & $6.7 E-13$ & 1.0 & $6.8 \mathrm{E}-09$ & 1.0 & $1.6 \mathrm{E}-03$ & 1.0 \\
\hline Human Intrusion 30k-yr Event, HTOM & SE01-001 hm6 & \multicolumn{2}{|c|}{ N/A } & $2.4 E-07$ & 1.0 & $3.8 \mathrm{E}-07$ & 1.0 \\
\hline Human Intrusion 100-yr Event. HTOM & SE01 $002 \mathrm{hm} 6$ & 4.8E-09 & 1.0 & 2.4E-07 & 1.0 & $3.8 E-07$ & 1.0 \\
\hline $\begin{array}{l}\text { Background Radium Activity Concentr } \\
\text { Total Radium Concentration is Not Ava } \\
\text { N/A = Not Applicable }\end{array}$ & on is $1.04 \mathrm{pCi} / \mathrm{L}$ & enarios & & & & & \\
\hline
\end{tabular}




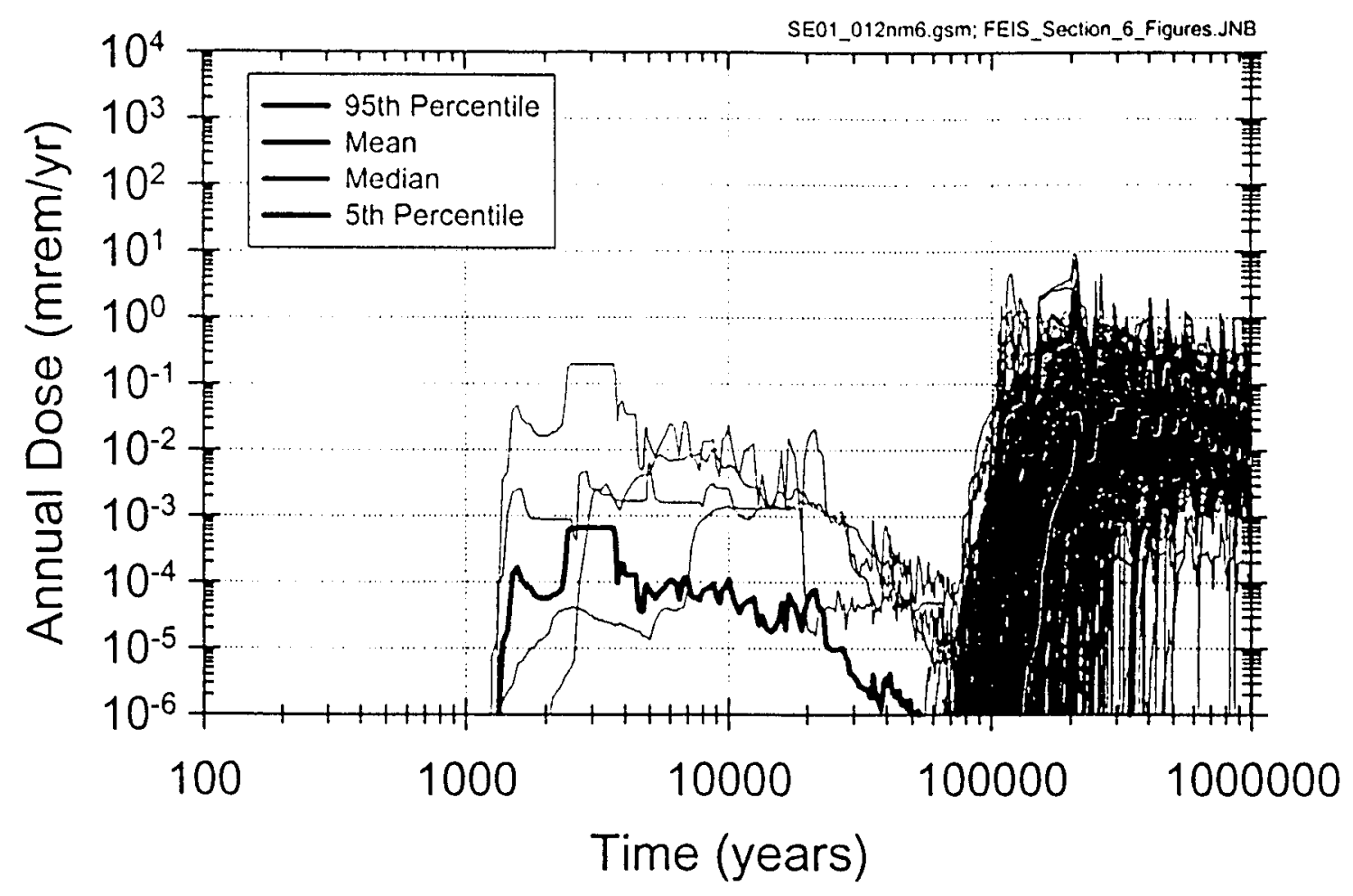

Figure 6-8 Annual Dose versus Time for 300 Probabilistic Simulations of the Module 2 Expanded Inventory for the HTOM at the RMEI Location Downgradient from a Repository. The Figure Displays the Results for Each Simulation and the $5^{\text {th }}$ and $95^{\text {th }}$ Percentiles, and the Mean and Median of these Simulations. 


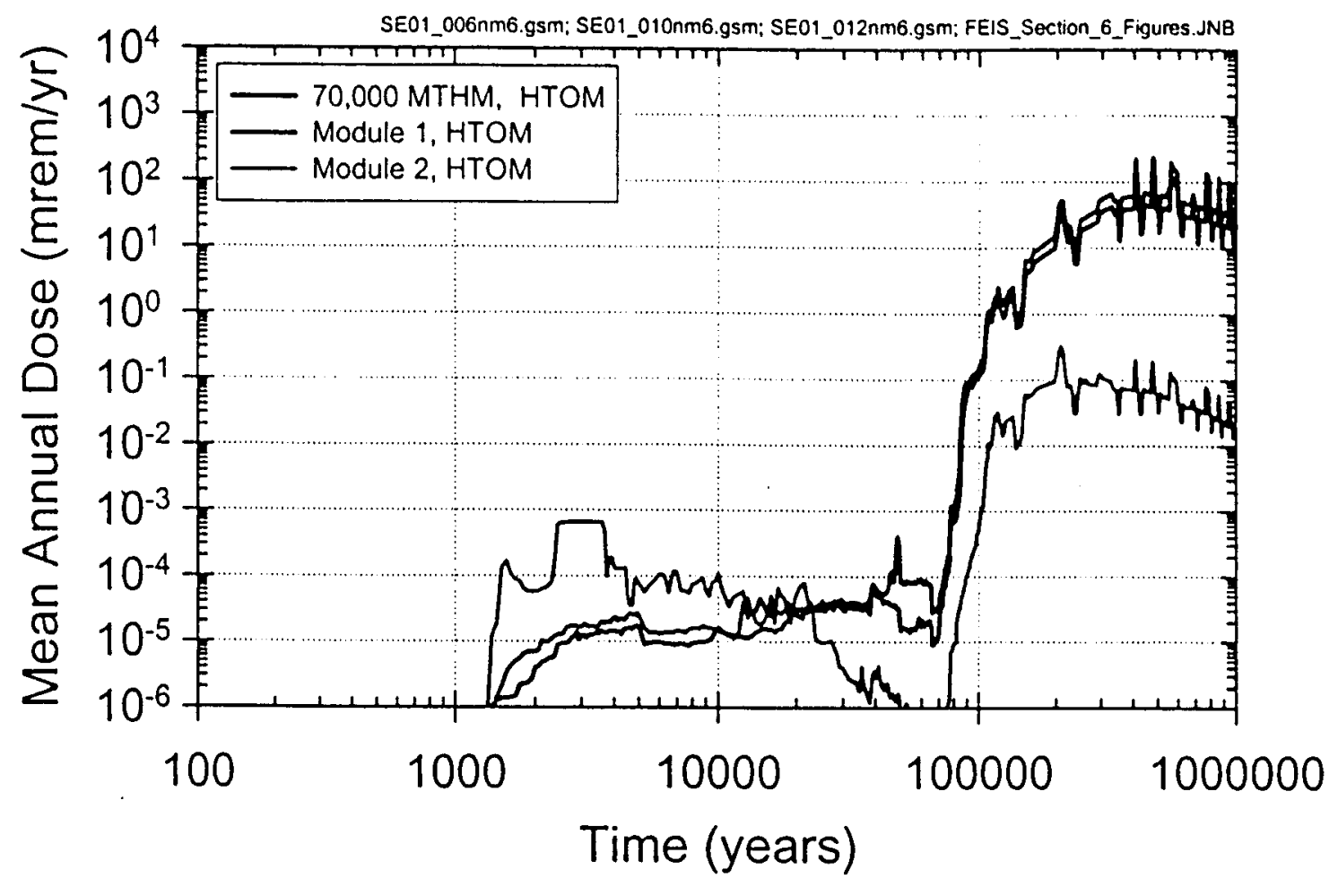

Figure 6-9 Comparison Plot of the Mean Annual Dose versus Time for HTOM for the 70,000-MTHM, Module 1 and Module 2 Inventories at the RMEI location Downgradient from a Repository 


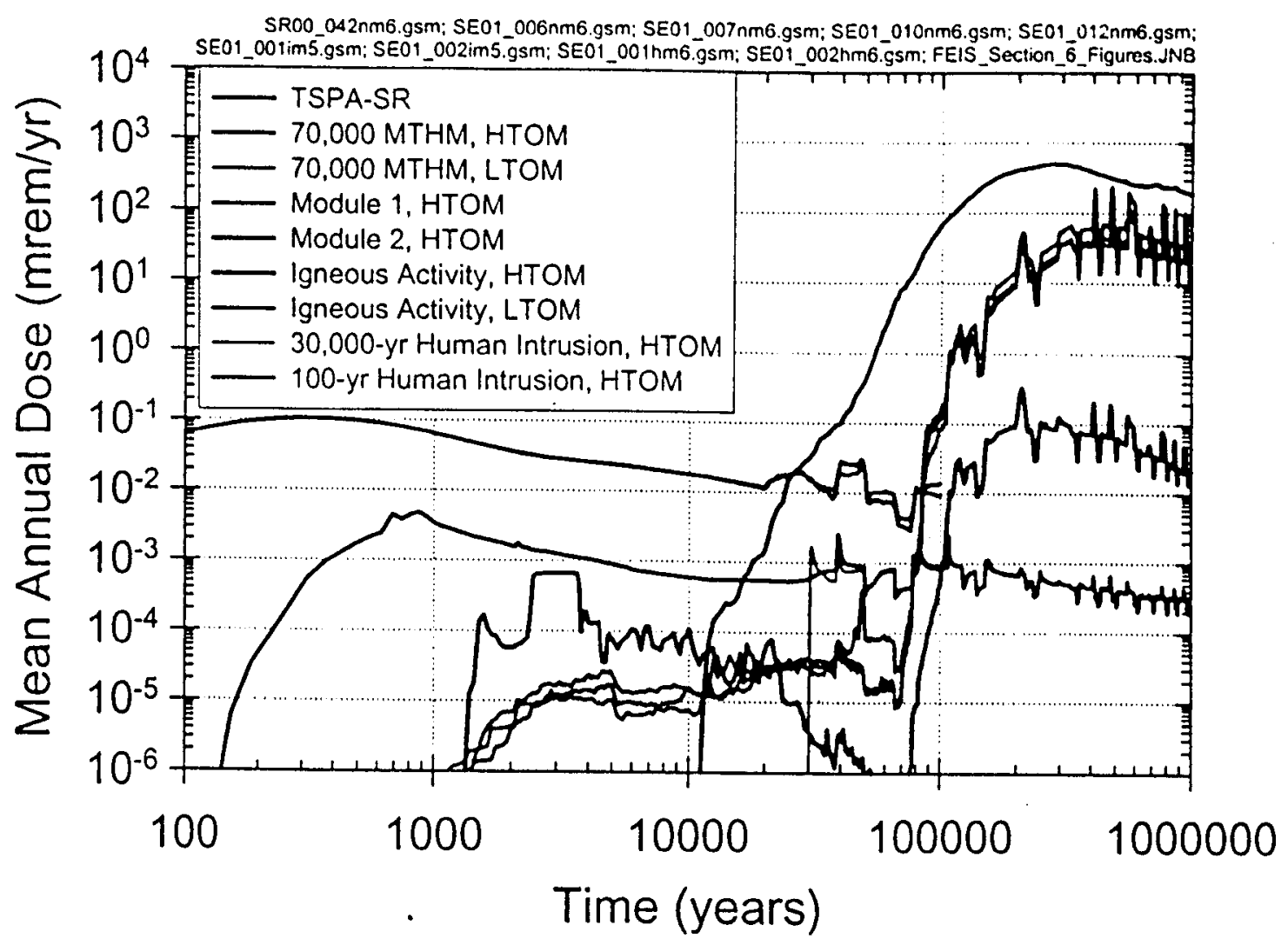

Figure 6-15 Comparison of the Annual Dose versus Time for the 70,000 MTHM Inventory, HTOM and LTOM, the Module 1 Inventory, HTOM, the Module 2 Inventory, HTOM, the IgneousActivity Scenario, HTOM and LTOM, the 30,000-yr and 100-yr Human-Intrusion Scenarios, HTOM, and the TSPA-SR Case, HTOM 